WILSON MITSUO TATAGIBA KUWABARA

\title{
PARTICIPAÇÃO DO ESTRESSE DE RETÍCULO \\ ENDOPLASMÁTICO NO PROCESSO DE MORTE \\ CELULAR EM NEUTRÓFILOS DE RATOS DIABÉTICOS
}

Tese apresentada ao Programa de Pós-Graduação em Fisiologia Humana do Instituto de Ciências Biomédicas da Universidade de São Paulo, para obtenção do Título de Mestre em Ciências. 


\section{WILSON MITSUO TATAGIBA KUWABARA}

\section{PARTICIPAÇÃO DO ESTRESSE DE RETÍCULO \\ ENDOPLASMÁTICO NO PROCESSO DE MORTE \\ CELULAR EM NEUTRÓFILOS DE RATOS DIABÉTICOS}

Tese apresentada ao Programa de Pós-Graduação em Fisiologia Humana do Instituto de Ciências Biomédicas da Universidade de São Paulo, para obtenção do Título de Mestre em Ciências.

Área de Concentração:

Fisiologia Humana

Orientadora:

Dra. Tatiana Carolina Alba Loureiro

Versão original 
DADOS DE CATALOGAÇÅ̃O NA PUBLICAÇÃO (CIP)

Serviço de Biblioteca e Informação Biomédica do

Instituto de Ciências Biomédicas da Universidade de São Paulo

reproduçăo năo autortzada pelo autor

Kuwabara, Wilson Mitsuo Tatagiba.

Participaçäo do estresse de reticulo endoplasmático no processo de morte celular de neutrófilos de ratos diabéticos / Wilson Mitsuo

Tatagiba Kuwabara. - Säo Paulo, 2013.

Orientador: Profa. Dra. Tatiana Carolina Alba Loureiro.

Dissertaçäo (Mestrado) - Universidade de Säo Paulo. Instituto de Ciências Biomédicas. Departamento de Fisiologia e Biofísica. Área de concentraçäo: Fisiologia Humana. Linha de pesquisa: Metabolismo e função de neutrófilos.

Versäo do título para o inglês: The role of the endoplasmatic reticulum in the process of death of neutrophilis from diabetic rats.

1. Neutrófilos 2. Diabetes mellitus 3. Retículo endoplasmático I. Loureiro, Profa. Dra. Tatiana Carolina Alba II. Universidade de São Paulo. Instituto de Ciências Biomédicas. Programa de Pós-Graduação em Fisiologia Humana III. Título. 
UNIVERSIDADE DE SÃO PAULO

INSTITUTO DE CIÉNCIAS BIOMÉDICAS

Candidato(a): $\quad$ Wilson Mitsuo Tatagiba Kuwabara.

Título da Dissertação: $\quad$ Participação do estresse de retículo endoplasmático no processo de morte celular de neutrófilos de ratos diabéticos.

Orientador(a): $\quad$ Profa. Dra. Tatiana Carolina Alba Loureiro.
A Comissão Julgadora dos trabalhos de Defesa da Dissertação de Mestrado, em sessão pública realizada a .J. ................., considerou
( ) Aprovado(a)
( ) Reprovado(a)
Examinador(a): Assinatura:
Nome:
Instituição:
Examinador(a): Assinatura:
Nome:
Instituição:
Presidente: Assinatura:
Nome:
Instituição:




\section{Certificado}

Certificamos que o protocolo registrado sob $n^{\circ} \mathbf{1 0 9}$ nas fls. 108 do livro 02 para uso de animais em experimentação, sob a responsabilidade do Prof(a) Dr(a)) Tatiana Carolina Alba Loureiro, Coordenador (a) da Linha de pesquisa "Participação do stress de retículo no processo de morte celular em neutrófilos de ratos diabéticos" do qual participam o(s) aluno(s) Wilson Mitsuo Tagagiba Kuwabara e o pesquisador, Rui Curi, está de acordo com os Princípios Éticos de Experimentação Animal adotado pela Sociedade Brasileira de Ciência de Animais de Laboratório (SBCAL) e foi aprovado pela COMISSÃO DE ÉTICA NO USO DE ANIMAIS (CEUA) em 19.09.2011, com validade de 3 anos.

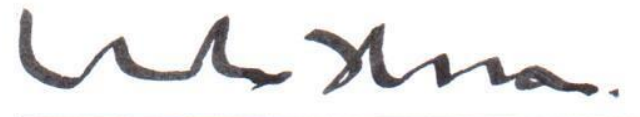

Prof.Dr.WOTHAN TAVARES DE LIMA Coordenador CEUA - ICB/USP
São Paulo, 22 de setembro de 2011.

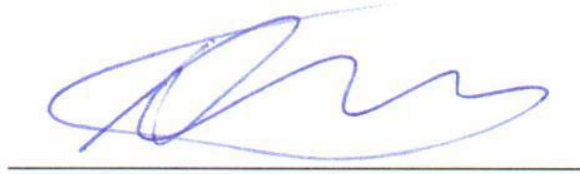

Prof. Dr. ARIEL MARIANO SILBER Secretário CEUA - ICB/USP 


\section{Dedico este trabalho,}

Primeiramente à Deus pela oportunidade, pelas condições e pela constante ajuda.

Aos meus pais, carmen e Wilson, por estarem sempre ao meu lado me apoiando e me incentivando a ser melhor e a fazer o melhor. Pela paciência ininterrupta, pelas orações, pelo amor... pela vida.

Aos meus irmãos, Mayumi e Yoíti, por receberem sempre de braços abertos esse irmão muitas vezes ausente.

Aos grandes companheiros de jornada, Bruno Micheloni, caroline Mendes, Claudia Hayashi, Erlando Schmidt, Leandro Santoro, Rafael Prévide, por estarem sempre presentes na hora de um conselho, de um abraço on de uma simples conversa. Pela paciência, pela compreensão, pela ajuda e pelo interesse em minha vida. Pela amizade.

À Tatí, pela minha construção e formcação profissional. Pela infinita dedicação, paciêncía, compreensão e orientação. Pela liberdade de expressão, pelo incentivo e acima de tudo pela amizade. 
À Profa. Dra. Tatiana Carolina Alba Loureiro por ter me ensinado e me guiado desde sempre. Pelo exemplo de dedicação e amor a pesquisa, pelo constante incentivo e principalmente pelo companherismo e amizade nessa complicada jornada.

Ao Prof. Dr. Rui Curi pelas aulas da graduação que me incentivaram a procurar a pesquisa e por me receber de braços abertos em seu laboratório. Pelo incentivo e apoio.

Aos meus pais, pelo suporte psicológico e também financeiro.

Aos amigos do GRUI que me ajudaram e ensinaram muito.

À FAPESP pelo suporte financeiro. 
"Estamos na situação de uma criancinha que entra em uma imensa biblioteca, repleta de livros em muitas línguas. A criança sabe que alguém deve ter escrito aqueles livros, mas não sabe como. Não compreende as línguas em que foram escritos. Tem uma pálida suspeita de que a disposição dos livros obedece a uma ordem misteriosa, mas não sabe qual ela é’. 


\section{RESUMO}

KUWABARA, W. M. T. Participação do estresse de retículo endoplasmático no processo de morte celular de neutrófilos de ratos diabéticos. 2013. 90 f. Dissertação (Mestrado em Fisiologia Humana) - Instituto de Ciências Biomédicas, Universidade de São Paulo, São Paulo, 2013.

O retículo endoplasmático (RE) vem ganhando evidência quando se trata de morte celular. Esta organela pode entrar em estresse devido a má formação de proteínas, falta de ATP, perturbações da sinalização de cálcio e alterações no estado redox. $\mathrm{O}$ acúmulo de proteínas mal formadas inicia a ativação da cascata de sinalização conhecida como o Unfolded Protein Response (UPR), desencadeando a ativação de Inositol-Requiring kinase la (IRE1a), doublestranded RNA-activated protein kinase-like ER kinase (PERK) e Activating transcription factor 6 (ATF6) com a finalidade de manter a homeostasia do RE. Porém, quando o estímulo do estresse perdura por muito tempo e não é resolvido, a UPR pode ativar genes que conduzem à morte celular. A hiperglicemia, presente no diabetes mellitus, pode causar estresse de RE em vários tipos celulares, como células $\beta$ pancreáticas, osteoblastos e cardiomiócitos. Assim, este estudo teve como objetivo investigar o possível envolvimento do estresse do retículo no processo de morte celular em neutrófilos de ratos diabéticos. O estresse de retículo foi avaliado pela expressão de genes-chave: GRP78, IRE-1, Perk, ATF-6 por PCR tempo real; pelo conteúdo de proteínas relacionadas à via PERK: PERK, eIF2a, peIF2a, ATF4, CHOP e GADD34; pelo conteúdo de pJNK, uma proteína relacionada à morte celular que é ativada pela via do IRE1 $\alpha$; pelo o conteúdo do ATF6 e pelo splicing de XBP1, resultante da atividade de IRE1 $\alpha$. Além disso, foi avaliada a expressão gênica de proteínas da MAM relacionadas à associação entre o RE e mitocôndria, Mitofusina 2, GRP75 e PACS2. A atividade de caspase 3 por espectrofluorimetria e a produção de espécies reativas de oxigênio (EROs) por quimioluminescência também foram avaliados. Observou-se maior expressão de GRP78 (BIP) em neutrófilos do grupo controle estimulado com PMA e maior expressão de IRE1 $\alpha$ nos neutrófilos dos grupos diabético e controle estimulados. No entanto, o aumento do IRE1 $\alpha$ também foi observado em neutrófilos não estimulados do grupo diabético. Este mesmo padrão foi observado na expressão do gene CHOP. O conteúdo de peIF $2 \alpha$ foi maior em neutrófilos do grupo controle sem estímulo e as outras proteínas da via da PERK não se mostraram alteradas. Expressão gênica das proteínas da MAM foi maior em neutrófilos do grupo controle após estímulo com PMA. O conteúdo de CHOP, bem como o de pJNK, apresentaram-se aumentados em neutrófilos do grupo diabético. Finalmente, a atividade da caspase 3 e a razão Bax/Bcl2 estão maiores em neutrófilos do grupo diabético estimulados com PMA. Em resumo, nosso estudo revelou que os neutrófilos de ratos diabéticos quando estimulados com PMA apresentam uma maior suscetibilidade à morte devido à ativação de IRE1a e subsequente fosforilação de JNK, redução na interação mitocôndria-RE na MAM e aumento da atividade da caspase-3. Concluímos também que estas alterações não foram devido as EROs, pois tanto neutrófilos de animais controle e diabético apresentam o mesmo perfil de produção dessas espécies quando estimulados com PMA. Dentre os resultados apresentados, neutrófilos provenientes de animais controle parecem estar protegidos do estresse de RE por apresentar maior expressão de GRP78 e das proteínas da MAM.

Palavras-chave: Neutrófilos. Estresse de retículo endoplasmático. Diabetes melittus. MAM. Caspase 3. 


\section{ABSTRACT}

KUWABARA, W. M. T. The role of the endoplasmatic reticulum in the process of death of neutrophils from diabetic rats. 2013. 90 p. Masters thesis (Human Physiology) - Instituto de Ciências Biomédicas, Universidade de São Paulo, São Paulo, 2013.

Endoplasmic reticulum (ER) has been gaining evidence when it comes to cell death. This organelle may go under stress conditions due to changes in protein formation, lack of ATP, disturbances in calcium signaling and alterations in the redox state. The accumulation of unfolded proteins initiates the activation of the Unfolded Protein Response (UPR). Currently, it is well established that the ER stress response is due to activation of three ER components: Inositol-Requiring kinase $1 \alpha$ (IRE1 $\alpha)$, double-stranded RNA-activated protein kinase-like ER kinase (PERK) and Activating transcription factor 6 (ATF6). The UPR may resolve the ER stress by upregulating genes responsible to maintain the ER homeostasis; or it can activate genes that lead to the cell death when the ER disbalance is not solved. Hyperglycemia, one of many symptoms observed is Diabetes, may cause ER stress in various types of cells, for instance, pancreatic $\beta$-cells, osteoblasts and cardiomiocytes. Thus, this study aims to investigate the possible involvement of the ER stress in the process of cell death in neutrophils from diabetic rats. ER stress was evaluated by the expression of key genes: GRP78 (Bip), IRE-1, PERK, ATF-6 by PCR real time; the content of proteins related to the PERK pathway: PERK, eIF2 $\alpha$, peIF2 $\alpha$, ATF4, CHOP and GADD34; the content o pJNK, a protein related to cell death that is activated by IRE1 $\alpha$ pathway; the content of ATF6 and SXBP1 resulted from the IRE1 $\alpha$ activity. Also, the gene expression of MAM proteins related to the association between ER and mitochondria, Mitofusin 2, GRP75 and PACS2, were evaluated. MAM is related to the ER homeostasis and is very importat for calcium and ATP exechange between these twoorganelles. Finally, activity of caspases 3 by spectrofluorimetry and ROS production by chemoluminescence, using luminol, were measured. We observed higher expression of GRP78 (Bip) in the control group and higher expression of IRE1 $\alpha$ in the diabetic and control group when they were stimulated with PMA. However, increase in IRE1 $\alpha$ was observed in the non-stimulated state only in the diabetic group. This same pattern was observed in CHOP gene expression. The content of peIF2 $\alpha$ was higher in the control group without stimulus and the other proteins of the PERK pathway showed no alteration. Gene expression of the MAM proteins was higher in the control group when neutrophils were stimulated with PMA. CHOP content was increased in the diabetic group. Finally, Caspase 3 activity and the reason $\mathrm{Bax} / \mathrm{Bcl} 2$ were higher in the diabetic group stimulated with PMA. In summary, our study found that neutrophils from diabetic rats when stimulated with PMA exhibit greater susceptibility to death due to activation of IRE1 $\alpha$ and subsequent phosphorylation of JNK, reduced safety in mitochondria-ER interaction in the MAM compartment and increased caspase- 3 activation. We also conclude that these changes were not altered by ROS, since the two groups, control and diabetic, have the same profile of these species production when stimulated with PMA. Control group seems to be protect against the ER stress by ROS production by higher expression of GRP78 and MAM proteins.

Keywords: Neutrophils. Endoplasmic reticulum stress. Diabetes mellitus. MAM. Caspase 3. 


\section{LISTA DE ILUSTRAÇÕES}

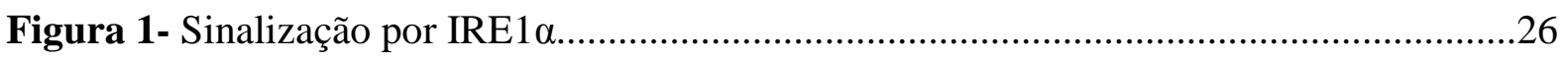

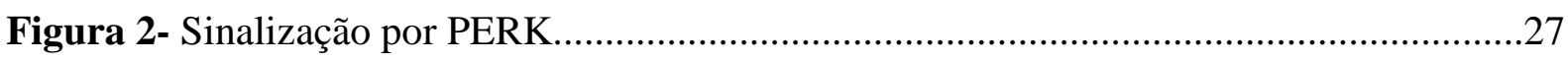

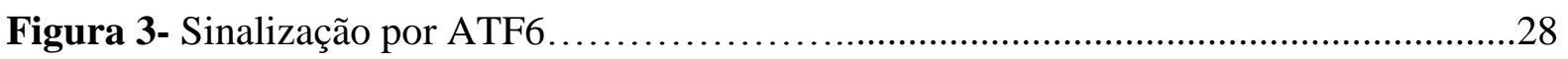

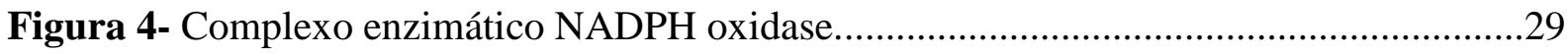

Figura 5- Proteínas que participam na regulação da MAM...................................................32

Figura 6- Ganho de peso (A), Glicemia (B) e Número de neutrófilos (C) dos grupos estudados

Figura 7- Fotomicrografia de neutrófilos para detecção do estresse de RE através de imunofluorescência. .45

Figura 8- Expressão gênica da chaperona GRP78 (BIP) por qPCR .......................................46

Figura 9- Expressão gênica dos componentes da UPR IRE1- $\alpha$ (A), PERK (B) e ATF6 (C) por

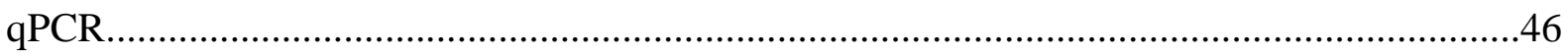

Figura 10- Expressão gênica do fator de transcrição CHOP por qPCR .................................47

Figura 11- Expressão gênica dos das proteínas reguladoras da MAM: Mitofusina-2 (A),

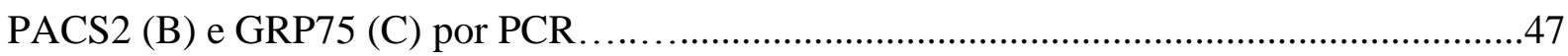

Figura 12- Expressão gênica da razão $\mathrm{Bax} / \mathrm{Bcl} 2$ por qPCR …..............................................48

Figura 13- Conteúdo das proteínas relacionadas à via da PERK da UPR..............................49

Figura 14- Splicing de XBP1(A) e fosforilação da proteína JNK (B), eventos decorrentes da

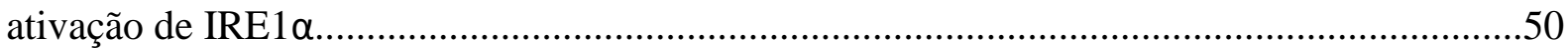

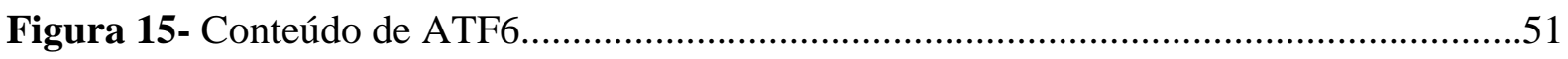

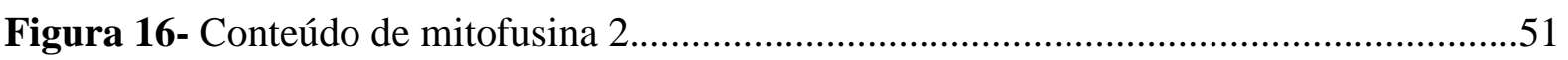

Figura 17- A produção de EROs por neutrófilos através de quimiluminescência e a ação dos

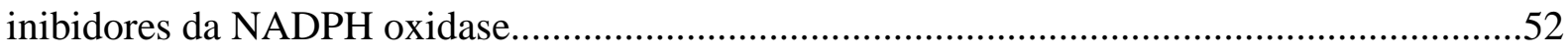

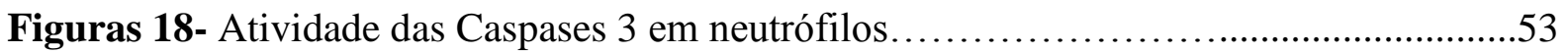




\section{LISTA DE ABREVIATURAS}

A1-Bcl-2-related protein A1

AIF - Apoptosis Inducing Factor

Apaf-1 - Apoptotic Protease Activating-Factor 1

APO-1 - apoptosis antigen 1

ASC-Apoptosis-associated speck-like protein containing a CARD

ASK1- Apoptosis signal-regulating kinase 1

ATF4- Activating Transcription Factor 4

ATF6- Activating Transcription Factor 6

ATG7- Autophagy related 7

ATP-Adenosine Triphosphate

Bad - Bcl-2-associated death promoter

Bak-Bcl-2 homologous antagonist/killer

Bax-Bcl-2-associated X protein

$\mathrm{Bcl}$ - B-cell lymphocytic-leukaemia proto-oncogene

BH - Bcl-2 Homology regions

Bid- BH3 interacting-domain death agonist

Bim- Pro-apoptotic BCL-2 family member

Blk- B lymphocyte kinase

Bmf- Bcl-2-modifying factor

Bnip3L- Bcl2/adenovirus E1B 19 kDa protein-interacting protein 3-like

Bok (Mtd)- Bcl-2 related ovarian killer

CARD- C-terminal caspase-recruitment domain

CD95 -cluster of differentiation 95

CHOP-CCAAT/enhancer-binding protein homologous protein

CINC2- Chemokine ( $C$-X-C motif) ligand 2

COX- Cyclooxygenase

CREB- cAMP responsive element binding protein

DNA- Deoxyribonucleic acid

EDEM- ER-degradation enhancer mannosidase alfa-like 1

EDTA - ácido etilenodiaminotetracético

eIF $2 \alpha$ - eukaryotic translation factor $2 \alpha$

EndoG - Endo-nuclease G 
ERAD- Endoplasmatic reticulum associated degradation

ERK- Extracellular signal-regulated kinases

EROs - espécies reativas de oxigênio

ERp44- Endoplasmatic reticulum protein $44 \mathrm{kDa}$

ERp57- Endoplasmatic reticulum protein $57 \mathrm{kDa}$

Fas- Apoptosis Stimulating Fragment (programmed cell death)

FasL - Fas ligante

GADD34- Growth arrest and DNA damage-inducible protein

GDP - Guanosine Diphosphate

GEF- Rho guanine nucleotide exchange factor (GEF)

GRP75- Glucose regulated protein $75 k D a$

GRP78- Glucose regulated protein $78 k D a$

GRP94- Glucose regulated protein $94 k D a$

GTP - Guanosine Triphosphate

HRK- Activator of apoptosis harakiri

HtrA2/Omi - High Temperatute Requirement A2/ stress-regulated endoprotease

ICAM - Intercellular Adhesion Molecule

IFN- $\gamma$ - interferon-gama

IgG - imunoglobulina $G$

$\mathrm{I}-\kappa \mathrm{B} \alpha$ - inhibitor of kappa light polypeptide gene enhancer in B-cells, kinase $\alpha$

IL- Interleukin

iNOS - inducible NOS

IP3R- inositol 1,4,5-trisphosphate receptor

IRE1- Inositol-requiring kinase 1

LPS - lipopolissacarídeo

Mcl-1- Induced myeloid leukemia cell differentiation protein Mcl-1

mRNA- messenger Ribonucleic acid

NAD+- Nicotinamida Adenina Dinucleotídeo

NADPH - Nicotinamida Adenina Dinucleotídeo Fosfato reduzida

Nbk/Bik- natural born killer/Bcl-2-interacting killer

NF- $\mathrm{B}$ - nuclear factor kappa-light-chain-enhancer of activated B cells

NOD- Nucleotide-binding oligomerization domain receptors

NOS- nitric oxide synthases

Noxa-Phorbol-12-myristate-13-acetate-induced protein 1 
PACS2- phosphofurin acidic cluster sorting protein 2

PAMPs- Pathogen-associated molecular patterns

PDI- Protein Dissulfide Isomerases

peIF2 $\alpha$-phosphorilated eIF $2 \alpha$ -

PERK-Double-stranded RNA-activated protein kinase-like ER kinase

PG - prostaglandina

PKC- Protein Kinase C

PMA - Phorbol 12-Myristate 13-Acetate

PMNs- Polimorfonucleares

PREX1- phosphatidylinositol-3,4,5-trisphosphate-dependent Rac exchange factor 1

Puma- p53 upregulated modulator of apoptosis

PYCARD- PYD and CARD domain containing protein

Rac2- ras-related C3 botulinum toxin substrate 2 (rho family, small GTP binding protein Rac2)

RAP1- member of RAS oncogene family

RE- Retículo Endoplasmático

RhoGDI- Rho GDP dissociation inhibitor (GDI) alpha

RNA- Ribonucleic acid

S1P- Site 1 protease

S2P- Site 2 Protease

SERCA- sarco/endoplasmic reticulum Ca2+-ATPase

Smac/ Diablo - Second Mitochondrial Derived Activator of Caspases/ Direct IAP Binding protein with Low $\mathrm{pI}$

SOD -Ssuperóxido dismutase

sXBP1- Spliced XBP1

TGF- $\beta 1$ - Transforming Growth Factor- $\beta 1$

TMB - 3,3',5,5'-tetramethylbenzidine

TNF - Tumor Necrosis Factor

TNFRs - Tumor Necrosis Factor Receptors

TRAF2- TNF receptor-associated factor 2

TRPP2- Transiente Receptor Potential Protein 2

XBP1- X-box binding protein 


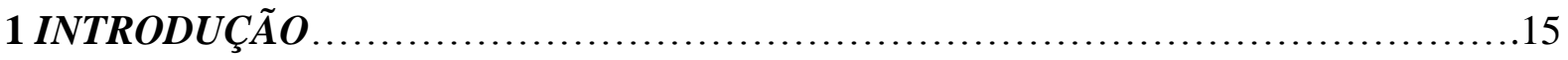

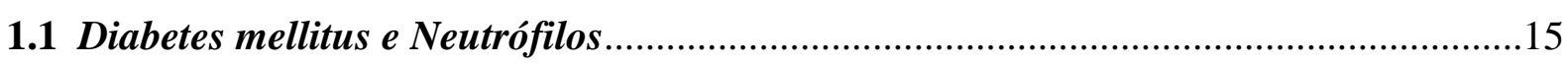

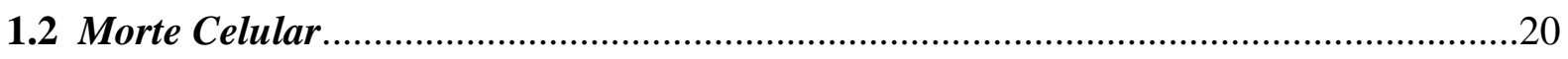

1.3 Estruturas que participam da morte celular em Neutrófilos........................................23

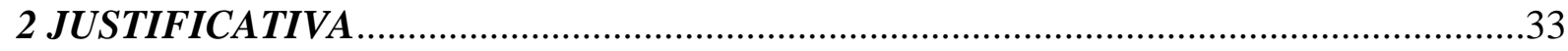

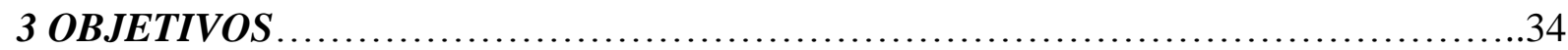

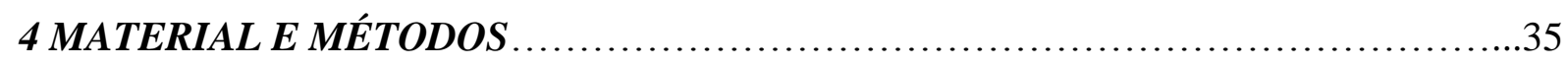

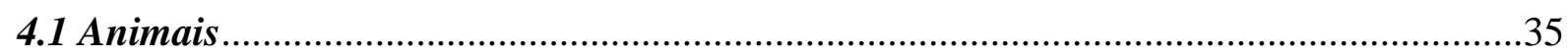

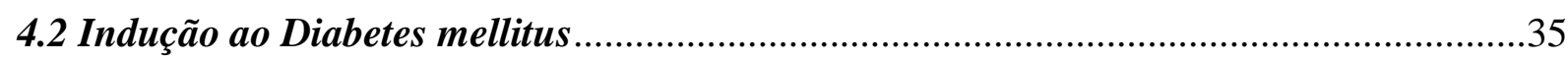

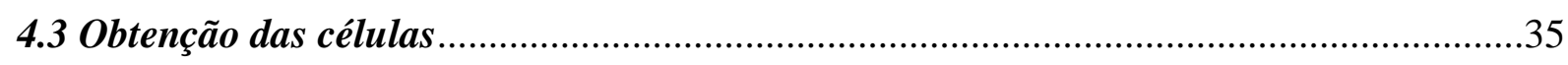

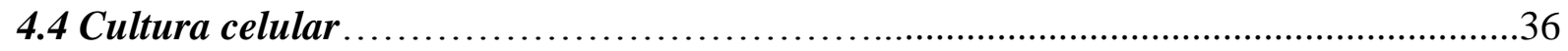

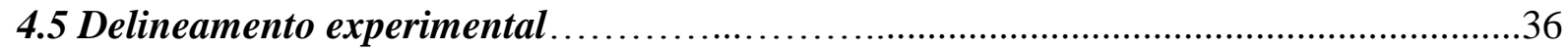

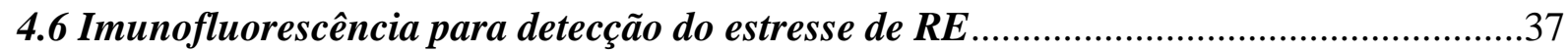

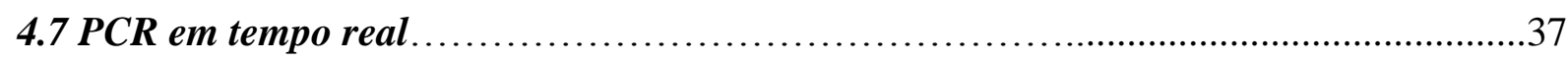

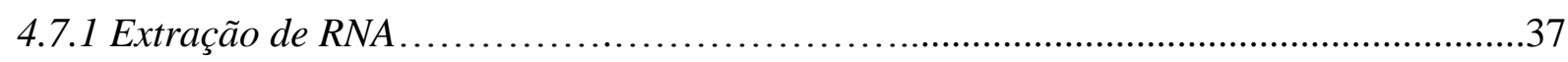

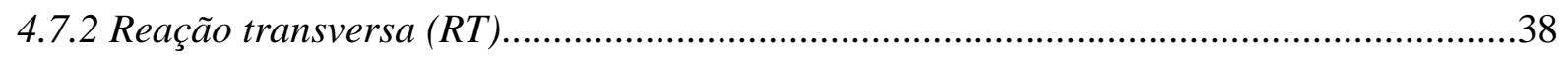

4.7.3 Real Time Polymerase Chain Reaction (Real time PCR)............................................38

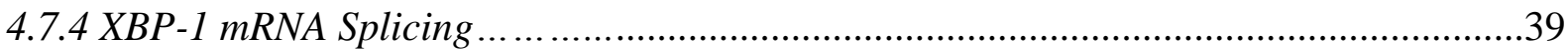

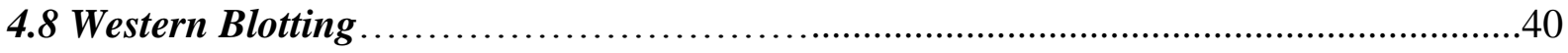

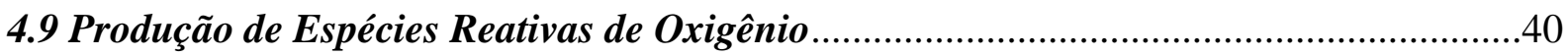

4.10 Atividade de caspase por espectrofluorescência .............................................................41

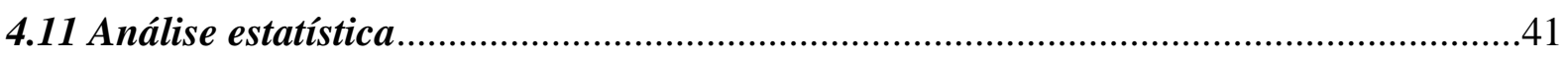

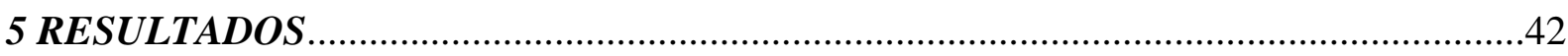

6 DISCUSSÃ

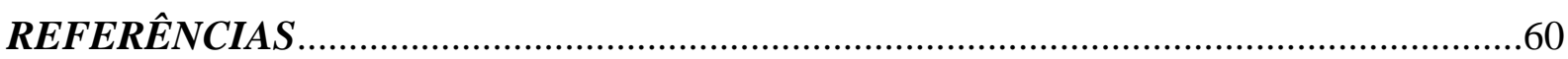

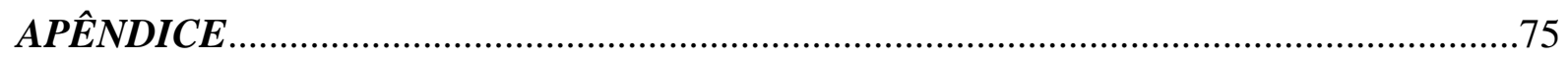

APÊENDICE A- Membranas coradas com ponceau para normalização das bandas...............75

APÊEDICE B-Trabalho submetido à PLoS ONE referente ao projeto BEPE......................76 


\section{INTRODUÇÃO}

\subsection{Neutrófilos e Diabetes mellitus}

Os leucócitos polimorfonucleares (PMNs) são as células brancas mais abundantes em humanos e corroboram na composição do sistema imune inato. Os neutrófilos são células fagocitárias que agem na primeira linha de defesa do organismo contra os microrganismos invasores e capazes de sintetizar citocinas, quimiocinas, fatores de crescimento e interferons (CASSATELA et al., 1999). Os neutrófilos possuem função importante na iniciação e sustentação do processo inflamatório, além de contribuir na regulação das reações imunes (SAVILL; HASLETT, 1995).

A resposta neutrofílica à lesão compreende a aderência destas células ao endotélio de vênulas pós-capilares (marginação leucocitária), a migração das células aderentes para o exterior do vaso, através de junções interendoteliais (diapedese), seu deslocamento no sítio extravascular (quimiotaxia) e subsequente acúmulo no sítio de lesão. Estes eventos dependem de duas propriedades fundamentais da célula: adesão e locomoção (TONNESEN, 1989).

Após a migração, os neutrófilos entram em contato com a partícula ou microrganismo invasor, o que promove a extensão do pseudópode e o englobamento da partícula, formando o fagossomo (MUDD et al., 1934). A capacidade de englobamento dos fagócitos é influenciada por moduladores (GILES et al., 2000) incluindo citocinas (FRANC; WHITE; EZEKOWITZ, 1999), prostaglandinas (REN; SAVILL, 1995), hormônios (ROSSI et al., 1998), endotoxinas (PAAPE et al., 2000) e metabólitos (VANHOLDER et al., 1993a, b). No entanto, a diminuição da capacidade fagocitária pode ser uma das causas para o aumento da predisposição à infecções em algumas patologias e condições de estresse (DJALDETTI et al., 2002).

As complexas vias de sinalização promovidas pelo englobamento de partículas ou microrganismos invasores levam a fusão de grânulos, ricos em proteases, com o fagossomo. A desgranulação no fagolisossomo ou no espaço extracelular são eventos-chave para a atividade microbicida (BERTON, 1999); mas, além das enzimas e proteínas liberadas pelos grânulos, a ação microbicida dos neutrófilos também depende da ativação da oxidase dependente de Nicotinamida Adenina Dinucleotídeo Fosfato reduzida (NADPH) (ROSSI; ZATTI, 1964) e, consequentemente, da geração de espécies reativas de oxigênio (EROs) que incluem o ânion superóxido $\left(\mathrm{O}_{2}^{--}\right)$, peróxido de hidrogênio $\left(\mathrm{H}_{2} \mathrm{O}_{2}\right)$, ácido hipocloroso $(\mathrm{HOCl})$ 
e radical hidroxil (OH) (BABIOR; KIPNES; CURNUTTE, 1973; FANTONE; WARD, 1982).

A resposta inflamatória aguda apresenta um "programa de parada" endógeno que visa limitar a destruição tecidual. A morte celular dos neutrófilos e a sua ingestão pelos macrófagos são os principais mecanismos para retirar os neutrófilos que recrutaram para o sítio de inflamação e, então, promover o término do processo inflamatório (SAVILL; HASLETT, 1995). Dessa maneira, alterações no processo de morte celular podem ser responsáveis pela permanência da resposta inflamatória causando prejuízo tecidual (PRINCE et al., 2011).

Alterações funcionais dos neutrófilos são encontradas em várias patologias, dentre elas a granulomatose de Wegener (WITKO-SARSAT; REUTER; MOUTHON, 2010), doença granulomatosa crônica (DINAUER et al., 1992), síndrome de Sweet (YI et al., 2009), artrite reumatoide (NÉMETH, 2012), lupus eritematoso (KAPLAN, 2011) e diabetes mellitus, entre outros.

O diabetes mellitus é caracterizado pela alta glicemia (hiperglicemia) devido a uma disfunção na secreção de insulina e/ou pela resistência periférica a este hormônio, acarretando alterações no metabolismo de carboidratos, lipídios e proteínas (COURTEN; HODGE; ZIMMET, 1998; WOLFF, 1993).

O diabetes mellitus pode ser, prevalentemente classificado em dois tipos: tipos 1 e 2 (ADA, 1997). O tipo 1 resulta da perda progressiva da capacidade das células $\beta$ pancreáticas em produzirem insulina, mediada por resposta auto-imune órgão-espécifica (ATKINSON; MACLAREN, 1994; KUKREJA; MACLAREN, 1999). O tipo 2 é caracterizada pela resistência periférica à insulina, perda na capacidade de regulação da produção de glicose hepática e declínio da função da célula $\beta$, eventualmente ocasionando a falência celular (OLEFSKY, 1989).

No diabetes mellitus há varias complicações metabólicas, como elevada produção hepática de glicose por glicogenólise e gliconeogênese, diminuição da utilização de glicose pelo músculo esquelético e tecido adiposo, aumento da lipólise e oxidação de ácidos graxos (BONADONNA; DE FRONZO, 1991). Além dessas complicações, existem também as alterações micro e macro-vasculares que acarretam uma redução da resposta inflamatória (GEERLINGS et al., 1999).

Estudos dos leucócitos na vigência do diabetes mellitus vêm sendo desenvolvidos, desde a década de 70 nos quais são verificadas alterações funcionais e metabólicas 
importantes em neutrófilos de pacientes diabéticos tipo 1. Em 1971, Mowat e Baum observaram diminuição do movimento quimiotáxico de neutrófilos em pacientes com diabetes mellitus. Tan et al., em 1975, correlacionaram o aumento da susceptibilidade de pacientes diabéticos à infecção com a capacidade bactericida ineficiente dos neutrófilos. Em 1978, Nolan et al. verificaram diminuição da fagocitose por granulócitos em pacientes com diabetes não controlado.

Os estudos continuaram na década de 80 , nos quais se verificou que o burst oxidativo estava diminuído no neutrófilo de pacientes com diabetes mellitus (MARKERT et al., 1984; SAGONE et al., 1983; WILSON, 1986); e que a glicose e os corpos cetônicos influenciam esta função neutrofílica através da via dos polióis (WILSON; REEVES, 1986). Nesta via atuam duas enzimas importantes: a primeira, aldose redutase, reduz glicose a sorbitol e utiliza o NADPH como co-fator, e a segunda, sorbitol desidrogenase, utiliza nicotinamida adenina dinucleotídeo (NAD+) como co-fator e converte sorbitol em frutose. Como clinicamente se observava diminuição da resistência à infecção no diabetes, características gerais destas células, como fagocitose, capacidade bactericida e produção de ânion superóxido foram investigadas (NIELSEN; HINDSON, 1989; REPINE et al., 1980; WIERUSZ-WYSOCKA et al., 1985). Em alguns casos, o estudo foi restrito a infecções mais comuns nestes pacientes, como àquelas causadas por Staphylococcus aureus e Escherichia coli (MARKERT et al., 1984; RAYFIELD et al., 1982). No final da década de 80 e início da de 90, demonstrou-se ocorrer diminuição da adesão dos neutrófilos ao endotélio e, consequentemente, da migração neutrofílica, o que estaria envolvida na baixa resistência à infecção no diabetes (ANDERSEN; GOLDSMITH; SPAGNUOLO, 1988; FORTES et al., 1991; PEREIRA et al., 1987; SANNOMIYA et al., 1990).

A inibição da quimiotaxia de leucócitos, associada ao estado diabético, é um evento de instalação precoce. A migração de neutrófilos para o foco da lesão encontra-se diminuída, em modelo de pleurisia, 3 dias após a indução do diabetes mellitus, coincidindo com o aparecimento de uma proteína de $(12 \mathrm{kDa})$, no plasma, com efeito inibitório sobre a quimiotaxia. O tratamento relativamente prolongado (12 dias) dos animais com insulina resulta na recuperação gradual da quimiotaxia avaliada in vivo, em modelo de pleurisia por análise em microscopia intravital, e in vitro por análise em câmara de Boyden. Tratamentos agudos (3 dias) são inefetivos (PEREIRA et al., 1987; SANNOMIYA et al., 1990).

Utilizando-se da técnica de microscopia intravital, Fortes et al. (1991) verificaram que o número de leucócitos em contato com o endotélio vascular (rolling behavior) encontra-se marcadamente reduzido em ratos diabéticos. Entretanto, o número de leucócitos circulantes 
não está alterado. Sob influência de um estímulo inflamatório, leucócitos migram para o tecido perivascular de animais controles e este evento acompanha-se de redução no número de células que rolam sob o endotélio (rollers). Nos animais diabéticos, o número de leucócitos em rolling behavior não se altera e esse pequeno número de células migra para o tecido conectivo adjacente. A interação alterada leucócito-endotélio não é observada em animais diabéticos tratados com insulina (FORTES et al., 1991). As alterações da interação leucócitoendotélio no diabetes mellitus associam-se à presença da proteína (>12kDa), que por sofrer reação de glicação (SANNOMIYA et al., 1997), apresenta atividade inibitória sobre a expressão da molécula de adesão denominada Intercellular Adhesion Molecule-1 (ICAM-1) em células endoteliais de vênulas pós-capilares (ANJOS-VALLOTA et al., 1999).

A capacidade de resposta leucocitária a gradientes de concentração de estímulos quimiotáxicos é essencial para a defesa do hospedeiro contra microrganismos invasores (WARD, 1974). Alterações na quimiotaxia, quando presentes, tornam o paciente diabético mais susceptível à infecções. A diminuição da quimiotaxia nesses pacientes (DELAMAIRE et al., 1997; GEERLINGS; HOEPELMAN, 1999), pode ser consequência da hiperglicemia (WIERUSZ-WYSOCKA et al., 1988), embora Tater et al. (1987) não tenham demonstrado correlação entre quimiotaxia e valores glicêmicos.

Neutrófilos de pacientes com diabetes mellitus tipo 1 apresentam diminuição da capacidade fagocítica (DELAMAIRE et al., 1997; MARHOFFER et al., 1992; WALRAND et al., 2004). Contudo, Tater et al. (1987) e Balasoiu et al. (1997) não encontraram a mesma alteração. A atividade bactericida exercida pelos neutrófilos apresenta-se diminuída em pacientes diabéticos (GALLACHER et al., 1995; WALRAND et al., 2004). Por sua vez, vários pesquisadores (GALLACHER et al., 1995; NIELSON; HINDSON, 1989; OLDENBORG et al., 2000; ORTMEYER; MOHSENIN, 1996; PERNER et al., 2003), exceto Mohanty et al. (2000) observaram que a hiperglicemia diminui a capacidade de burst respiratório de neutrófilos.

A produção de citocinas por neutrófilos também é alterada pela hiperglicemia e/ou hiperinsulinemia. Pacientes diabéticos apresentam valores basais séricos elevados de Tumor Necrosis Factor- $\alpha$ (TNF- $\alpha$ ), Interleukin (IL)-6 e IL-8 (MYSLIWSKA et al., 1998; PICKUP; CROOK, 1998; ZOZULINSKA et al., 1976). Entretanto, os efeitos da glicose e insulina na produção de citocinas pró-inflamatórias induzida por lipopolisacarídeo (LPS) in vitro e in vivo são contraditórias (FRAKER; MERINO; NORTON, 1989; KIRWAN et al., 2001; LIDA et al., 2001; ORLINSKA; NEWTON, 1993; SATOMI et al., 1985). Em modelo de inflamação pulmonar aguda induzida por LPS, animais diabéticos apresentam redução (50\%) na geração 
de íons superóxido por neutrófilos presentes no lavado broncoalveolar e a mesma magnitude de redução da concentração de TNF- $\alpha$ no sobrenadante deste (BOICHOT et al., 1999). A produção/liberação de prostaglandina E2 $\left(\mathrm{PGE}_{2}\right)$ por estas células também está reduzida (ALBA-LOUREIRO et al., 2006a). Martins et al. (2006) verificaram que a insulina modula a produção/liberação de citocinas pró inflamatórias (TNF- $\alpha$ e IL-1 $\beta$ ) e anti inflamatória (IL-10) no lavado broncoalveolar, a expressão de moléculas de adesão Intercellular Adhesion Molecule-1 (ICAM-1) e E-selectina no endotélio pulmonar e a migração de neutrófilos para o mesmo órgão após instilação intratraqueal de LPS. Essa modulação pelo hormônio pode ser atribuída, em parte, pela ativação da subunidade p65 da nuclear factor kappa-light-chainenhancer of activated B cells (NF- $\mathrm{KB})$ e fosforilação de inhibitor of kappa light polypeptide

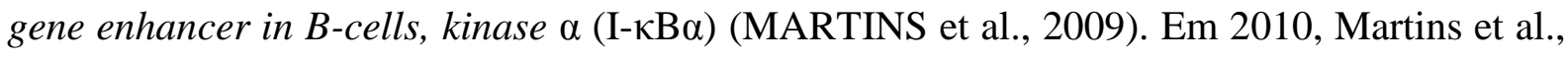
verificaram que ratos diabéticos tratados com LPS exibiram redução na fosforilação das proteínas Extracellular signal-regulated kinases (ERK), p38, Akt, Protein Kinase C- $\alpha$ (PKC$\alpha)$ e Protein Kincse C- $\gamma(\mathrm{PKC}-\gamma)$ e, redução na expressão do inducible nitric oxide synthase (iNOS) e Cyclooxygenase 2 (COX-2) no exsudato proteico proveniente do tecido pulmonar, redução na concentração de nitric oxide synthase (NO) e IL-6 e aumento dos níveis de Chemokine (C-X-C motif) ligand 2 (CINC-2) no lavado broncoalveolar. O tratamento dos animais diabéticos com insulina promoveu o retorno da fosforilação das moléculas de sinalização, expressão de enzimas e dos níveis da produção/liberação das citocinas aos apresentados pelos animais controles.

Alba-Loureiro et al. (2006b) verificaram redução na utilização de glicose e glutamina para produção de Adenosine Triphosphate (ATP) e aumento da oxidação de ácido palmítico por neutrófilos de ratos diabéticos. Estas alterações metabólicas devem estar relacionadas com a diminuição da produção de peróxido de hidrogênio e da capacidade fagocitária destas células.

Como descrito acima, várias alterações funcionais e metabólicas foram descritas em neutrófilos no diabetes tipo 1. Porém, a morte dos neutrófilos induzida por estímulos inflamatórios na condição diabética ainda não é bem esclarecida. Dessa forma, o entendimento por quais vias e de que maneira essas células estão morrendo é essencial para uma boa abordagem terapêutica posterior. 


\subsection{Morte Celular}

Inicialmente, acreditava-se que o processo de morte celular ocorria basicamente através da apoptose ou necrose. No entanto, com a evolução da ciência e a aparição de métodos analíticos mais sensíveis, outros mecanismos de morte celular têm sido caracterizados e são influenciados por fatores intracelulares (ATP, variação da concentração de íons cálcio no citoplasma) e extracelulares (pH, marcadores de inflamação) que as células estão expostas.

Atualmente, existe um grande consenso de que os vários tipos de morte celular não estão separados por fronteiras bem estabelecidas, mas sim compartilham de alguns dos mecanismos moleculares e rotas de sinalização (LEVIN et al., 2008). A morte celular é extremamente importante para a embriogênese, desenvolvimento de tecidos e para homeostasia de organismos pluricelulares (KERR et al., 1972). Uma deficiência no processo de morte pode ser deletéria e está relacionada a um conjunto de condições patológicas como doenças autoimunes, doenças neurodegenerativas, câncer, AIDS, entre outros (HETTS, 1998; PERRY et al., 1998; THOMPSON, 1995). As células em geral contam com uma maquinaria muito eficiente e controlada para desencadear sua morte, e esta é desencadeada se a célula não está desempenhando mais sua função ou já cumpriu o seu papel determinado.

A apoptose é um processo de morte celular controlado, em que a célula é programada para morrer através da ativação de várias proteínas responsáveis por esse processo. Esse processo de morte celular não inflamatório é caracterizado pela formação de protuberâncias na superfície celular (blebs), condensação do núcleo e citoplasma. Uma das primeiras alterações marcantes no processo apoptótico é a agregação e condensação da cromatina em grandes massas granulares compactas que se ligam à carioteca formando um núcleo picnótico. Em estágio posterior, ocorre a clivagem do DNA internucleossomal com o aparecimento de fragmentos nucleares discretos (KERR et al. 1972). Enquanto isso, o citoplasma se condensa, aumenta a densidade de organelas intactas e microvilos desaparecem, levando a diminuição do volume celular e a desintegração de junções celulares. Além da diminuição de volume celular, a externalização de fosfatidilserina é uma marca do início do processo de apoptose. Em células vivas, os fosfolípides da membrana plasmática, fosfatidilcolina e esfingomielina, estão localizados na face externa; enquanto, a fosfatidilserina, exclusivamente, na face interna da membrana plasmática. Na apoptose ocorre a perda da simetria dos fosfolípides devido a exposição de fosfatidilserina para a face externa da membrana plasmática, acarretando na translocação de cargas negativas da molécula de fosfolipídios da face interna da membrana 
citoplasmática para a superfície célular (MARTIN et al., 1996). Este processo facilita o reconhecimento das células apoptóticas por células fagocíticas que apresentam receptores para fosfatidilserina (VERMES et al., 1995).

A apoptose de neutrófilos também envolve cascatas proteolíticas com caspases, calpainas e proteassoma que ativam quinases, dissociam a ligação protéica dos filamentos de actina (KNEPPER-NICOLAI; SAVILL; BROWN, 1998), e participam nas transformações morfológicas nucleares (WITKO-SARSAT et al., 2000). Existem duas principais vias que regulam a apoptose, a primeira é a via dos receptores de morte ou extrínseca, iniciada pelos Tumor Necrosis Factor Receptors (TNFRs) e pelos Apoptosis Stimulating Fragments (Fas), cluster of differentiation 95/ apoptosis antigen 1 (CD95/Apo-1) e, a segunda, a via intrínsica, que envolve mitocôndria e membros da família $\mathrm{Bcl} 2$ (B-cell lymphocytic-leukaemia protooncogene-2) (ASHKENAZI; DIXIT, 1998; GREEN, 1998; TSUJIMOTO; SHIMIZU, 2000).

As proteínas da família Bcl2 localizam-se no citoplasma e membrana mitocondrial externa e entram na regulação e integração de sinais de morte ou de sobrevivência celular. Bcl2 se divide em três subfamílias: duas delas que possuem multidomínios Bcl-2 Homology regions $(\mathrm{BH})$, que são anti-apoptóticas Bcl-2, B-cell lymphocytic-leukaemia proto-oncogene extra large (Bcl- $\left.\mathrm{X}_{\mathrm{L}}\right)$, B-cell lymphocytic-leukaemia proto-oncogene-w (Bcl-w), Induced myeloid leukemia cell differentiation protein (Mcl-1) e Bcl2-related protein A1 (A1/Bfl-1); ou próapoptóticas Bcl-2-associated X protein (Bax), Bcl-2 homologous antagonist/killer (Bak), Bcl2 related ovarian killer (Bok/Mtd) e B-cell lymphocytic-leukaemia proto-oncogene -rambo (Bcl-rambo) e atuam na integridade das membranas mitocondriais. A outra subfamília compreende as proteínas pró-apoptóticas que possuem somente o domínio BH3, denominadas de BH3-only proteins Bcl-2-associated death promoter (Bad), natural born killer/Bcl-2interacting killer (Nbk/Bik), BH3 interacting-domain death agonist (Bid), Pro-apoptotic Bcl2 family member (Bim/Bod), Activator of apoptosis hara-kiri (Hrk/DP5), Phorbol-12myristate-13-acetate-induced protein 1 (Noxa), B lymphocyte kinase (Blk), Bcl2/adenovirus E1B 19 kDa protein-interacting protein 3-like (Bnip3L/Nix), p53 upregulated modulator of apoptosis (Puma), Bcl-2-modifying factor (Bmf) e B-cell lymphocytic-leukaemia protooncogene-G (Bcl-G). As "BH3-only" são ligantes que ativam proteínas das pró-apoptóticas ou inativam as anti-apoptóticas. Alterações na expressão, localização subcelular, estado de fosforilação e processamento proteolítico das proteínas Bcl-2 determinam se o programa de morte será ativado (BORNER, 2003; KORSMEYER, 1995; MAYER; OBERBAUER, 2003). 
Os neutrófilos expressam constitutivamente membros pró-apoptóticos da família Bcl2, incluindo Bax, Bak, Bad, Bid e Bik e, a Mcl-1, membro anti-apoptótico (AKGUL et al., 2001; EDWARDS et al., 2004; MOULDING et al., 2001). No processo de apoptose destas células, a mitocôndria muda de forma, formando clusters perinucleares (MAIANSKI et al., 2004) nos quais as proteínas pró-apoptóticas se fundem, promovem a permeabilização e, consequentemtente, a liberação de proteínas mitocondriais pró-apoptóticas (NEWMEYER; FERGUSON-MILLER, 2003). O citocromo c, fator mitocondrial pró-apoptótico, associado ao Apoptotic Protease Activating-Factor 1 (Apaf-1), ATP e a pró-caspase 9 formam o apoptossomo (GREEN, 1998). A caspase 9 é ativada no apoptossomo e, subsequentemente, ativa a caspase 3 (BOATRIGHT; SALVESEN, 2003; LI et al., 1997). Apesar das poucas mitocôndrias de neutrófilos expressarem baixas quantidades de citocromo c (LIU et al., 2003; MURPHY et al., 2003; PRYDE et al., 2000), este seria suficiente para induzir a ativação da caspase 9 (MURPHY et al., 2003), indicando que embora a atuação destas organelas seja discreta na respiração, elas preservam a ativação de caspase na apoptose (MAINSKI et al., 2004).

Outro mecanismo de morte programada que vem ganhando evidência é a autofagia. Neste tipo de morte, as células catabolizam componentes celulares danificados para que os elementos essenciais - carboidratos, proteínas e lipídios - possam ser reutilizados para reparos celulares. A morte celular induzida por autofagia é desencadeada quando a célula está em condições de inanição ou quando há estresse no reticulo endoplasmático. Apesar desse mecanismo não ser totalmente conhecido, há necessidade da expressão de genes como o beclin 1 e autophagy related 7 (ATG7) para que ocorra (LIANG et al., 1999; YU et al., 2004). Nesse processo não há ativação de caspases, mas há condesamento citoplasmático e uma redução do tamanho celular (KLIONSKY et al., 2008). A característica única da autofagia é a formação de autofagossomos multilamelares que englobam componentes intracelulares, facilmente detectados por microscopia eletrônica, que são degradados durante a fusão com o lisossomo (SAFTIG et al., 2008).

A piroptose é também um processo de morte programado. Porém, resulta em lise da célula, inflamação do tecido e recrutamento de fagócitos profissionais. A enzima chave no processo é a caspase-1 que ativa as citocinas IL-1 $\beta$ e IL-18, responsáveis por recrutar macrófagos e polimorfonucleares para o sitio de infecção (FINK; COOKSON, 2006). A caspase-1 também está relacionada com a formação de poros na membrana celular, permitindo um influxo de íons extracelulares que promovem o aumento do tamanho e lise celular. Semelhante ao apoptossomo que medeia a apoptose, a piroptose é controlado pela 
formação de uma multiproteína $(700 \mathrm{kDa})$ conhecida como inflamasomo. Esse complexo é composto por um sensor denominado de Nucleotide-binding oligomerization domain receptor (NOD)-like receptor (KANNEGANTI; LAMKAN; NUNEZ, 2007), uma molécula adaptadora contendo C-terminal caspase-recruitment domain (CARD), Apoptosis-associated speck-like protein containing a CARD (ASC) ou PYD and CARD domain containing protein (PYCARD), caspase-1 e caspase-5 (FERNANDES-ALNEMRI et al., 2007). A interação das moléculas do sensor com ligantes como os Pathogen-associated molecular patterns (PAMPs) desencadeia a formação dos inflamassomos (FINK; COOKSON, 2006).

Como a piroptose, a oncose é caracterizada pelo aumento do tamanho e lise celular devido principalmente pela formação de poros por toxinas de bactérias patogênicas e lise mediada pelo sistema complemento (LEVIN et al., 1999). A oncose ocorre quando há perda de integridade da membrana, liberação do conteúdo intracelular e o efluxo de íons inorgânicos, promovendo o aumento da pressão osmótica intracelular e dentro das organelas. A depleção de ATP e perda de potencial transmembrânico de mitocôndrias acompanham o efluxo de íons da célula (TRUMP; BEREZESKY, 1996; PEREZ et al., 1998).

Neutrophil Extracelular Traps (NET)ose é um tipo de morte celular exclusivo de neutrófilos, caracterizada pela formação de redes extracelulares compostas por extrusões de membrana plasmática, material nuclear, componentes de grânulos e histonas. A formação dessas "redes" tem como objetivo aprisionar os agentes invasores ao mesmo tempo que exerce sua função microbicida, (FUCHS et al., 2007), sendo necessária da ativação da NADPH oxidase (produção de EROs) (DACHEUX et al., 2000).

\subsection{Estruturas que participam no processo de morte celular em Neutrófilos}

A mitocôndria tem sido caracterizada como a organela chave no processo de morte dos neutrófilos (MAIANSKI et al., 2004; RAAM et al., 2006). Tais fagócitos possuem poucas mitocôndrias, sugerindo que não sejam essenciais para o fornecimento de energia, mas sim fundamentais no processo de morte dos neutrófilos. As mitocôndrias desempenham tal papel, não apenas por possuírem proteínas citotóxicas que são liberadas durante o processo de apoptose, Second Mitochondrial Derived Activator of Caspases/ Direct IAP Binding (Smac/DIABLO), High Temperatute Requirement A2/ stress-regulated endoprotease (HtrA2/Omi), Endonuclease G (Endo G), Apoptosis inducing factor (AIF), Citocromo C, e contribuírem para a ativação de caspases, mas também por agirem como sensores de cálcio metabólico, evidenciando o estado redox da célula e como aceptores de cálcio livre do 
citoplasma. O balanço da expressão e atividade de compostos pró e anti-apoptóticos da família de proteínas Bcl-2 determinaria o tempo de vida dos neutrófilos (RAAM et al., 2006).

O retículo endoplasmático (RE) é outra organela que vem ganhando evidência quando se trata de morte celular. Todas as proteínas que transitam pela via de secreção nas células eucarióticas entram primeiramente no RE, sofrem alterações conformacionais, formam complexos e são exportadas em vesículas para o Complexo de Golgi para posteriormente serem secretadas. No decorrer do processo de formação e saída de compostos do RE, há um processo de controle de qualidade que impede a má formação de proteínas e a secreção das mesmas (MALHOTRA; KAUFMAN, 2007; VOELTZ et al., 2002). As proteínas mal formadas são retidas no lúmen do RE em complexos com chaperonas ou são enviadas diretamente para a degradação pelo $26 \mathrm{~S}$ proteossomo, através do processo chamado de $E R$ associated degradation (ERAD).

O RE possui um microambiente único que favorece a formação conformacional das proteínas desde o início quando as cadeias de polipeptídios nascentes adentram seu lúmen. Este é um meio altamente oxidante para favorecer a formação de pontes dissulfeto que são necessárias para gerar a conformação correta das proteínas. Para garantir que a formação dessas pontes dissulfeto seja feita de forma correta, a célula apresenta as oxidoredutases Protein Dissulfide Isomerases (PDIs) e 57kDa Endoplasmatic reticulum Resident protein (ERp57), que catalisam tais reações (LAURINDO; PESCATORE; FERNANDES, 2012; OLIVER et al., 1997; WILLIAM, 2006). A alta concentração de proteínas parcialmente formadas e daquelas que ainda não sofreram alterações conformacionais aumentam a probabilidade de formação de agregados que podem gerar o estresse do RE. Dessa maneira, o RE apresenta proteínas como a 78kDa Glucose-regulated Protein (GRP78, conhecida também como Bip) e a 94kDa Glucose-regulated Protein (GRP94), que se ligam a tais proteínas mal formadas impedindo a aglomeração entre elas (MALHOTRA; KAUFMAN, 2007).

O RE é também o depósito primário de cálcio da célula. Tanto a formação de novas proteínas como a função exercida pelas chaperonas exigem altos níveis de cálcio intraluminal. A formação de proteínas no RE necessita de grande quantidade de energia, o ATP também é necessário para manter as funções das chaperonas, os níveis de íons cálcio intraluminal, o estado redox e o ERAD do RE (MALHOTRA; KAUFMAN, 2007; MA; HENDERSHOT, 2001).

O acúmulo de proteínas mal formadas inicia a ativação de uma cascata de sinalização conhecida como Unfolded protein response (UPR). Atualmente, é bem estabelecido que a resposta ao estresse de RE ocorre devido a ativação de três componentes constitutivos 
transmembrânicos de reticulo: Inositol-requiring kinase 1 (IRE1), Double-stranded RNAactivated protein kinase-like ER kinase (PERK) e Activating transcription factor 6 (ATF6) (BERNALES; PAPA; WALTER, 2006; SHRODER et al., 2005).

O IRE1 é uma proteína transmembrânica de 110kDa que possui dois homólogos: IRE1 $\alpha$ e IRE1 $\beta$. O IRE1 $\alpha$ é expresso em quase todas as células e tecidos, com altos níveis de expressão no pâncreas e placenta. IRE1 $\beta$ é expresso apenas nas células do epitélio intestinal. Ambos possuem funções parecidas, diferenciando apenas em suas localizações (TIRASOPHON et al., 1998; WANG et al., 1998). Em seu estado inativo, o domínio luminal do IRE1 está associado a chaperona do RE, Bip. Quando a concentração de proteínas mal formadas aumenta no lúmen do RE, Bip dissocia-se do IRE1 para se ligar as proteínas mal formadas e impedir a aglomeração das mesmas. Essa dissociação faz com que o IRE1 oligomerize com outras moléculas de IRE1, também dissociadas, acarretando a autofosforilacao do seu domínio citoplasmático e a consecutiva ativação da IRE1 ribonuclease (RNAse) (TODD et al., 2008). Essa RNAse cliva o X-box binding protein (XBP1) mRNA para retirada de um intron de 26 nucleotídeos, resultando no spliced XBP1 (XBP1s) que é um ativador da transcrição de vários genes relacionados a UPR. Alguns dos genes que são ativados pela via IRE1/XBP1 são os envolvidos no ERAD, como o ER-degradation enhancer mannosidase alfa-like 1 (EDEM) (Figura 1) (YOSHIDA et al., 2003). Além do processamento do XBP1 mRNA, IRE1 promove, direta ou indiretamente, a rápida quebra e destruição de vários mRNAs associados com o RE rugoso, promovendo a diminuição da entrada de novas proteínas no lúmen dessa organela. A forma ativada do IRE1 se liga ao Tumor Necrosis Factor receptor-associated factor 2 (TRAF2), ativando a quinase próapoptótica JUN N-terminal kinase (JNK), através da proteína Apoptosis signal-regulating kinase 1(ASK1) (URANO et al., 2000). JNK ativada pode, então, ativar a morte celular por apoptose ou autofagia. A atividade de IRE1 é modulada pela interação com BAX inhibitor 1 e de proteínas da família Bcl-2 (HETZ; GLIMCHER 2008; LISBONA et al., 2009). 
Figura 1- Sinalização por IRE-1.

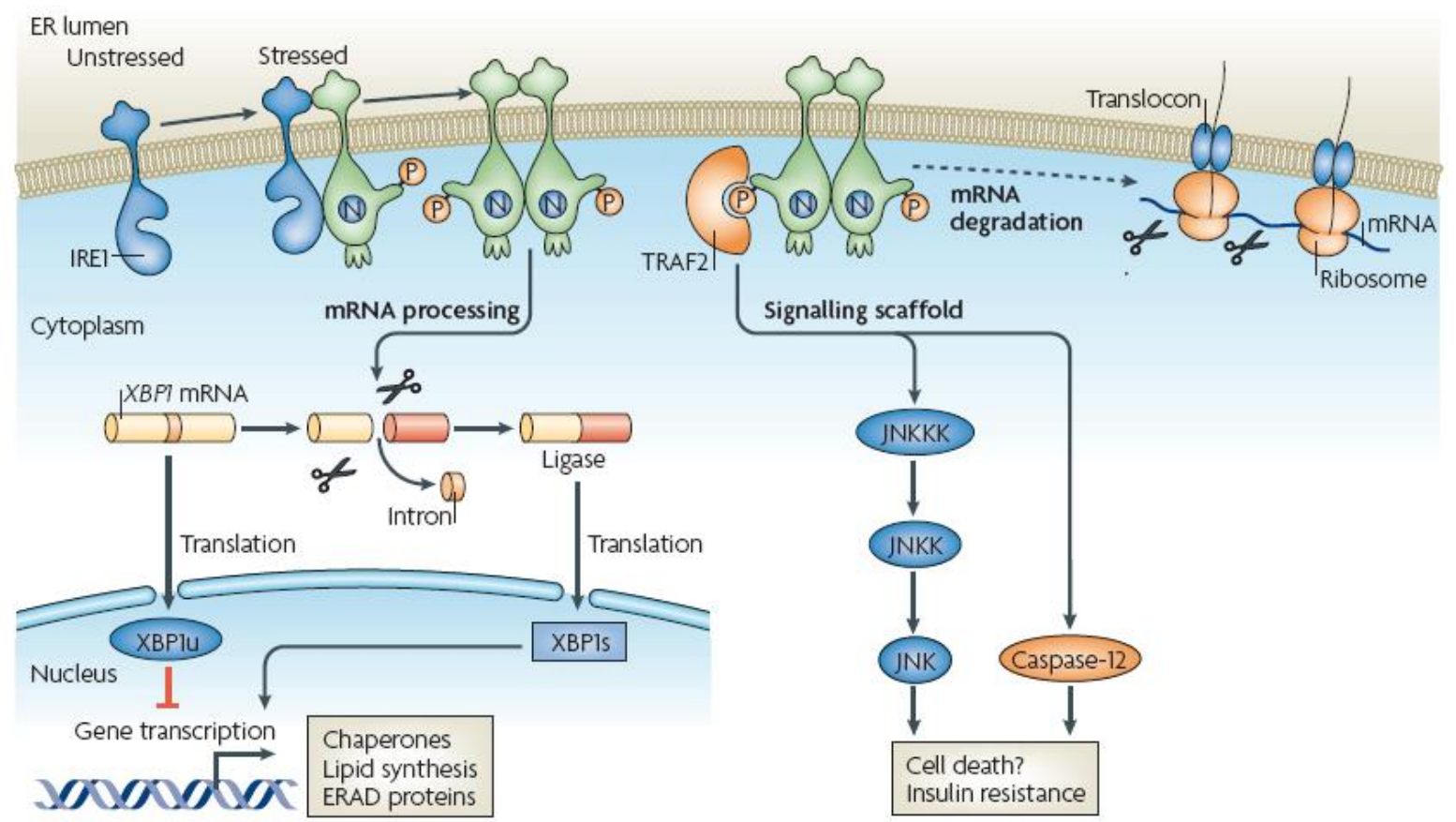

Em situações de estresse no reticulo endoplasmático, IRE-1 se dimeriza, autofosforila no seu domínio quinase citosólico e atua como endoribonuclease.

Fonte: (RON; WALTER, 2007)

O PERK é também uma proteína transmembranica, de 120kDa, cujo o domínio luminal é semelhante ao de IRE1 e se liga a Bip. Quando a concentração de proteínas mal formadas aumenta no lúmen do RE, PERK se dissocia da Bip, dimeriza-se e autofosforila, levando a ativação do eukaryotic translation factor $2 \alpha$ (eIF2 $\alpha$ ) através da fosforilação em Serina na posição 51 (Ser51) (HARDING et al., 2000; HARDING et al., 2000b). Embora a fosforilação do eIF2 $\alpha$ - necessária para o acoplamento da subunidade $80 \mathrm{~S}$ do ribossomo (LU et al., 2004) - iniba a síntese geral de proteínas, ela é necessário para a tradução de vários mRNAs. Um fator de transcrição cuja tradução é ativada pela fosforilação do eIF2 $\alpha$ é o Activating Transcription Factor 4 (ATF4) (HARDING; ZHANG; RON, 1999), que pertence a família do cAMP-response element binding (CREB) e ativa vários genes envolvidos no controle da UPR, incluindo chaperonas (Bip e a GRP94); genes envolvidos na supressão do estresse oxidativo, no metabolismo e transporte de aminoácidos (Figura 2). ATF4 também atua na ativação da CCAAT/enhancer-binding protein homologous protein (CHOP), que embora ocorra no início da ativação da UPR, está correlacionado com apoptose após prolongado estresse de RE em alguns tipos celulares e em vários estados patológicos (ZINSZNER et al., 1998). 
Figura 2- Sinalização por PERK.

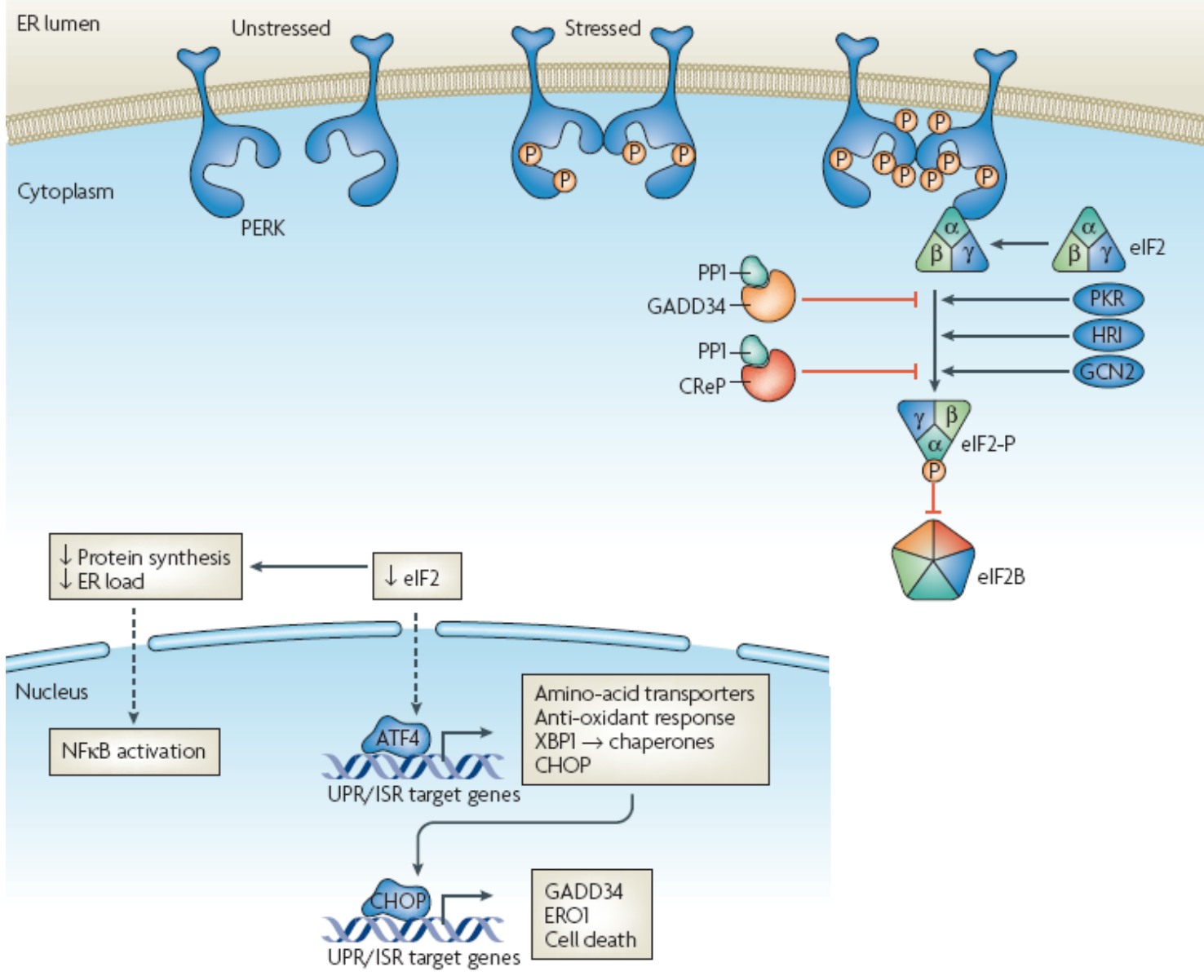

Em resposta ao estresse de RE, PERK dimeriza, se autofosforila, promovendo assim sua ativação. A fosforilação da subunidade $\alpha$ do eIF2 na Ser51, inibe o eIF2B de reciclar o eIF2 em sua forma ativa ligada a GTP. O resultado reduz atividade do eIF2B e o complexo eIF2 passa a exercer todas as funções importantes mediada por PERK.

Fonte: (RON; WALTER, 2007)

ATF6 é uma proteína transmembrânica de 90kDa, que permanece no RE durante condições normais através de sua associação com Bip (STEN et al., 2002). Quando a concentração de proteínas mal formadas aumenta no lúmen do RE e Bip se dissocia, ATF6 é translocado para o Complexo de Golgi, onde é clivado por proteases site-1 (S1P) e site-2 (S2P), que liberam o domínio citosólico de 50-kDa como um fator de transcrição ativo $\left(\mathrm{ATF}_{50}\right)$. O ATF6 50 se desloca até o núcleo e ativa a transcrição de vários genes envolvidos no controle de qualidade do RE, incluindo chaperonas como a Bip, XBP1, componentes do ERAD, o indutor de apoptose CHOP e o Ero1 $\beta$ (Endoplasmatic reticulum resident oxiredutase 1 $1 \beta$ ) que tem um papel essencial na manutenção do ambiente oxidante do RE (SHIMIZU; HENDERSHOT, 2009) (Figura 3). 
Figura 3- Sinalização por ATF6.

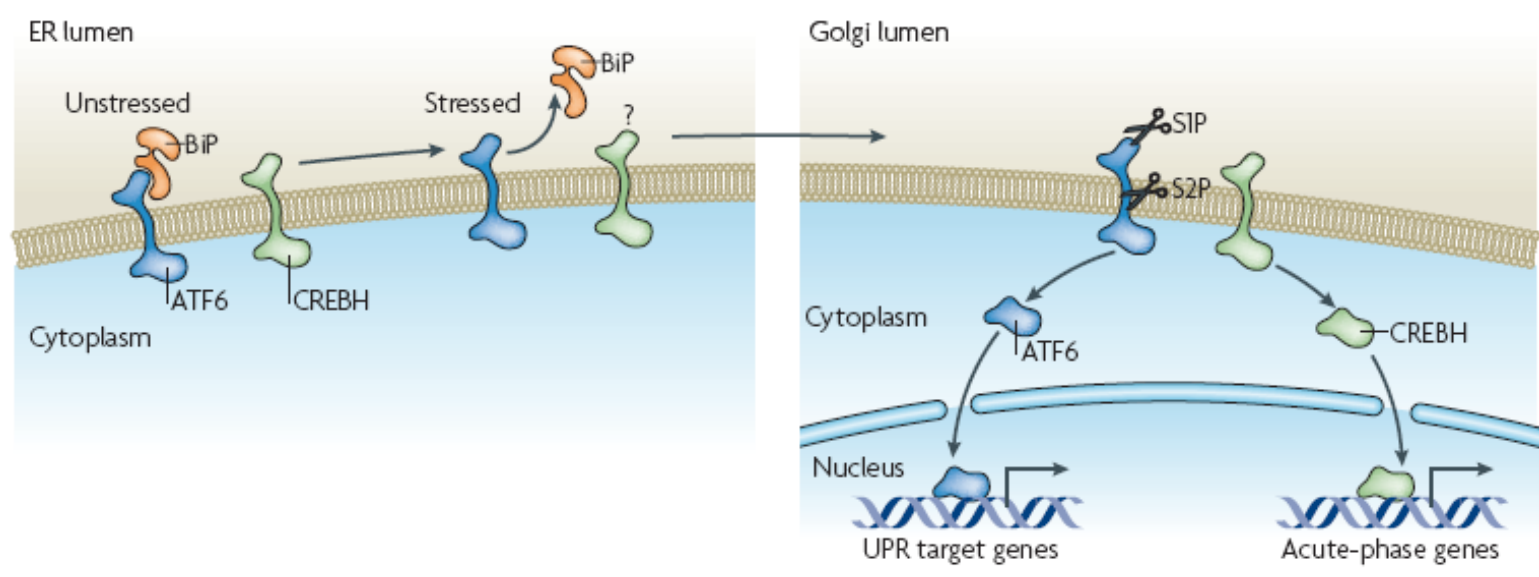

Em condições normais ATF6 e CREBH se localizam na membrana do RE. Em condições de estresse, Bip se dissocia de ATF6 para se ligar a proteínas mal formadas e impedir a agregação das mesmas. Essa dissociação faz com que ATF6 e CREBH sejam translocados para o Complexo de Golgi. Os detalhes dessa translocação ainda permanecem desconhecidos. No Complexo de Golgi, ATF6 é clivado pelas proteases S1P e S2P que libera a subunidade $\mathrm{ATF}_{50}$ que se transloca até o núcleo onde controla a transcrição de genes importantes na UPR. Fonte: (RON; WALTER, 2007)

O complexo da NADPH oxidase seria o terceiro componente envolvido no processo de morte em neutrófilos. Este é um complexo enzimático composto por proteínas citoplasmáticas $\left(\mathrm{p} 40^{\text {phox }}, \mathrm{p} 47^{\text {phox }}\right.$ e $\mathrm{p} 67^{\text {phox }}$ ) e proteínas de membrana (p22 phox e gp91 phox $)$, que constituem uma flavo-hemoproteína heterodímera conhecida como citocromo b $b_{558}$ (BABIOR, 1991; PARKOS et al., 1987). Esse complexo parece estar envolvido na morte celular devido a produção de EROs exarcebada, principalmente em neutrófilos, necessária para formação das NETs e, conseqüentemente, pelo processo de morte celular NETose. A ativação da NADPH oxidase é iniciada com a fosforilação e mudança conformacional da p47 phox , porém alguns estudos sugerem que apenas a fosforilação não seja suficiente para ativar o complexo enzimático. Dana et al. (1998) demonstraram que o ácido araquidônico gerado pela fosfolipase $\mathrm{A}_{2}$ citosólica foi essencial para a ativação completa da NADPH oxidase in vivo e, Shiose e Sumimoto (2000) verificaram que a ativação de $\mathrm{p} 47^{\text {phox }}$ requer uma ação sinérgica da fosforilação e do ácido araquidônico.

A ativação de $\mathrm{p} 47^{\text {phox }}$ promove a translocação das proteínas $\mathrm{p} 40^{\text {phox }}, \mathrm{p} 47^{\text {phox }}$ e $\mathrm{p} 67^{\text {phox }}$ para a membrana plasmática onde se associam ao citocromo b558. No complexo associado à membrana, a p47 phox parece estabilizar a interação da $\mathrm{p} 67^{\text {phox }}$ com o citocromo, que juntamente com a gp91 ${ }^{\text {phox }}$, formam o sítio catalítico ativo da enzima. Após a ativação completa da oxidase, inicia-se tanto a transferência de elétrons, como a geração de ânion superóxido. Em neutrófilos, estes processos são regulados e modificados por duas proteínas 
de baixo peso molecular, ligadoras de guanosina trifosfato (GTP): ras-related C3 botulinum toxin substrate 2 (Rac2) e member of RAS oncogene family (Rap1A) (ABO et al., 1991; KNAUS et al., 1991). Funcionando como molécula ativadora na cascata sinalizadora, a Rac permanece no citoplasma na sua forma inativa, quando ligada a GDP (Guanosine Diphosphate) e associada ao Guanine nucleotide Dissociation Inhibitor (RhoGDI). Na ativação do fagócito, a Rac-2 se liga a GTP, através da P-Rex-1 que atua como um Guaninenucleotide exchanche factor (GEF) para Rac-2 (WELCH et al., 2002), e se desloca para a membrana, associando-se às outras proteínas oxidases (ABO et al., 1994; QUINN et al., 1993). Além da Rac-2 induzir a atividade da NADPH oxidase pela fosforilação da $\mathrm{p} 47^{\text {phox }}$ (KNAUS; BOKOCH, 1995), esta interage com a p67 ${ }^{\text {phox }}$ (DIEKMANN et al., 1994) e com o citocromo b558 (HEYWORTH et al., 1994), modulando o complexo enzimático. A Rap-1A, que se associa ao citocromo b558 após a ativação da NADPH oxidase (QUINN et al., 1989), parece ser responsável pela ativação indireta do complexo enzimático ao ativar a proteína quinase C (GABIG et al., 1995; QUINN et al., 1995) (Figura 4).

Figura 4- Complexo enzimático NADPH oxidase.

$\mathbf{A}$

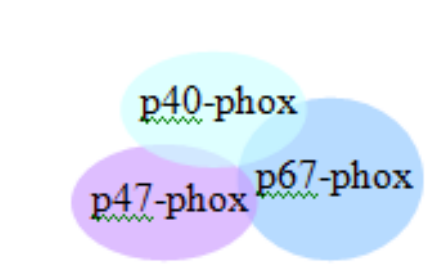

citocromo
Rac

GDP

\section{RhoGDI}
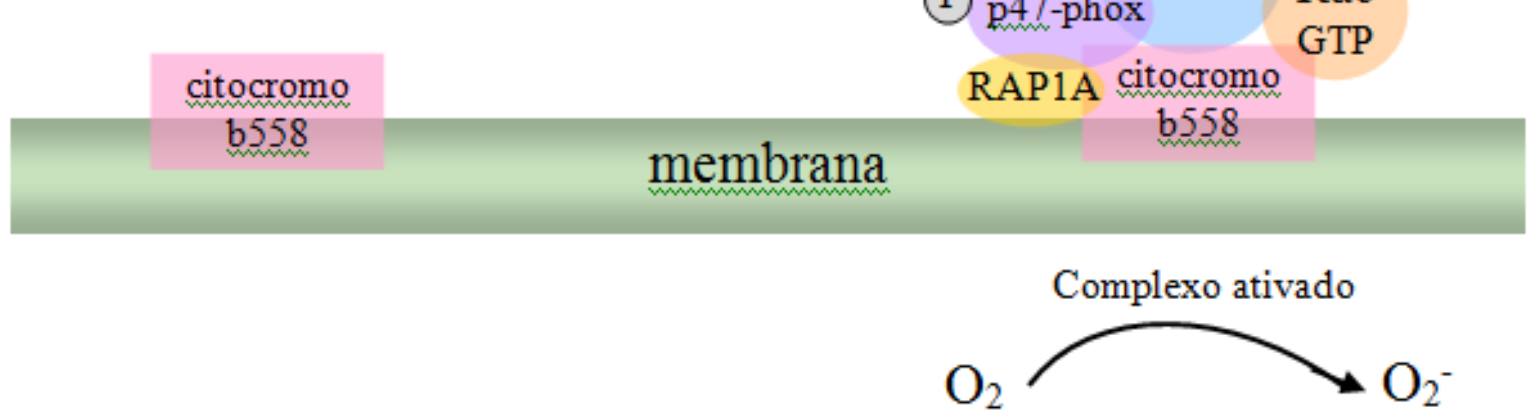

(A) Complexo enzimático NADPH oxidase composto por proteínas citoplasmáticas ( $\mathrm{p} 40^{\text {phox }}, \mathrm{p} 47^{\text {phox }}$ e $\mathrm{p} 67^{\text {phox }}$ ), citocromo b558 associado a RAP 1A e proteínas citoplasmáticas Rac-GDP e RhoGDI. (B) Complexo enzimático ativado após fosforilação (representada por "P") da proteína p47phox.

Fonte: (EMORY UNIVERSITY, 2013). 
A NADPH oxidase promove a transferência de elétrons do complexo para a molécula de oxigênio do fagossomo gerando o ânion superóxido, conforme a reação: $\mathrm{NADPH}+2 \mathrm{O}^{2} \rightarrow$ $\mathrm{NADP}^{+}+2 \mathrm{O}^{2-}+\mathrm{H}^{+}$. Esta transferência é um processo de várias etapas, e os elétrons passam através de molécula FAD e dois grupos heme, que fazem parte do citocromo b558 (DIEBOLD; BOKOCH, 2001; MEISCHL; ROOS, 1998), mas é a proteína citoplasmática p67 $7^{\text {phox }}$ que regula a transferência de elétrons após sua ativação (HAN et al., 1998; NISIMOTO et al., 1999).

O ânion superóxido não apresenta grande ação bactericida BABIOR; CURNUTTE; KIPNES, 1975; KLEBANOFF, 1974) e o peróxido de hidrogênio, que é formado pela dismutação espontânea ou dependente da enzima superóxido dismutase (SOD) do ânion superóxido (BABIOR; KIPNES; CURNUTTE, 1973), é bactericida somente em concentrações muito altas (IMLAY; LINN, 1986). A maior parte do peróxido de hidrogênio gerado por neutrófilos é consumida pela mieloperoxidase (KETTLE; WINTERBOURN, 1997; KLEBANOFF, 1992), enzima que catalisa a formação de HOCl por oxidação de íons cloreto (AGNER, 1972; HARRISON; SHULTZ, 1976), o principal oxidante bactericida produzido por neutrófilos (IYER; ISLAM; QUASTEL, 1961; KLEBANOFF, 1968). A reação do $\mathrm{HOCl}$ com aminas produz cloraminas que apresentam ação BACTERICIDA e prolongam a atividade oxidante do sistema peroxidase (BEILKE; COLLINS-LECH; SOHNL, 1989; DOMIGAN et al., 1995; GRISHAM et al., 1984; THOMAS; LEARN, 1991). Em 1894, Fenton descreveu a atividade oxidativa da mistura do sulfato de ferro e $\mathrm{H}_{2} \mathrm{O}_{2}$ e, em 1934, Haber e Weiss evidenciaram o $\mathrm{OH}$ - como um poderoso oxidante formado da seguinte maneira:

$\mathrm{H}_{2} \mathrm{O}_{2}+\mathrm{Fe}^{2+} \rightarrow \mathrm{Fe}^{3+}+\mathrm{OH}^{-}+\cdot \mathrm{OH}$, como em fluídos biológicos a concentração livre de ferro é limitada, a interação entre $\mathrm{H}_{2} \mathrm{O}_{2}$ e $\mathrm{O}_{2}{ }^{-*}$, para formar $\cdot \mathrm{OH}$, é então catalisada e limitada pela concentração livre de ferro. A reação de Haber-Weiss:

$\mathrm{H}_{2} \mathrm{O}_{2}+\mathrm{O}_{2}^{-*} \rightarrow \mathrm{O}_{2}+\mathrm{OH}^{-}+\cdot \mathrm{OH}$. Entretanto, menos de $1 \%$ de $\mathrm{H}_{2} \mathrm{O}_{2}$ e $\mathrm{O}_{2}^{--}$produzidos pelos neutrófilos pode formar o $\cdot \mathrm{OH}$ por este mecanismo (RAMOS et al., 1992) e, considerando que o radical hidroxil é extremamente reativo, reagirá com outra molécula antes de atingir seu alvo na membrana bacteriana, como o $\mathrm{CO}_{2}$, gerando o radical $\mathrm{HCO}_{3}$, podendo atuar como microbicida no fagossomo (LYMAR; HURST, 1995).

Os três componentes celulares - mitocôndria, RE e a NADPH oxidase - parecem atuar em conjunto para regulação da morte celular. Uma evidencia dessa associação é a aproximação física entre a mitocôndria e o RE conhecida como Mitochondria-Associated ER 
Membrane (MAM). A MAM tem fundamental participação na homeostase celular, incluindo o transporte não vesicular de fosfolipídios, transmissão de íons cálcio do RE para a mitocôndria para estimular o metabolismo oxidativo e o controle das concentrações de cálcio no lúmen do RE (HAJNOCZKY et al., 2003; RIZZUTO et al., 2004). Algumas proteínas são essenciais para que a interação entre essas duas organelas aconteça e dentre elas se encontram: a 44kDa Endoplasmatic reticulum protein (ERp44), ERp57, Calnexina, Calreticulina e ERO1-like $\alpha$ (Ero1 $\alpha$ ) (APPENZELLER-HERZOG et al., 2010), que regulam o fluxo de cálcio do RE por interações redox-dependentes com Inositol 1,4,5,-Triphosphate Receptors (IP3Rs) e com a Sarcoplasmatic/Endoplasmatic Reticulum Calcium ATPases (SERCA) (HIGO et al., 2005; LI; CAMACHO, 2004); 75kDa Glucose Regulated protein (GRP75) que é uma chaperona resposável pela ligação do Mitochondrial Voltage Dependent Anion Channel (VDAC) ao IP3R (SZABADKAI et al., 2006); a mitofusina-2, uma GTPase de membrana que estabiliza a interação RE-mitocôndria (CHEN et al., 2003, KOSHIBA et al., 2004); Phosphofurin acidic cluster sorting protein 2 (PACS-2), um dos responsáveis pela aproximação entre as mitocôndrias e o RE, por afetar a composição da MAM ao mediar a localização do canal de liberação de cálcio denominado de The Transiente Receptor Potential Protein 2 (TRPP2) (KOTTGEN et al., 2005; MYHILL et al., 2008); e o receptor sigma-1, responsável pela estabilização da ligação IPR3-grp75-VDAC (HAYASHI; SU., 2007) (Figura $5)$. 
Figura 5- Proteínas que participam na regulação da MAM.

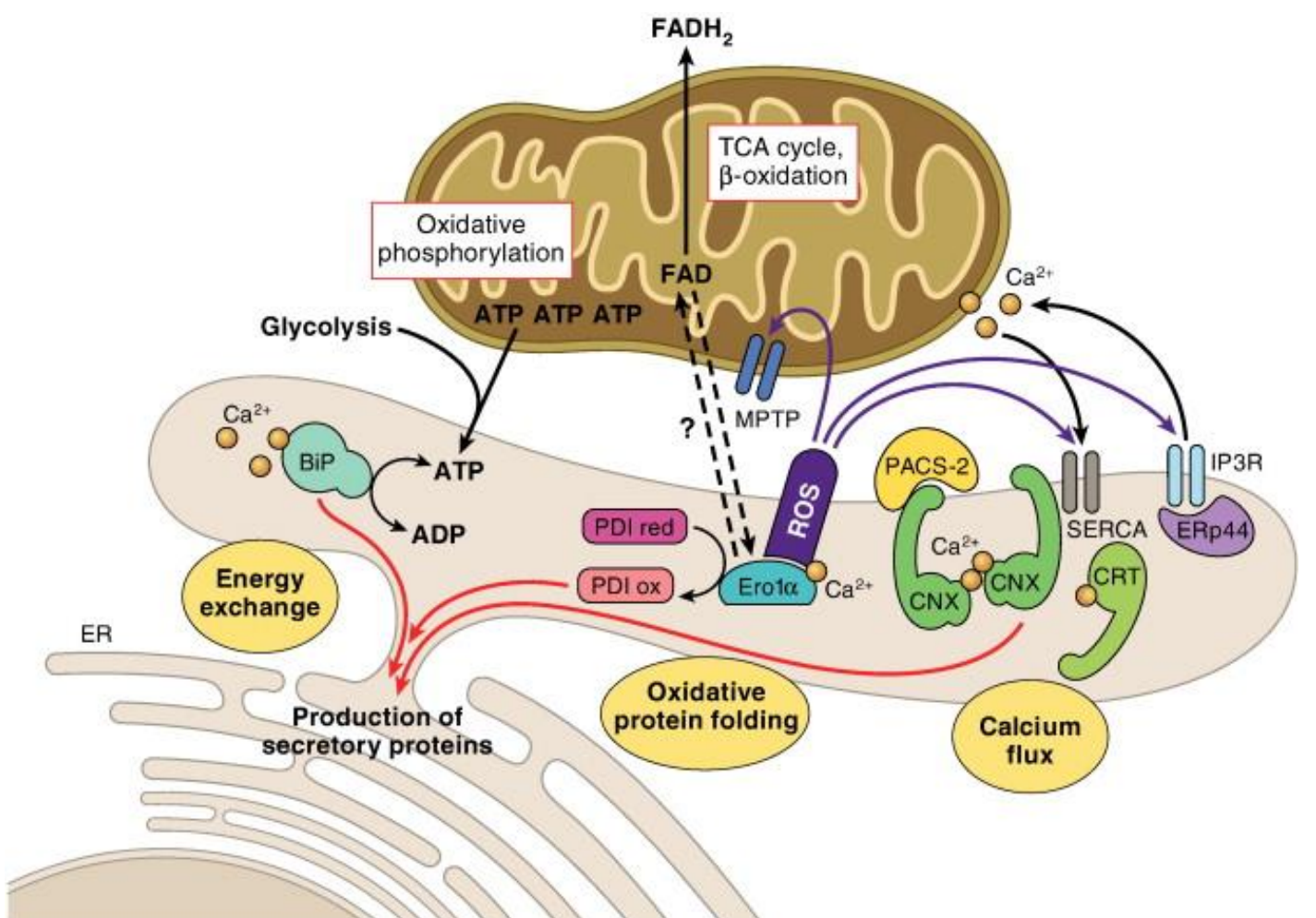

Influência das três maiores trocas metabólicas que acontece entre a mitocôndria e o RE no sistema de chaperonas do RE.

Fonte: (SIMMEN et al., 2010).

Qualquer alteração nessas proteínas e, consequentemente, na formação da MAM pode acarretar em danos e até morte celular. A distância entre o RE e a mitocôndria durante a formação da MAM deve ser preciso, pois o espaço menor que $5 \mathrm{~nm}$ entre essas organelas promove uma sobrecarga de $\mathrm{Ca}^{2+}$ na mitocôndria, prejudicando a função dessa organela. Aparentemente, a interface mitocôndria-RE, seria capaz de detectar a alteração da concentração de $\mathrm{Ca}^{2+}$ citosólico, podendo alterar dinamicamente a distância entre as organelas pararesposta celular adequada (CSORDAS et al., 2006). A NADPH oxidase, por sua vez, parece estar envolvida no processo de morte celular, pois é bem estabelecido que a exposição celular a EROs proveniente do complexo enzimático, podem promover a geração de EROs pela mitocôndria por alterar a permeabilidade da membrana mitocondrial e a função dos canais iônicos, além de desencadear mutações do DNA mitocondrial (WOSNIAK et al., 2009).

Dessa maneira, a morte celular parece depender da participação de vários componentes celulares e não apenas da ação de organelas isoladas. 


\section{JUSTIFICATIVA}

Recentemente verificou-se que há a possibilidade da participação do retículo endoplasmático no processo de morte celular. Essa organela pode apresentar-se sob condição de estresse devido a alterações na formação de proteínas, além de ser outro possível sítio de produção de EROs, além da NADPH oxidase e da própria mitocôndria, e exacerbar a cascata de reações decorrentes do estresse de RE que podem desencadear a morte. A interferência do diabetes mellitus na morte celular de neutrófilos ainda não é bem esclarecida. Dessa maneira esse estudo visa investigar o estado de ativação do retículo endoplasmático em neutrófilos de animais diabéticos e a possível correlação dessa organela no processo de morte dessas células. 


\section{OBJETIVOS}

Os objetivos específicos do estudo foram:

1. Avaliar a situação de estresse do retículo endoplasmático em neutrófilos de animais controle e diabéticos através de microscopia de fluorescência.

2. Verificar a expressão gênica de Bip, componentes da UPR (IRE-1, PERK e ATF-6) e do fator de transcrição (CHOP) através da técnica de PCR tempo real.

3. Avaliar o conteúdo das proteínas relacionadas a ativação do estresse de RE e da integridade da MAM: PERK, eIF2 $\alpha$, peIF2 $\alpha$, ATF4, CHOP, GADD34, ATF6, pJNK e mitofusina 2.

4. Verificar o Splicing de XBP1

5. Avaliar a produção de espécies reativas de oxigênio pelos neutrófilos através de quimioluminescência.

6. Atividade das caspases 3 e 9 em neutrófilos através de espectrofluorimetria. 


\section{MATERIAL E MÉTODOS}

\subsection{Animais}

Foram utilizados ratos Wistar (Rattus norvegicus, var. albinus) machos, com peso entre 180 e $220 \mathrm{~g}$ e idade de, aproximadamente, 2 meses procedentes do Biotério do Departamento de Fisiologia e Biofísica do Instituto de Ciências Biomédicas da Universidade São Paulo. Os animais foram mantidos em gaiolas coletivas (4 ratos/gaiola) em ambiente com temperatura de $23 \pm 2{ }^{\circ} \mathrm{C}$, sob ciclo claro/escuro de 12 horas e, tiveram livre acesso à água e alimento (Nuvilab CR1, Nuvital Nutrientes Ltda, Curitiba, PR).

\subsection{Indução ao Diabetes mellitus}

Para indução do Diabetes mellitus os animais receberam uma única injeção endovenosa de estreptozotocina $(65 \mathrm{mg} / \mathrm{kg})$ dissolvida em tampão citrato, $\mathrm{pH} \mathrm{4,2.} \mathrm{Animais}$ controle receberam volume equivalente de tampão citrato, pela mesma via. Os experimentos foram realizados 2 semanas após a injeção da droga diabetogênica. A glicemia foi determinada através de um monitor de glicose (Roche Diagnostics Corporation, IN, USA), utilizando-se amostras de sangue obtidas da extremidade da cauda dos animais. Foram utilizados somente animais com glicemia superior a $200 \mathrm{mg} / \mathrm{dL}$.

\subsection{Obtenção de células}

Os neutrófilos foram obtidos da cavidade peritoneal de ratos após a injeção intraperitoneal (i.p) de $10 \mathrm{~mL}$ de uma solução de glicogênio de ostra tipo II (1\%) em tampão fosfato-salina (PBS) $\left(\mathrm{NaCl} 137 \mathrm{mM}, \mathrm{KCl} 3 \mathrm{mM}, \mathrm{KH}_{2} \mathrm{PO}_{4} \cdot \mathrm{H}_{2} \mathrm{O} 1 \mathrm{mM}, \mathrm{Na}_{2} \mathrm{HPO}_{4} \cdot 7 \mathrm{H}_{2} \mathrm{O} 6\right.$ mM), pH 7,4 (RIMELE et al., 1988; STURM et al., 1989). Após 4 horas, os animais foram mortos por deslocamento cervical e a cavidade peritoneal foi lavada com $20 \mathrm{~mL}$ de PBS. As células obtidas com pipeta Pasteur plástica foram centrifugadas a $1200 \mathrm{rpm}$ durante 10 minutos a $4^{\circ} \mathrm{C}$ e, ressuspendidas em $1 \mathrm{~mL}$ de PBS. Da suspensão de células, contendo 95 a $98 \%$ de neutrófilos, uma alíquota de $10 \mu \mathrm{L}$ foi retirada para contagem em câmara de Neubauer. 


\subsection{Cultura celular}

Neutrófilos (5 x $\left.10^{5}-10^{6} / \mathrm{mL}\right)$ foram mantidos em meio RPMI 1640 contendo $1 \%$ de soro fetal bovino por 30 minutos. O meio foi suplementado com $25 \mathrm{mM}$ de Hepes, $2 \mathrm{mM}$ de glutamina, $24 \mathrm{mM}$ de bicarbonato de sódio, $100 \mu \mathrm{g} / \mathrm{mL}$ de estreptomicina e $100 \mathrm{UI} / \mathrm{mL}$ de penicilina. As células foram mantidas em estufa a $37{ }^{\circ} \mathrm{C}$, contendo $5 \%$ de $\mathrm{CO}_{2}$.

\subsection{Delineamento experimental}

Os neutrófilos foram ativados ou não com $20 \mathrm{nM}$ de Phorbol 12-Myristate 13-Acetate (PMA) por 60 minutos. PMA ativa PKC, que promove a formação do complexo NADPH oxidase e consequentemente a produção de EROs. O PMA promove o estímulo farmacológico direto, ou seja, sem ativação de receptores que poderiam contribuir para o processo de morte celular, tornando o estudo mais coeso. Dessa maneira, esse estudo priorizou a influência da produção de EROs na indução do estresse de retículo endplasmático e o possível envolvimento no processo de morte dos neutrófilos. A produção de EROs é uma resposta típica do neutrófilo à inflamação, que visa erradicar o agente invasor e que tem uma grande influencia na homeostasia do RE. Para determinação do tempo de estímulo foi realizada a curva de tempo-resposta com PMA (20 nM) que identificou após 1 h alteração do potencial transmembrânico mitocondrial, um dos primeiros indícios do processo de morte celular, sendo que em tempos subsequentes observou-se também diminuição da integridade de membrana celular e aumento da fragmentação de DNA. Como o intuito do projeto foi estudar a participação de RE, mitocôndria e NADPH oxidase na vigência do processo de morte celular e não o fim do mesmo, o período de $1 \mathrm{~h}$ para estímulo foi o determinado para as análises. Os grupos controle e diabético foram subdivididos em t0 (tempo zero), "No PMA" e PMA. No t0 os neutrófilos não foram submetidos à cultura, dessa maneira, logo após o lavado peritoneal foram submetidos às análises. O subgrupo "No PMA" representa neutrófilos mantidos em cultura por $1 \mathrm{~h}$, sem estímulo; e o subgrupo "PMA" representa os neutrófilos estimulados em cultura por 1h. Dessa maneira, as análises dos parâmetros que indicam a possível participação do estresse de retículo na morte de neutrófilos foram realizadas em células estimuladas ou não em todos os protocolos descritos a seguir. 


\subsection{Imunofluorescência para detecção do estresse de RE}

Neutrófilos $\left(2 \times 10^{6}\right)$ foram incubados durante 30 minutos a $37^{\circ} \mathrm{C}$ com Hank's Ballanced Salt Solution (HBSS) (140 mM NaCl; 5,37 mM KCl; 1,26 mM CaCl $2.2 \mathrm{H}_{2} \mathrm{O} ; 0,81$

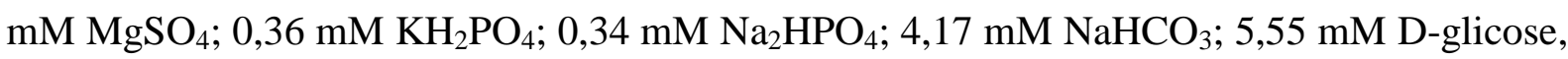
2,00 mM Glutamina, pH 7,4) e $1 \mu \mathrm{M}$ de ER-tracker ${ }^{\mathrm{TM}}$ Blue-White DPX (Molecular Probes). Logo após, células foram lavadas com HBSS e ressuspendidas em meio de cultura. Em seguida, os neutrófilos foram plaqueados sobre lamínulas previamente tratadas com Histogrip $^{\mathrm{TM}}$ e receberam ou não estímulo com PMA (20 nM). Após uma hora de incubação, lamínulas foram lavadas com HBSS e as células avaliadas através de microscópio de fluorescência (Aristoplan, Leitz, Germany).

\subsection{PCR em tempo real}

\subsubsection{Extração de RNA}

O RNA total de neutrófilos foi obtido de $1,5 \times 10^{7}$ células pelo método de extração com isotiocianato de guanidina (CHOMCZYNSKI; SACCHI, 1987), usando o reagente TRIzol ${ }^{\circledR}$ (Invitrogen, Carlsbad, CA, USA). As células foram lisadas com TRIzol que mantém a integridade do RNA, enquanto rompe membrana e todos os componentes celulares. Inicialmente, as amostras homogeneizadas foram incubadas por 5 minutos à temperatura ambiente para permitir dissociação completa dos complexos nucleoproteicos. Foi adicionado clorofórmio $(0,2 \mathrm{~mL})$ e centrifugado a $12.000 \mathrm{x} g$ por 15 minutos, a $4^{\circ} \mathrm{C}$. A fase aquosa foi transferida e o precipitado de RNA foi obtido por centrifugação (12.000 x $g$, por 10 minutos, a $4^{\circ} \mathrm{C}$ ) após adição de 0,5 mL de isopropanol (CHOMCZYNSKI, 1993). O pellet de RNA foi lavado com etanol a $75 \%$ e centrifugado a 7.500 x g por 5 minutos, a $4{ }^{\circ} \mathrm{C}$. Finalmente, o pellet de RNA foi seco à temperatura ambiente, ressuspenso em água livre de RNase e armazenado a $\quad-70{ }^{\circ} \mathrm{C}$. A quantificação e pureza do RNA foram realizadas por espectrofotometria na absorbância de 260/280 nm. 


\subsubsection{Reação transversa $(R T)$}

O RNA $(1,5 \mu \mathrm{g})$ foi tratado com $1 \mathrm{U}$ DNase I, por 15 minutos, à $25^{\circ} \mathrm{C}$ e inativado com $25 \mathrm{mM}$ EDTA, por 10 minutos, à $65^{\circ} \mathrm{C}$. Em seguida, o cDNA foi sintetizado em $20 \mu \mathrm{L}$ de uma mistura de reagentes contendo $10 \mathrm{mM}$ dNTP Mix (10 mM cada dATP, dGTP, dCTP e dTTP), 0,1 M DTT (Invitrogen, Carlsbad, CA, USA) e $200 \mathrm{U}$ da Thermo Scientific Maxima ${ }^{\mathrm{TM}}$ Reverse transcriptase - Fermentas, à $42^{\circ} \mathrm{C}$, por 50 minutos. A reação foi inativada por aquecimento, à $70^{\circ} \mathrm{C}$, por 15 minutos.

\subsubsection{Real Time Polymerase Chain Reaction (Real time PCR)}

A expressão gênica da chaperona Bip (GRP78), dos sensores de estresse de RE (IRE1, PERK e ATF-6), proteínas da MAM (Mitofusina 2, GRP75, PACS2), razão Bax/Bcl2 e do fator de transcrição CHOP foi avaliada por PCR “real-time”(Tabela 1) (HIGUCHI et al., 1992) em um equipamento Rotor Gene 6000 (Corbett Research, Mortlake, Australia), com o uso do kit Sigma $S Y B R^{\circledR}$ Green Taq ReadyMix ${ }^{T M}$ que contém SYBR ${ }^{\circledR}$ Green I como sonda fluorescente. A quantificação da expressão gênica foi calculada por $2^{-\Delta \Delta C T}$ (LIVAK; SCHMITTGEN, 2001; PFAFFL, 2001), utilizando a expressão do gene Ribosomal Protein S6 como controle padrão.

Tabela1-Sequências de primers, temperatura de anelamento e tamanho do produto dos genes estudados.

(Continua)

\begin{tabular}{|c|c|c|c|}
\hline Genes & Primers & $\begin{array}{l}\text { Temperatura de } \\
\text { anelamento }\left({ }^{\circ} \mathrm{C}\right)\end{array}$ & $\begin{array}{c}\text { Tamanho do } \\
\text { produto do } \\
\text { PCR (pb) }\end{array}$ \\
\hline $\begin{array}{l}\text { ATF6 } \\
\text { NM_001107196 }\end{array}$ & $\begin{array}{l}\text { Sense: TGAAGTGGAAAGGACCAAATCG } \\
\text { Anti: AGAGCACCCTGGAGAATGCG }\end{array}$ & 56 & 72 \\
\hline $\begin{array}{l}\text { BIP (GRP78) } \\
\text { NM_013083 }\end{array}$ & $\begin{array}{l}\text { Sense : GACGCACTTGGAATGACCCTTC } \\
\text { Anti : TGGCAAGAACTTGATGTCCTGC }\end{array}$ & 50 & 57 \\
\hline $\begin{array}{l}\text { Bax } \\
\text { NM_017059.1 }\end{array}$ & $\begin{array}{l}\text { Sense: GACACTGGACTTCCTCCGTGAG } \\
\text { Anti: AGCCACCCTGGTCTTGGATC }\end{array}$ & 55 & 56 \\
\hline
\end{tabular}


Tabela1- Sequências de primers, temperatura de anelamento e tamanho do produto dos genes estudados.

(Conclusão)

\section{Bcl2}

NM_016993.1 Sense: GTGGACAACATCGCTCTGTGG Anti: CATCCCAGCCTCCGTTATCC $\quad 56 \quad 82$

CHOP

NM_001109986 Sense : ACGGAAACAGAGTGGTCAGTGC Anti :TGCTCCTTCTCCTTCATGCG $\quad 55$

GRP75

NM_001100658.1 Sense: TGGCTGTTATGGAGGGCAAAC Anti: GGTAGTTCTGGCACCTTCGGAG $\quad 57 \quad 62$

IRE1

NM_001191926 Sense: TGTGGAGCAGAAGGACTTCGC Anti: TCTGATGAAGCAAGGTGATGGG $\quad 57 \quad 59$

Mitofusin 2

NM_130894

Sense : CAACTCCATCGTCACCGTCAAG Anti : TCACCTCAGCCATGTGTCGC

\section{PACS2}

NM_134406.1

Sense : ACGGAGATCGGCAGTCTCAAC

Anti : TTCCATAGGGCTGGTGGTGTC

\section{PERK}

NM_031599.1

Sense : CAAGCCAGAGGTGTTTGGGAAC Anti : TCTCCGTCCAGGGAAGGAATG

\section{S6}

Sense: GCAGATGGATGTGACAACGAGC

NM_031985

Anti: GCTGTCGGATTGGAAGTGGC

XBP1

\subsubsection{XBP-1 mRNA Splicing}

O cDNA XBP-1 de rato foi amplificado por RT-PCR (Qiagen OneStep RT-PCR kit) utilizando-se de primers que se ligam antes do íntron que é excisado pela atividade exonuclease do IRE1. Dessa maneira, os primers conseguem sintetizar o cDNA do mRNA correspondente ao IRE1 inteiro e clivado. As sequências dos primers para amplificar XBP-1 e sXBP1 de rato foram: 5’AAA CAG AGT AGC AGC ACA GAC TGC 3’ e 5' TCC TTC TGG GTA GAC CTC TGG GAG 3'. O protocolo para RT-PCR foi o seguinte: $50{ }^{\circ} \mathrm{C}(30$ $\min ) ; 95{ }^{\circ} \mathrm{C}(15 \mathrm{~min}) ; 35$ ciclos de $\left\{94{ }^{\circ} \mathrm{C}(1 \mathrm{~min}), 60{ }^{\circ} \mathrm{C}(1 \mathrm{~min}), 72{ }^{\circ} \mathrm{C}(1 \mathrm{~min})\right\}$ e $72{ }^{\circ} \mathrm{C}(10$ min). Os cDNAs produzidos pelo RT-PCR foram submetidos à eletroforese em um gel de agarose $3 \%$ e visualizados utilizando-se obrometo de etídio. 


\subsection{Western Blotting}

A análise de western blotting foi realizada conforme descrito anteriormente (OHIRA et al., 2004; OMORI et al., 2004). Neutrófilos $\left(1 \times 10^{7}\right)$ foram rapidamente lisados pela adição de $60 \mu \mathrm{L}$ de tampão 1\% Triton X100 com 1\% (v/v) cocktail inibidor de protease (SigmaAldrich) e $1 \mathrm{mM}$ PMSF. Alíquotas destas amostras foram separadas por SDS-PAGE (30 $\mu \mathrm{g} /$ poço). As proteínas separadas foram transferidas, eletroforeticamente, para membranas de nitrocelulose utilizando tampão Tris-borato [25 mM Tris, $192 \mathrm{mM}$ glicina e 20\% (v/v) metanol, $\mathrm{pH}$ 8,4] (TOWBIN et al., 1979). Proteínas foram transferidas a $100 \mathrm{~V}$ por 150 minutos a $4{ }^{\circ} \mathrm{C}$. As membranas foram bloqueadas por $1 \mathrm{~h}$ a temperatura ambiente com $5 \%$ de leite desnatado ( $\mathrm{pH}$ 7,6). O tampão de bloqueio foi removido e as membranas foram incubadas com os anticorpos primários apropriados (PERK, eiF2 $\alpha$, peIF2 $\alpha$, ATF4, CHOP, GADD34, pJNK, ATF6, mitofusina 2) overnight a $4{ }^{\circ} \mathrm{C}$ em $20 \mathrm{mM}$ Tris $\mathrm{HCl}(\mathrm{pH} 7,6)$ contendo $250 \mathrm{mM} \mathrm{NaCl}, 0,1 \%$ (v/v) Tween 20, 1\% (w/v) BSA e 0,002\% (w/v) NaN3. As membranas foram subsequentemente lavadas três vezes (10 min. por lavagem) com TBST [20 $\mathrm{mM}$ Tris- $\mathrm{HC} 1(\mathrm{pH} 7,6)$ contendo $150 \mathrm{mM} \mathrm{NaCl}$ e $0,1 \%$ (v/v) Tween 20] e então incubadas com os anticorpos secundários (goat anti-mouse ou rabbit IgG-HRP conjugada) em TBST por $1 \mathrm{~h}$ a temperatura ambiente. As membranas foram lavadas três vezes em TBST. A atividade da HRP foi visualizada pela incubação das membranas por 5 minutos à temperatura ambiente com sistema de detecção ECL (Pierce), seguido de autoradiografia. Ao término dos experimentos, os blots foram normalizados pela membrana corada com ponceau como previamente descrito por Romero-Calvo et al. em 2010 e Aldridge et al. 2008 (APÊNDICE A). A densidade das bandas foi determinada através do software Image J (NIH).

\subsection{Produção de Espécies Reativas de Oxigênio}

A mistura de reação contendo $200 \mu \mathrm{L}$ de tampão HBSS, $500 \mu \mathrm{M}$ de Luminol, inibidores da NADPH oxidase e PKC, $10 \mu \mathrm{M}$ Diphenylene iodonium (DPI) (LIU; ZWEIER, 2001) e 0,2 $\mu$ M GF109203X (GFX) (KAWAKAMI et al., 2000), e 1 x $10^{6}$ neutrófilos/ml foi submetida a uma leitura cinética por $45 \mathrm{~min}$ em intervalos de 3 minutos. A leitura de quimiluminescência foi feita através do leitor de microplacas (Sinergy HT, Biotek, USA). O controle negativo foi composto somente por mistura de reação e a reação foi iniciada ao adicionar $10 \mu \mathrm{L}$ de PMA (160 nM). 


\subsection{Atividade de caspases por espectrofluorescência}

A atividade da caspase 3 foi avaliada através do espectrofluorímetro da Biotek (Sinergy HT, USA) conforme descrito na seqüência. Neutrófilos foram ressuspendidos e homegeneizados em $50 \mu \mathrm{L}$ de tampão de lise. As células foram incubadas por 10 minutos a $4{ }^{\circ} \mathrm{C}$ e, em seguida, $50 \mu \mathrm{L}$ de tampão de reação contendo $10 \mathrm{mM}$ ditiotreitol (DTT) foi adicionado em cada amostra. Em seguida, $5 \mu \mathrm{L}$ de substrato $(50 \mu \mathrm{M})$ [ caspase 3 (DEVDAFC - AFC: 7-amino-4-trifluoromethyl coumarin)] foi adicionado no ensaio e as amostras incubadas a $37^{\circ} \mathrm{C}$ por 2 horas (BioVision Corporate, Califórnia, USA) . A atividade da caspase foi determinada pela avaliação da fluorescência de AFC emitida após a clivagem do substrato pela respectiva caspase. O AFC livre emite fluorescência no $\chi$ máximo de $505 \mathrm{~nm}$ (ANDERSON et al., 2000).

\subsection{Análise estatística}

Os resultados foram avaliados por análise de variância two-way-ANOVA seguida pós teste de Bonferroni. Foi considerado significativo $\mathrm{p}<0,05$. 


\section{RESULTADOS}

Os animais diabéticos apresentaram perda de peso, aumento significativo da glicemia e menor número de neutrófilos obtidos do lavado peritoneal quando comparados aos animais controle (Figura 6)

Inicialmente verificou-se qualitativamente o estresse de RE em neutrófilos de animais controles e diabéticos. Para tanto as células foram marcadas com ER-tracker ${ }^{\mathrm{TM}}$ Blue-White DPX (Molecular Probes), uma sonda fluorescente capaz de detectar alterações morfológicas no RE, sendo que quanto maior a intensidade e frequência de fluorescência, maior a influência do estímulo na integridade da organela, podendo ser um indicativo de estresse. Pôde-se observar uma maior frequência e intensidade de fluorescência em neutrófilos de animais diabéticos não estimulados e após PMA (Figuras 7C e 7G) quando comparado com o grupo controle não estimulado e após PMA, respectivamente (Figuras $7 A$ e $7 E$ ), indicando o aumento de estresse de RE tanto em neutrófilos de animais diabéticos em estado basal como quando estimulados.

Com o objetivo de investigar a ativação da UPR, foi avaliada a expressão de genes envolvidos na homeostasia do RE. Com relação a chaperona Bip (GRP78), verificou-se aumento de sua expressão em neutrófilos de ratos controle após estímulo com PMA em relação ao t0; no entanto, esse aumento não foi observado em neutrófilos do grupo diabético (Figura 8). Os três componentes da UPR também foram avaliados por qPCR, com relação ao IRE1 $\alpha$ verificou-se aumento de sua expressão em neutrófilos do grupo diabético estimulados ou não com PMA quando comparado ao t0 diabético, enquanto que no grupo controle só houve aumento no grupo estimulado com PMA (Figura 9A). A expressão gênica de PERK (Figura 9B) e ATF6 (Figura 9C) não alterou significativamente nos grupos estudados. O fator de transcrição CHOP, que está diretamente ligado à morte celular por estresse de RE, teve sua expressão aumentada tanto em neutrófilos de animais controles quanto de animais diabéticos após estímulos com PMA. Células provenientes de animais diabéticos que permaneceram por 1h em cultura já apresentaram maior expressão de CHOP quando comparados aos neutrófilos em t0 (Figura 10). A avaliação dos possíveis componentes celulares envolvidos no processo de morte dos neutrófilos culmina na verificação da formação da MAM e de suas proteínas reguladoras, como a Mitofusina-2, PACS2 e GRP75. A expressão gênica de mitofusina-2 está aumentada em células oriundas de animais controle após estímulo com PMA quando comparadas às células nas condições t0 e No PMA. Já em neutrófilos de animais diabéticos, 
não se observou qualquer alteração na expressão deste gene (Figura 11A). Com relação a expressão gênica de PACS2, não se observou diferença significativa entre os grupos estudados (Figura 11B).Verificou-se diminuição da expressão gênica de GRP75 nos neutrófilos dos animais diabéticos após estimulo com PMA quando comparado com o grupo controle (Figura 11C). Os resultados observados indicam comprometimento na interação entre mitocôndria e RE dos neutrófilos de animais diabéticos. A razão da expressão gênica Bax/Bcl2 também é um indicativo da ativação de genes anti e pró-apoptóticos e esta se encontra aumentada em neutrófilos de ratos diabéticos quando comparado com o grupo controle, indicando uma maior suceptibilidade das células provenientes do grupo diabético a morte (Figura 12).

A análise do conteúdo de proteínas da via da PERK não indicou diferença significativa entre os grupos estudados quanto as proteínas PERK, eIF2 $\alpha$, ATF4 e GADD34 (Figura 13A, B,D e F). No entanto, a fosforilação de eIF2 $\alpha$ no subgrupo "No PMA" mostrou-se elevada no grupo controle quando comparado com o grupo diabético (Figura 13C), o memso observado na relação peIF2 $\alpha /$ IF $2 \alpha$. O conteúdo de CHOP mostrou-se elevado em ambos os grupos no T0 e diminuído no diabético após estímulo com PMA (Figura 13E).

Para analisar a via do IRE1 $\alpha$ foi feito o ensaio do splicing do XBP1 através de RTPCR, no qual se verificou que há o splicing de XBP1 em ambos os grupos e em todas as condições estudadas, indicando a possível ativação basal dessa via e a não interferência do estímulo PMA no splicing desse mRNA (Figura 14A). A fosforilação de JNK acontece na ativação de IRE1 $\alpha$ por uma via independente do splicing de XBP1 em situações de estresse de RE crônico. Observou-se o aumento da fosforilação dessa proteína em neutrófilos provenientes do grupo diabético estimulados ou não com PMA, tanto quando comparado aos neutrófilos em t0 do grupo diabético, como quando comparado aos neutrófilos provenientes do grupo controle estimulado ou não com PMA. (Figura 14B).

O conteúdo de ATF6 não alterou nos grupos e condições estudadas. (Figura 15). O conteúdo de mitofusina 2, uma proteína essencial na interação entre mitocôndria e RE, mostrou-se elevado nos grupos estimulados com PMA, porém não houve diferença significativa entre os grupos controle e diabético (Figura 16).

Com relação à produção de espécies reativas de oxigênio, avaliada através de quimioluminescência, não houve diferença significativa entre os grupos e condições estudadas, mesmo quando avaliada a produção na presença de inibidores da NADPH oxidase e de PKC, DPI e GFX, respectivamente. (Figura 17A). 
Neutrófilos provenientes de animais diabéticos apresentam aumento de $40 \%$ na atividade de caspase 3 quando comparado às células oriundas de animais controle, ambos sob estímulo de PMA.

Figura 6- Ganho de peso (A), Glicemia (B) e Número de neutrófilos (C) dos grupos estudados.

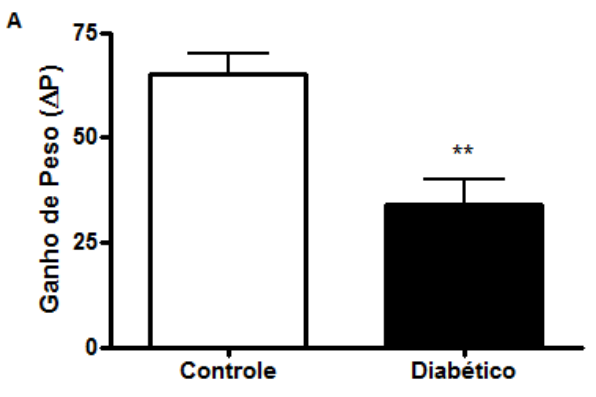

B

C
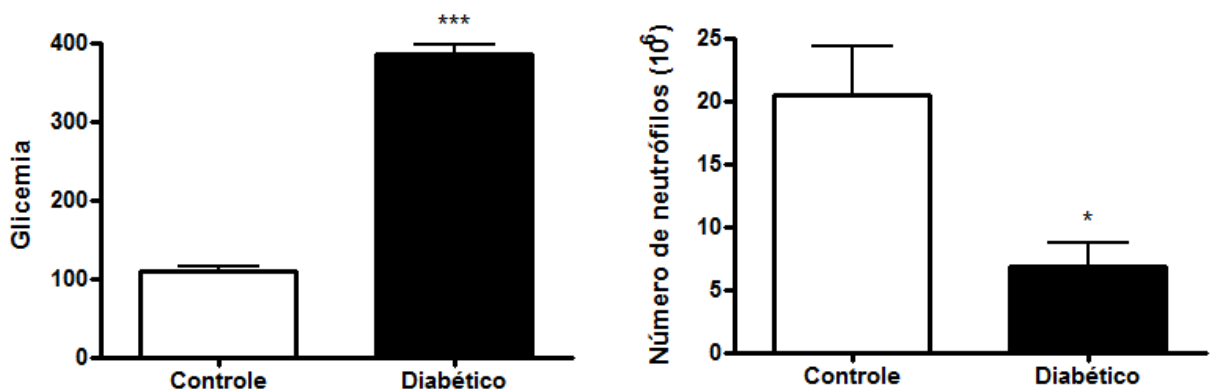

Diabetes foi induzido por estreptozotcina $(65 \mathrm{mg} / \mathrm{Kg}$, i.v. $)$ e os animais permaneceram nessa condição por 2 semanas. A glicemia foi determinada em animais alimentados $24 \mathrm{~h}$ antes do sacrifício dos animais. O número de neutrófilos refere-se a quantidade de células obtidas no lavado peritoneal 4h após a injeção de glicogênio de ostra (1\%). Os valores são apresentados pelas médias \pm e.p.m. $(n=12)$. $* \mathrm{p}<0.05 ; * * \mathrm{p}<0.01 \mathrm{e}^{* * *} \mathrm{p}<0.001$. 
Figura 7- Fotomicrografia de neutrófilos para detecção de estresse de RE através de imunofluorescência.
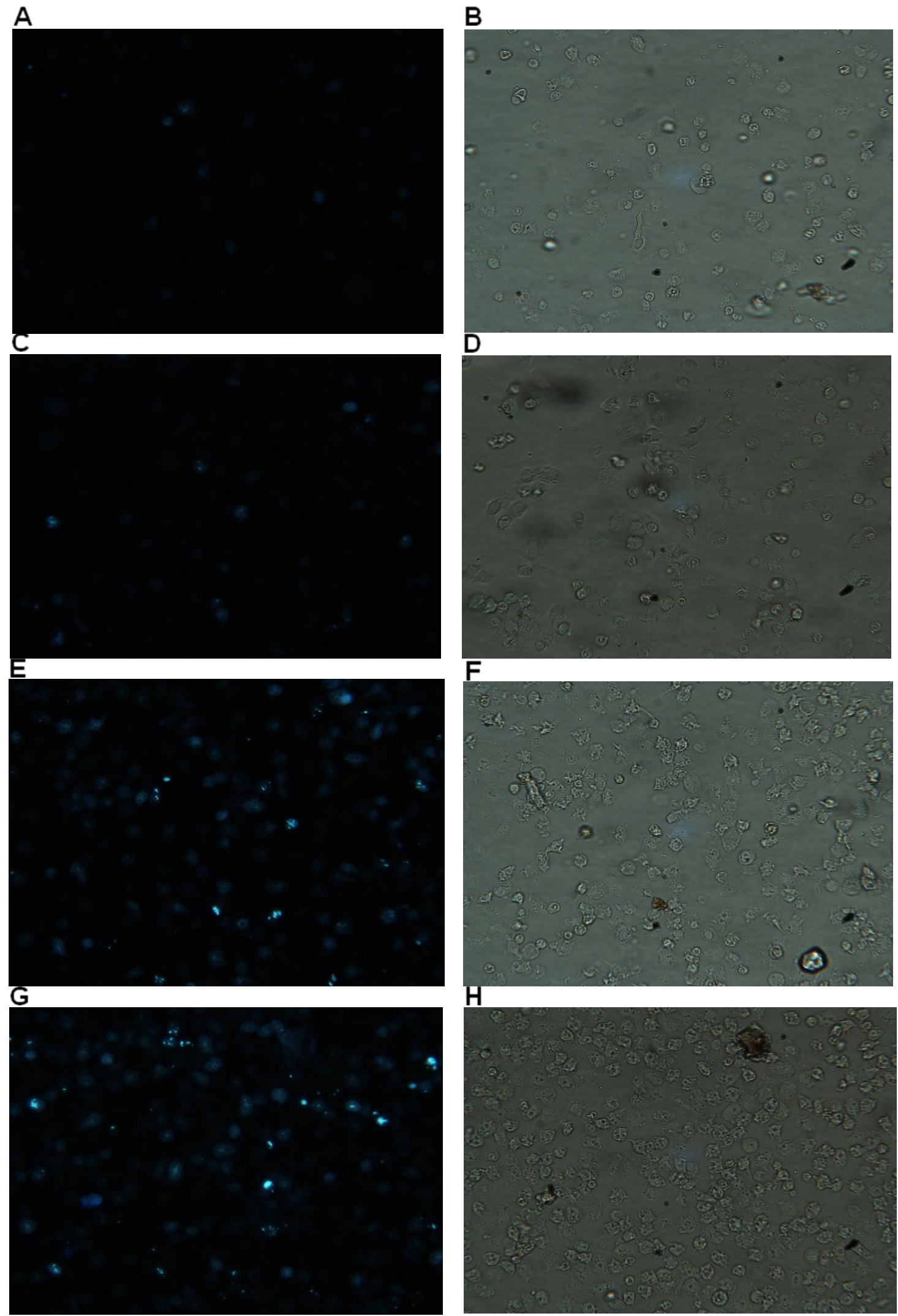

Grupos estudados: controles $(n=8)$ e diabéticos $(n=8)$. Neutrófilos de animais controles e diabéticos na ausência de estímulo (A e C) ou após estímulo com $20 \mathrm{nM}$ de PMA por 1 hora (E e G). Imagens em A,C,E e G foram adquiridas por fluorescência. B, D, F e H imagens de campo claro das amostras A, C, E e G, respectivamente. (Aumento 400x). 
Figura 8- Expressão gênica da chaperona GRP78 (BIP) por qPCR.

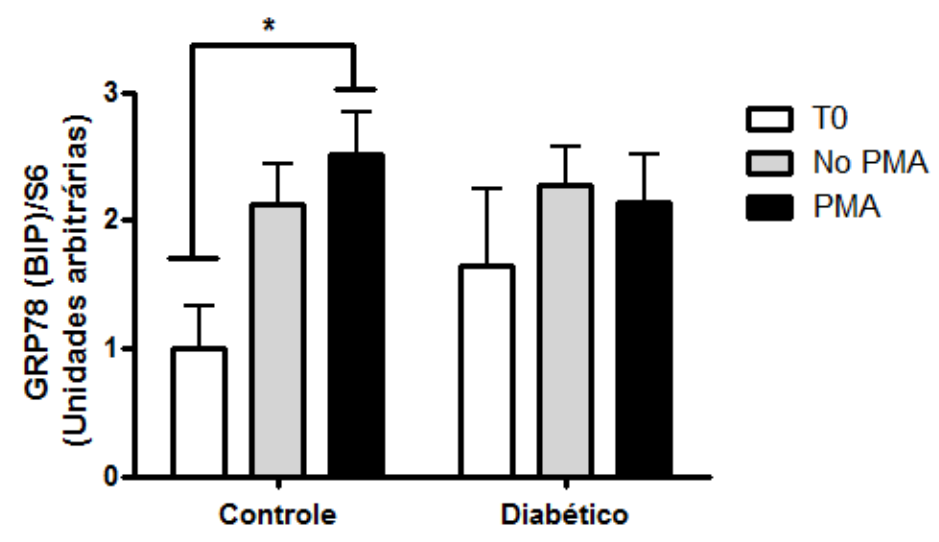

O diabetes mellitus foi induzido pela injeção de STZ (65 mg/Kg, i.v.) 2 semanas antes. Os neutrófilos foram obtidos do lavado peritoneal 4 horas após injeção de solução de glicogênio de ostra tipo II (1\%). Grupos estudados: controles $(n=11)$, diabéticos $(n=11)$, nas seguintes condições: tempo zero (T0) e estimulados ou não com PMA (20 nM). S6 foi utilizado com gene normalizador. * p $<0,05$.

Figura 9- Expressão gênica dos componentes da UPR: IRE1- $\alpha$ (A), PERK (B) e ATF6 (C) por qPCR.

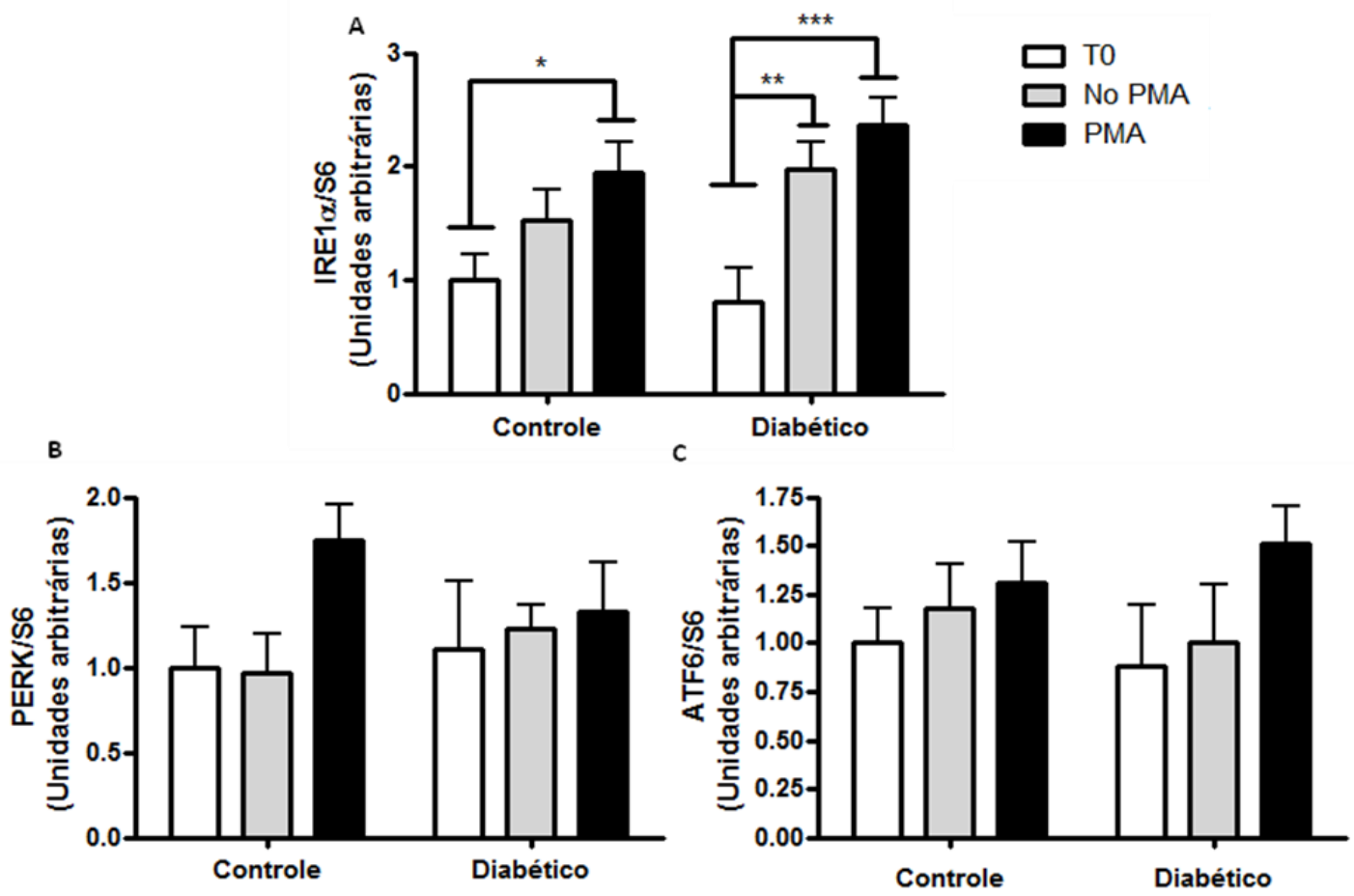

O diabetes mellitus foi induzido pela injeção de STZ (65 mg/Kg, i.v.) 2 semanas antes. Os neutrófilos foram obtidos do lavado peritoneal 4 horas após injeção de solução de glicogênio de ostra tipo II (1\%). Grupos estudados: controles $(n=11)$ e diabéticos $(n=11)$, nas seguintes condições: tempo zero (T0) e estimulados ou não com PMA (20 nM). S6 foi utilizado como gene normalizador. * $\mathrm{p}<0,05 ; * * \mathrm{p}<0,01 ; * * * \mathrm{p}<0,001$. 
Figura 10- Expressão gênica do fator de transcrição CHOP por qPCR.

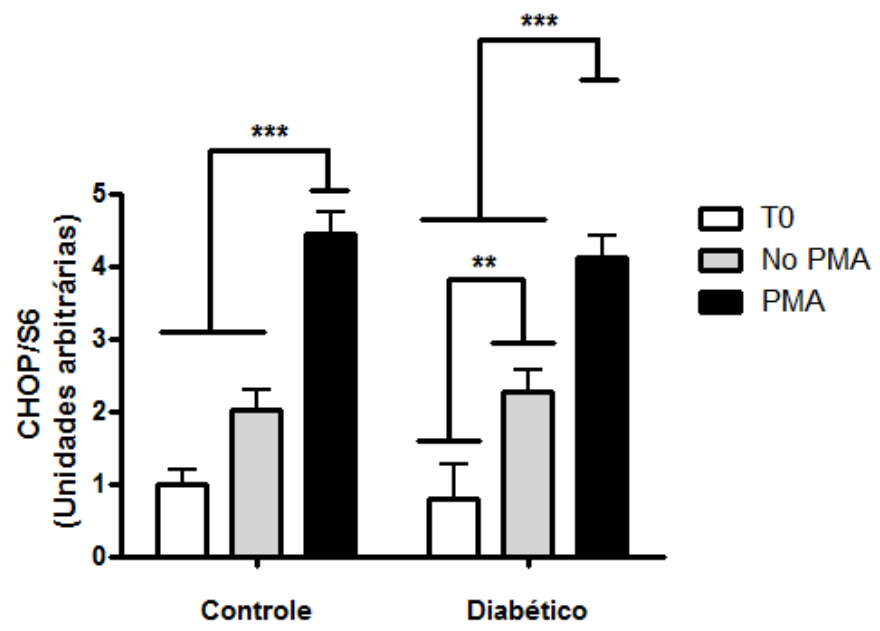

O diabetes mellitus foi induzido pela injeção de STZ (65 mg/Kg, i.v.) 2 semanas antes. Os neutrófilos foram obtidos do lavado peritoneal 4 horas após injeção de solução de glicogênio de ostra tipo II (1\%). Grupos estudados: controles $(n=11)$ e diabéticos $(n=11)$, nas seguintes condições: tempo zero $(T)$ e estimulados ou não com PMA (20 nM). S6 foi utilizado como gene normalizador. ** $\mathrm{p}<0,01$; *** $\mathrm{p}<0,001$.

Figura 11- Expressão gênica dos das proteínas reguladoras da MAM: Mitofusina-2 (A), PACS2 (B) e GRP75 (C) por qPCR.

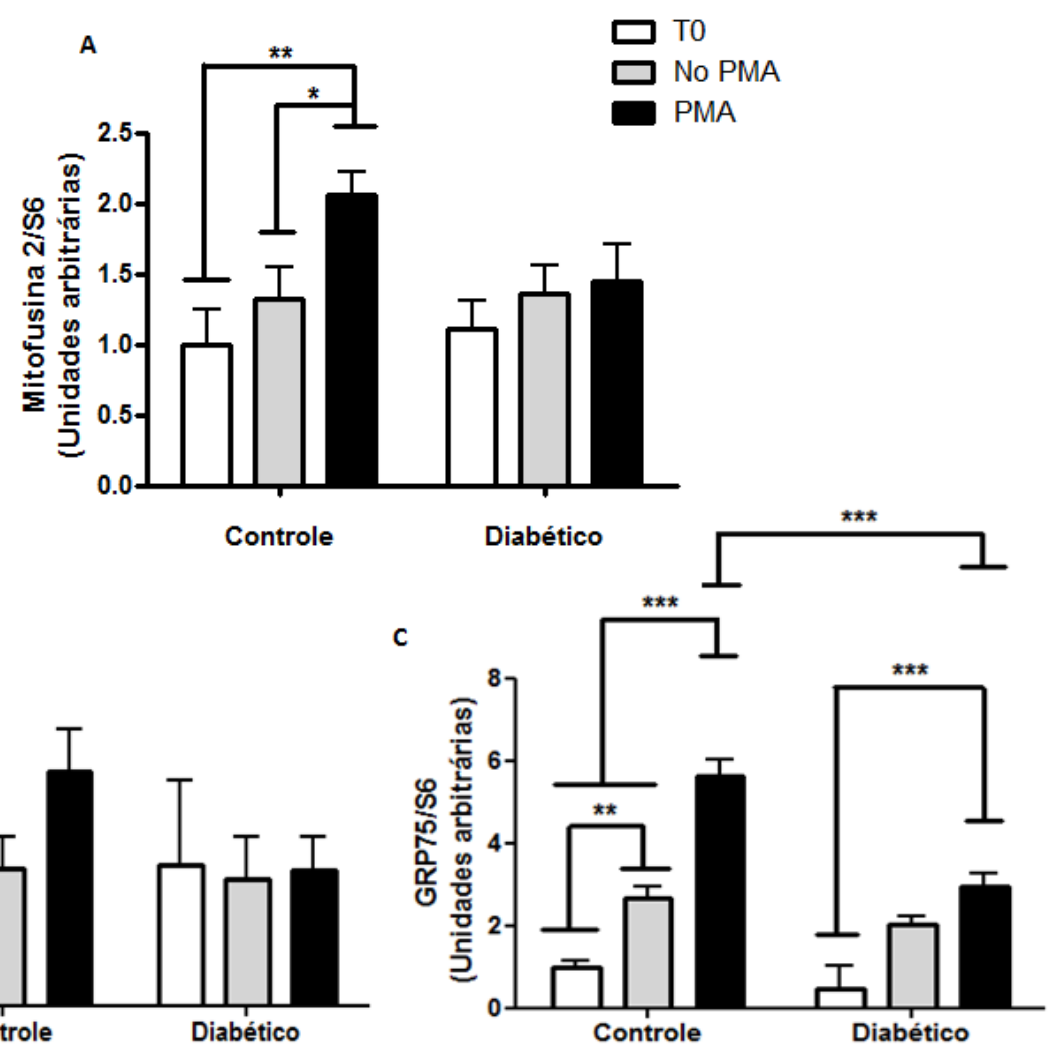

O diabetes mellitus foi induzido pela injeção de STZ (65 mg/Kg, i.v.) 2 semanas antes. Os neutrófilos foram obtidos do lavado peritoneal 4 horas após injeção de solução de glicogênio de ostra tipo II (1\%). Grupos estudados: controles $(n=11)$ e diabéticos $(n=11)$, nas seguintes condições: tempo zero e estimulados ou não com PMA (20 nM). S6 foi utilizado como gene normalizador. * $\mathrm{p}<0,05 ; * * \mathrm{p}<0,01 ; * * * \mathrm{p}<0,001$. 
Figura 12- Expressão gênica da razão Bax/Bcl2 por qPCR.

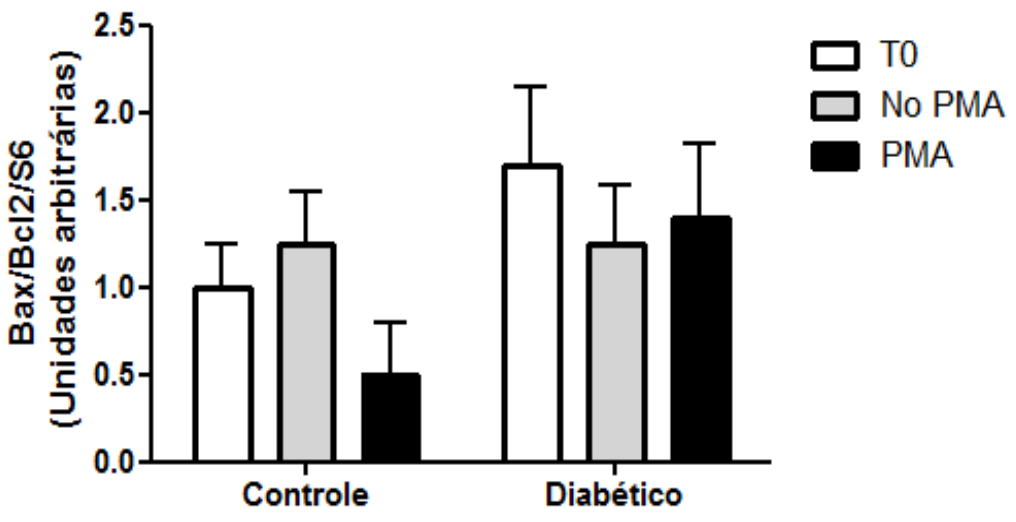

O diabetes mellitus foi induzido pela injeção de STZ (65 mg/Kg, i.v.) 2 semanas antes. Os neutrófilos foram obtidos do lavado peritoneal 4 horas após injeção de solução de glicogênio de ostra tipo II (1\%). Grupos estudados: controles $(n=11)$ e diabéticos $(n=11)$, nas seguintes condições: tempo zero e estimulados ou não com PMA (20 nM). S6 foi utilizado como gene normalizador. 
Figura 13- Conteúdo das proteínas relacionadas à via da PERK da UPR.

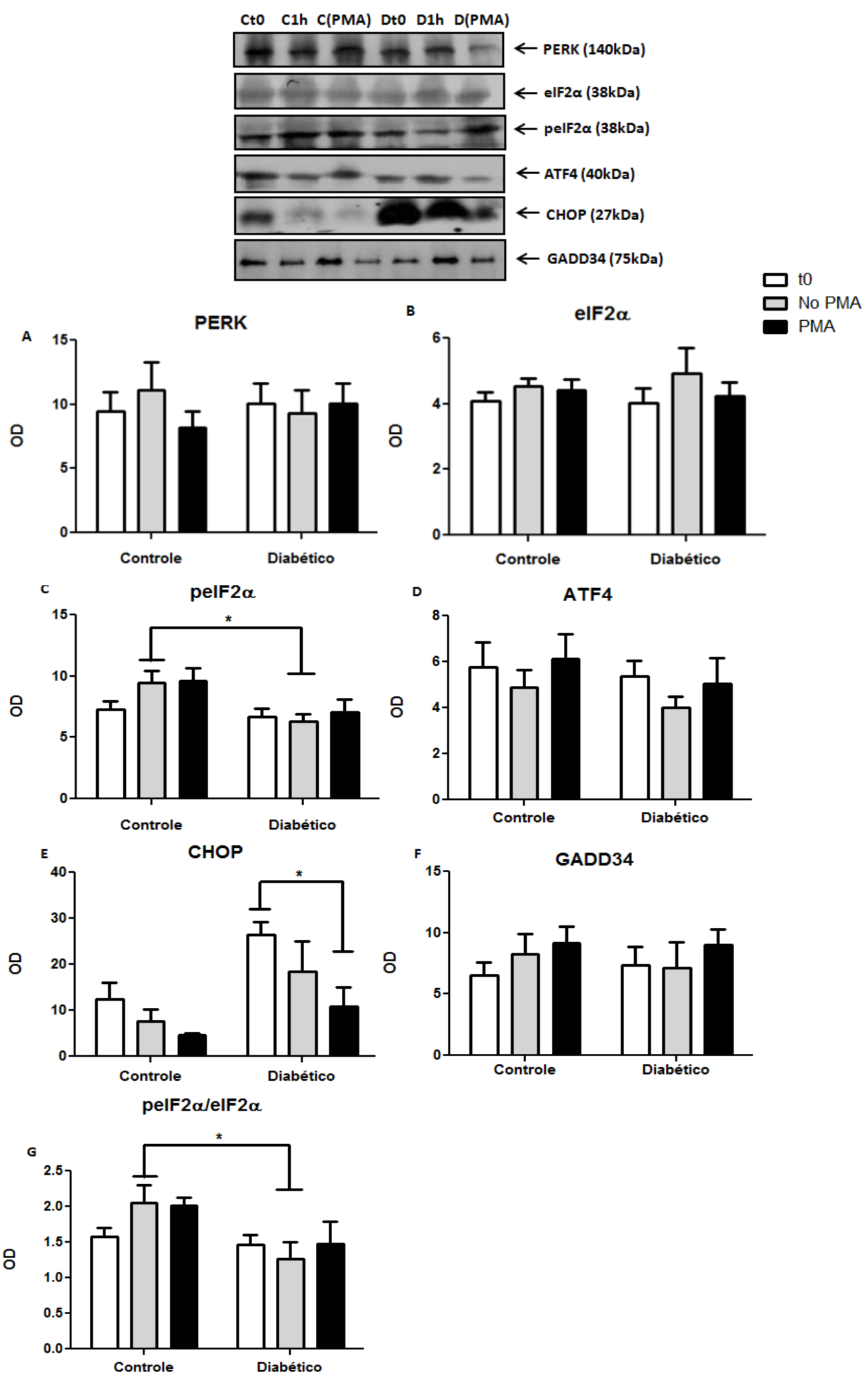

O diabetes mellitus foi induzido pela injeção de STZ (65 mg/Kg, i.v.) 2 semanas antes. Os neutrófilos foram obtidos do lavado peritoneal 4 horas após injeção de solução de glicogênio de ostra tipo II (1\%). Grupos estudados: controles $(n=6)$ e diabéticos $(n=6)$, nas seguintes condições: tempo zero (t0) e estimulados ou não com PMA (20 nM). Ct0: Controle t0. C1h: Conttrole No PMA 1h. C(PMA): Controle PMA 1h. Dt0: Diabético t0. D1h. Diabético No PMA 1h. D(PMA): Diabético PMA 1h. Bandas foram normalizadas pela membrana corada com ponceau. ${ }^{*} \mathrm{p}<0,05$. 
Figura 14- Splicing de XBP1 (A) e fosforilação da proteína JNK (B), eventos decorrentes da ativação de IRE1 $\alpha$.

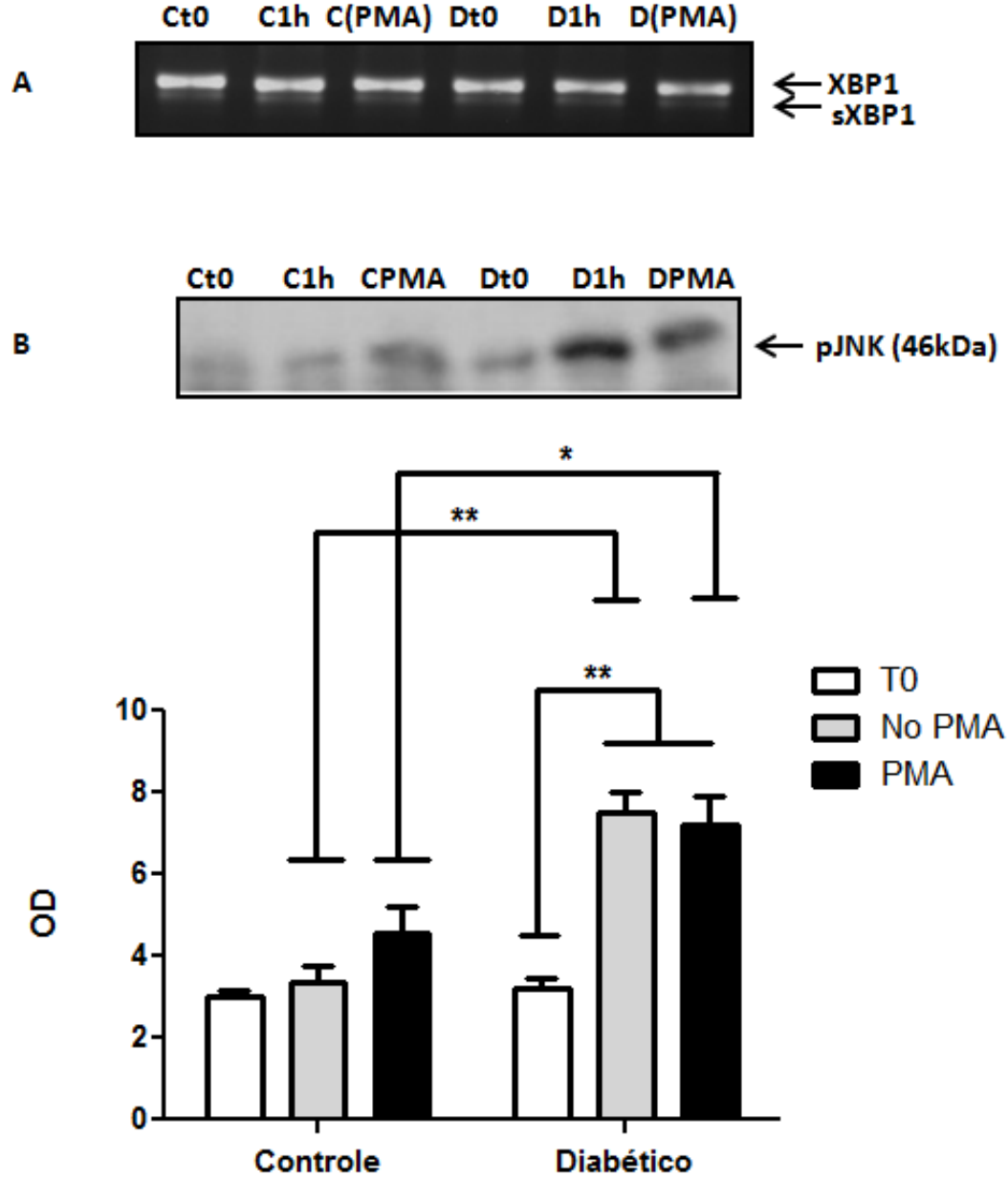

O diabetes mellitus foi induzido pela injeção de STZ (65 mg/Kg, i.v.) 2 semanas antes. Os neutrófilos foram obtidos do lavado peritoneal 4 horas após injeção de solução de glicogênio de ostra tipo II (1\%). Grupos estudados: controles $(n=2)$ e diabéticos $(n=2)$, nas seguintes condições: tempo zero e estimulados ou não com PMA (20 nM). Bandas do WB foram normalizadas pela membrana corada com ponceau. Ct0: Controle t0. C1h: Conttrole No PMA 1h. C(PMA): Controle PMA 1h. Dt0: Diabético t0. D1h. Diabético No PMA 1h. D(PMA): Diabético PMA 1h. Bandas foram normalizadas pela membrana corada com ponceau. ${ }^{*} \mathrm{p}<0,05 ; * * \mathrm{p}<0.01$. 
Figura 15- Conteúdo de ATF6.

Cto C1h CPMA Dto D1h DPMA
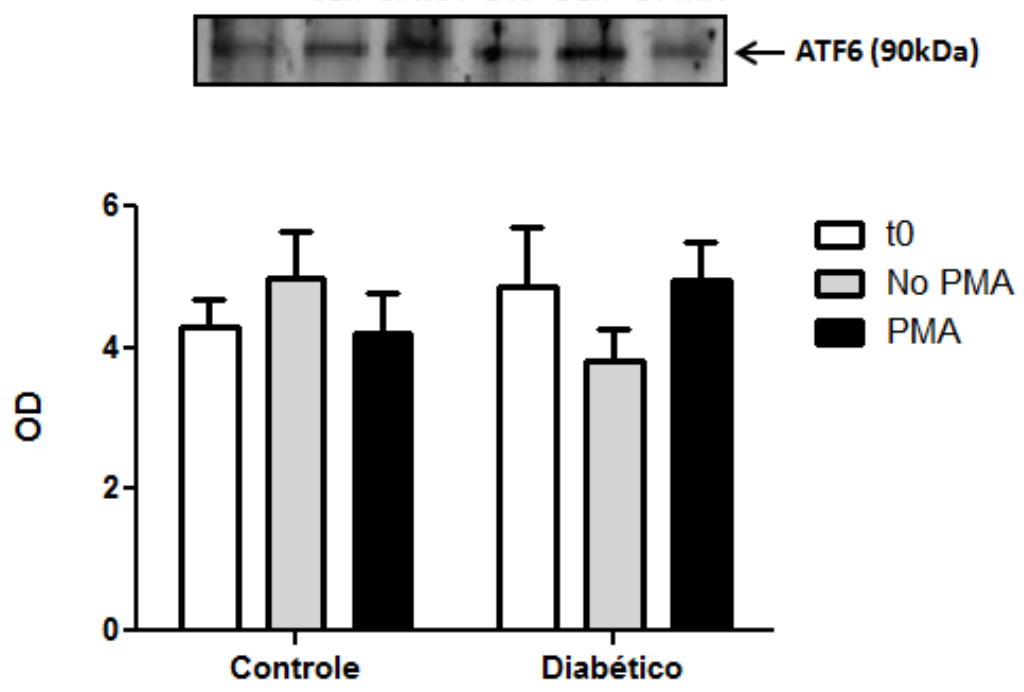

O diabetes mellitus foi induzido pela injeção de STZ (65 mg/Kg, i.v.) 2 semanas antes. Os neutrófilos foram obtidos do lavado peritoneal 4 horas após injeção de solução de glicogênio de ostra tipo II (1\%). Grupos estudados: controles $(n=6)$ e diabéticos $(n=6)$, nas seguintes condições: tempo zero e estimulados ou não com PMA (20 nM). Bandas foram normalizadas pela membrana corada com ponceau. Ct0: Controle t0. C1h: Conttrole No PMA 1h. C(PMA): Controle PMA 1h. Dt0: Diabético t0. D1h. Diabético No PMA 1h. D(PMA): Diabético PMA 1h. Bandas foram normalizadas pela membrana corada com ponceau.

Figura 16- Conteúdo de mitofusina 2

Cto C1h CPMA Dto D1h DPMA
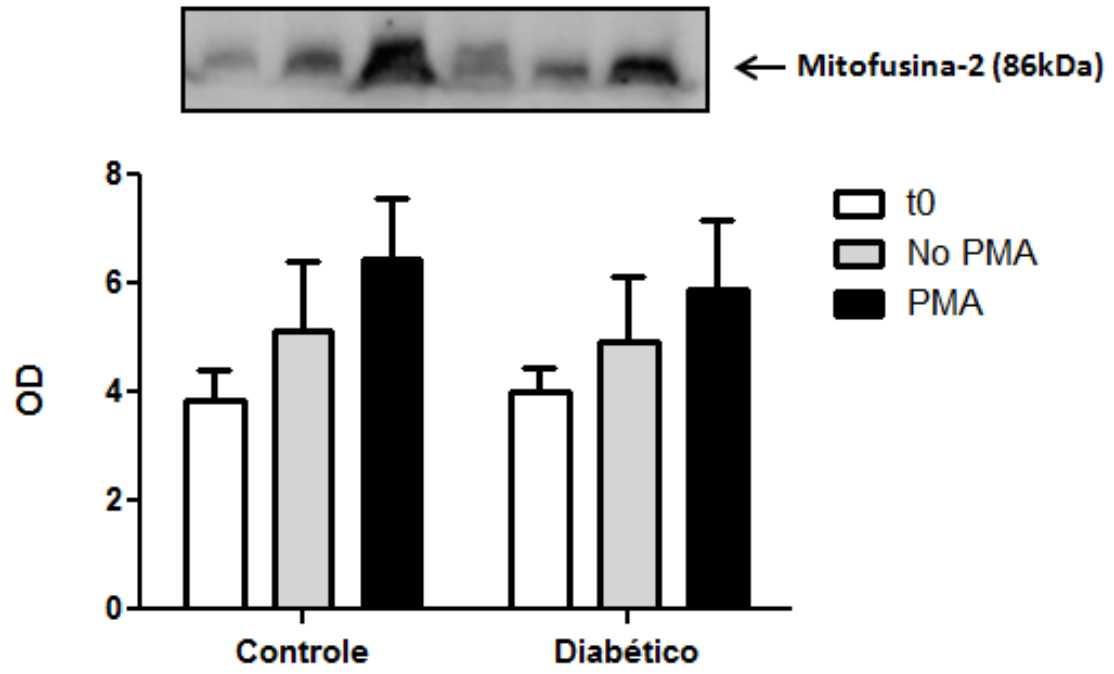

O diabetes mellitus foi induzido pela injeção de STZ (65 mg/Kg, i.v.) 2 semanas antes. Os neutrófilos foram obtidos do lavado peritoneal 4 horas após injeção de solução de glicogênio de ostra tipo II (1\%). Grupos estudados: controles $(n=6)$ e diabéticos $(n=6)$, nas seguintes condições: tempo zero e estimulados ou não com PMA $(20 \mathrm{nM})$. Bandas foram normalizadas pela membrana corada com ponceau. Ct0: Controle t0. C1h: Conttrole No PMA 1h. C(PMA): Controle PMA 1h. Dt0: Diabético t0. D1h. Diabético No PMA 1h. D(PMA): Diabético PMA 1h. Bandas foram normalizadas pela membrana corada com ponceau. 
Figura 17- A produção de EROs por neutrófilos através de quimiluminescência e a ação dos inibidores da NADPH oxidase

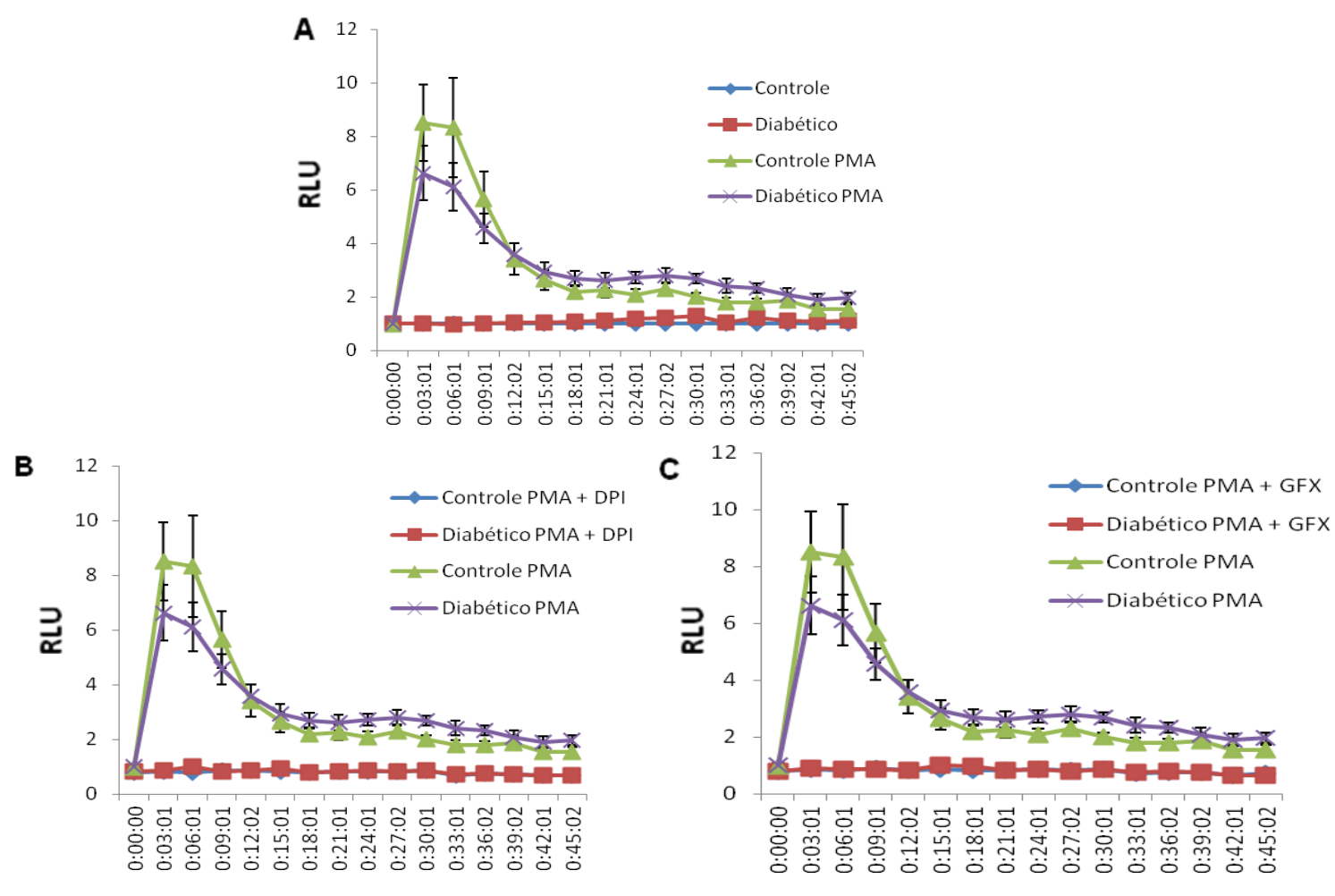

O diabetes mellitus foi induzido pela injeção de STZ (65 mg/Kg, i.v.) 2 semanas antes. Os neutrófilos foram obtidos do lavado peritoneal 4 horas após injeção de solução de glicogênio de ostra tipo II (1\%). Grupos estudados: controles $(n=12)$ e diabéticos $(n=12)$ estimulados ou não com PMA (20 nM) (A). A participação do complexo da NADPH oxidase e PKC na produção de EROs foi avaliada através da presença dos inibidores DPI $(10 \mu \mathrm{M})(\mathrm{B})$ e GFX $(0,2 \mu \mathrm{M})(\mathrm{C})$, respectivamente. Os valores representam a media das unidades relativas de luz (RLU) \pm e.p.m. 
Figura 18- Atividade das Caspases 3 em neutrófilos.

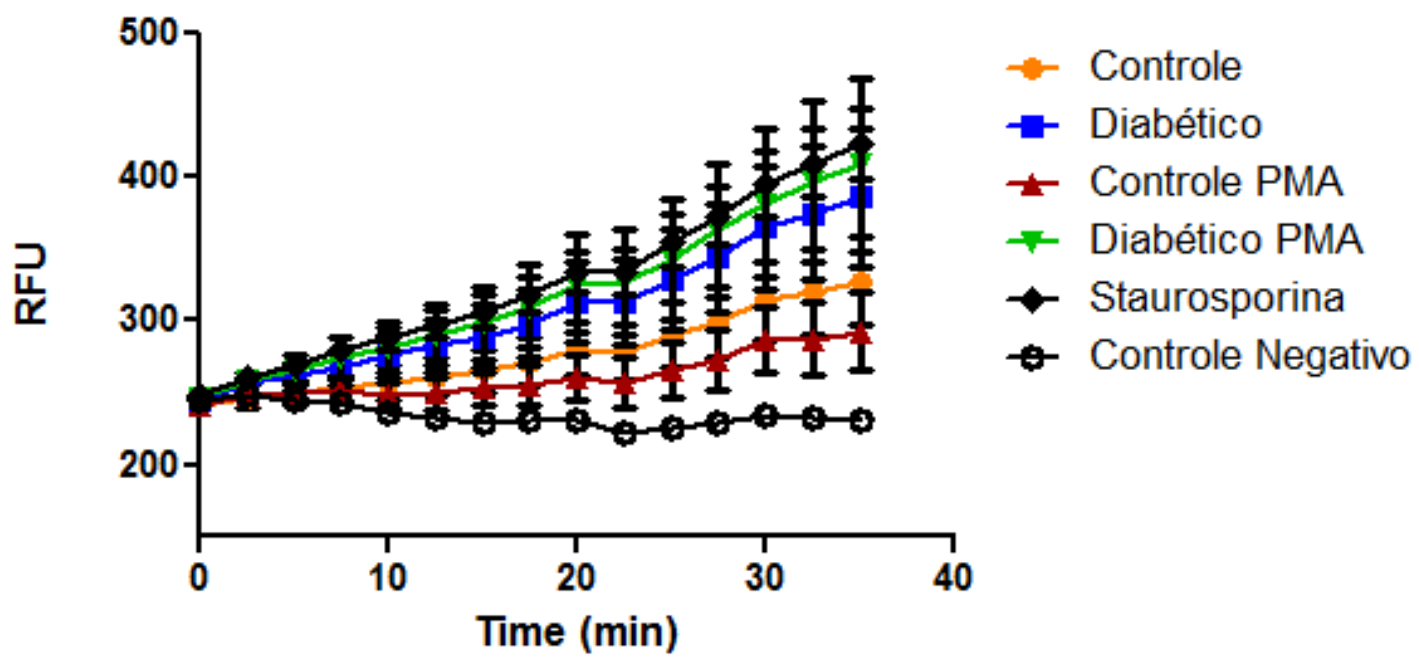

O diabetes mellitus foi induzido pela injeção de STZ (65 mg/Kg, i.v.) 2 semanas antes. Os neutrófilos foram obtidos do lavado peritoneal 4 horas após injeção de solução de glicogênio de ostra tipo II (1\%). Grupos estudados: controles e diabéticos $(n=6)$ estimulados ou não com PMA $(20 \mathrm{nM})$. A atividade das caspases foi avaliada através de espectrofluorimetria e os valores representam a media das fluorescências \pm e.p.m. 


\section{DISCUSSÃO}

Inicialmente pode-se inferir que o estado diabético dos animais, após a indução da droga diabetogênica estreptozotocina, foi caracterizado pela redução do ganho de peso corpóreo e aumento da glicemia no estado alimentado. A quantidade de neutrófilos que migrou para o peritôneo 4 horas após a administração do glicogênio de ostra diminuiu aproximadamente $70 \%$ em animais diabéticos. Estudos prévios demonstram que neutrófilos de animais diabéticos aderem menos ao endotélio, acarretando em menor número de células em local de inflamação (PEREIRA et al., 1987). Em 2006, Alba-Loureiro et al. demonstraram que neutrófilos de ratos diabéticos apresentam menor expressão de ICAM-1, uma proteína fundamental pra o processo de adesão leucocitária ao endotélio; o mesmo foi observado por Martins et al. (2006) em neutrófilos de animais diabéticos após o estímulo com LPS. Porém, essa redução do número de neutrófilos não implica nas análises realizadas em nosso estudo devido à normalização de todos os ensaios por número de células ou quantidade de proteína avaliada.

A primeira análise realizada para verificação da condição de estresse de RE foi a de morfologia através da microscopia de fluorescência. Em nosso estudo, verificou-se que neutrófilos de animais diabéticos tanto na condição basal quanto na condição estimulada (PMA $20 \mathrm{nM}$ ) apresentaram alterações da morfologia do RE quando comparados com células do grupo controle, indicando que a organela deve estar em condição de estresse. Segundo Kaufman (1999), em condições de estresse o RE aumenta de tamanho e perde sua morfologia característica com intuito de aumentar sua capacidade de dobramento de proteínas. Esse processo e as vias de sinalização em resposta a UPR vêm sendo bem definidos em células que secretam grandes quantidades de proteínas e/ou possuem alto metabolismo, como células $\beta$ pancreáticas, hepatócitos, osteoblastos, cardiomiócitos, entre outros (GASS; GIFFORD; BREWER, 2002; GASS et al., 2008; LAKSHMANAN et al., 2013; LIU et al., 2013). Nas células $\beta$ pancreáticas, por exemplo, a hiperglicemia é um grande indutor de estresse de RE. Essas células por apresentarem um transportador de glicose com alto Km, o GLUT 2 (THORENS et al., 2010), não limitam a entrada dessa molécula na célula, ou seja, não se saturam facilmente. Dessa maneira, quanto maior a concentração de glicose no meio extracelular, maior o transporte de glicose e maior a concentração dessa molécula no citosol. A glicose, por sua vez, estimula as células $\beta$ pancreáticas a produzirem insulina. Assim, o aumento nos níveis de glicose estimula a entrada de novas proteínas no RE para serem corretamente dobradas e exportadas para o Golgi, onde serão empacatodadas e preparadas 
para a secreção. Essa sobrecarga gera estresse no retículo endoplasmático das células $\beta$ pancreáticas e, caso o estímulo persista por muito tempo, a UPR ativa vias de morte celular (BACK et al., 2012; SANO; REED, 2013; TANG et al., 2012; WANG et al., 1998; ZINSZNER et al., 1998).

Estudos que relacionem polimorfonucleares (PMN), diabetes, estresse de retículo e morte celular são escassos na literatura. O primeiro estudo a demonstrar a ativação das vias da UPR em neutrófilos foi realizado por Binet et al. (2010), no qual verificou-se que o trióxido de arsênio (ATO) promove estresse de retículo em neutrófilos ativando, consequentemente, as vias de morte dependentes da organela. Nesse mesmo estudo, eles verificaram que o ATO induz a síntese de novo de proteínas, sendo que a maioria chaperonas, responsáveis por manter a homeostasia celular. Além disso, os pesquisadores inferem que a ativação do ER em PMN é geralmente um processo prolongado, acarretando em uma condição irreversível que leva a morte (BINET et al., 2010).

Em nosso estudo, verificou-se o aumento da expressão gênica da chaperona GRP78(BIP) nos neutrófilos do grupo controle sob estímulo de PMA. Nesse caso, assim como verificado por outros pesquisadores, o aumento da disponibilidade de chaperonas essenciais para o correto dobramento de proteínas seria o primeiro passo na ativação da UPR para resolução do estresse de retículo. Se o estresse for crônico e não houver resolução na primeira fase da UPR, outras vias que levam a morte são ativadas (SANO; REED, 2013; ZINSZNER et al., 1998; WANG et al., 1998). A não alteração na expressão gênica de GRP78 em neutrófilos dos animais diabéticos sugere que essas células estejam mais susceptíveis a indução do estresse como, por exemplo, na vigência de processo inflamatório, no qual aumenta a demanda de novas proteínas, dentre elas, citocinas e quimiocinas.

Verificamos também um aumento da expressão gênica de IRE1 $\alpha$ em neutrófilos de animais diabéticos, bem como um aumento na expressão desse gene nos neutrófilos dos grupos controle e diabético estimulados com PMA. A mesma situação aconteceu com a expressão gênica de CHOP. A expressão de CHOP pode ser aumentada pela ativação da via de PERK através de ATF4 ou pela via de ATF6, através da porção de 50 kDa dessa proteína proveniente da clivagem no complexo de Golgi (RON; WALTER, 2007). No entanto, não houve diferença significativa na expressão de PERK e ATF6, bem como na fosforilação de eIF2 $\alpha$, conteúdo de ATF4 e de ATF6, avaliados pela técnica de western blotting. Sano e Reed (2013) mostraram que IRE1 $\alpha$ pode fosforilar e ativar CHOP via p38 MAPK, mas até o momento não se constatou qualquer relação entre a ativação de IRE1 $\alpha$ e aumento da expressão gênica de CHOP. O aumento da expressão gênica de IRE1 $\alpha$ observado em nosso 
estudo não foi capaz de promover o aumento de sua atividade de processamento do mRNA XBP1. Porém, observou-se aumento no conteúdo da fosforilação de JNK em neutrófilos dos diabéticos estimulados ou não com PMA, sugerindo que a ativação de IRE1 $\alpha$, previamente observada, tenha promovido a fosforilação da quinase através da via TNF receptor-associated factor 2 (TRAF2) e ASK1. Sendo assim, esses dados reafirmam as duas vias independentes de IRE1 $\alpha$. Na primeira ocorre o splicing de XBP1 e o aumento na produção de chaperonas e proteínas da via de degradação ERAD e, a segunda, promove a fosforilação de JNK que é translocada para a membrana mitocondrial onde promove a ativação de Bim e inibição de Bcl-2 favorecendo abertura de poros e liberação de proteínas pró-apoptóticas, levando a morte celular (RON; WALTER, 2007; SANO; REED, 2013). Nossos dados indicam que, em neutrófilos de ratos diabéticos, a segunda via estaria ativada.

Por outro lado, apesar do aumento da expressão gênica de CHOP nos neutrófilos dos grupos controle e diabético, estimulados com PMA, observou-se a diminuição do conteúdo proteico nesses mesmos grupos. Esse dado, aparentemente conflitante, pode indicar o papel de degradação global de mRNAs do IRE1 $\alpha$, visando uma menor síntese proteica e menor entrada de novas proteínas no RE (RON; WALTER, 2007). Dessa maneira, mesmo que haja aumento da expressão gênica para a produção do mRNA responsável pela sítense de CHOP, esse mRNA seria degradado antes de ser traduzido, o que implicaria alto conteúdo de mRNA e baixo conteúdo proteico, como observado.

Outro ponto importante a ser abordado é a procedência do estímulo para o aumento da expressão gênica de CHOP. Como já visto, a via de PERK parece não ser ativada pelo PMA, principalmente por não observarmos alteração na fosforilação de eIF2 $\alpha$ e no conteúdo do fator de transcrição ATF4, responsável pela transcrição de CHOP, nos neutrófilos sob o estímulo. Porém, na ausência de PMA, os neutrófilos do grupo controle apresentam maior conteúdo de peIF $2 \alpha$ e razão peIF $2 \alpha /$ eIF $2 \alpha$ quando comparado com células do grupo diabético, fato que parece estar associado ao aumento da expressão de GRP78, porém não ao aumento de CHOP. O ATF6 parece também não participar dessa ativação, pois o menor conteúdo indicaria maior clivagem no golgi, o que também não foi observado. Mesmo assim, haveria necessidade de avaliação da porção clivada de ATF6, o p50ATF6, que devido a limitações metodológicas confiáveis não foi avaliada neste estudo. Apesar de Bruhat et al. (1999) verificarem que a deprivação de leucina resulta no aumento da expressão de CHOP, recentemente, Friedrich (2012) demonstrou que em pacientes com diabetes mellitus tipo 1 e tipo 2 apresentam a concentração de leucina aumentada, indicando que este também não seria o mecanismo de 
ativação de CHOP. Até o momento, não há na literatura a indicação de outros possíveis fatores que propiciariam o aumento da expressão de CHOP observada em nosso estudo.

O que podemos considerar é o elevado turnover dos neutrófilos, que poderia implicar as estas células apresentarem expressão de CHOP elevada, como se estivessem preparadas para o processo de morte. A regulação do conteúdo de CHOP ocorreria durante a ativação celular pela ação de degradação de mRNA do IRE1 $\alpha$, pois no decorrer de um processo inflamatório, por exemplo, os neutrófilos necessitam de sobrevida maior afim de combater o a gente invasor. A diminuição de CHOP promoveria a expressão gênica da proteína anti-apoptótica Bcl-2 que porpiciaria o aumento da sobrevida dessas células. Tabas e Ron (2011) observaram aumento de morte em cardiomiócitos quando induzidos ao estresse de retículo por apresentarem diminuição em $\mathrm{Bcl}-2$, porém em animais $\mathrm{CHOP}^{-/-}$a indução de estresse não promove alteração em $\mathrm{Bcl}-2$ e, consequentemente, os cardiomiócitos são protegidos do processo de morte. Bcl-2 medeia sua ação anti apoptótica por sequestrar proteínas da família BH3-only, como Bad, Bim, Noxa e Puma, que são necessárias para a permeabilização da mitocôndria mediada por Bax-Bak e, consequentemente, a apoptose (CHENG et al., 2001).

Em nosso modelo observou-se aumento, embora não significativo da razão Bax/Bcl-2 em neutrófilos de animais diabéticos indicando maior vulnerabilidade destas células ao processo de morte. A diminuição da expressão de Bcl-2 favorece a formação de poros na mitocôndria por Bax-Bak, liberação de proteínas mitocondriais e ativação de caspase 3 (UEDA et al., 2002; VAN RAAM et al., 2006). Esse processo pode ser independente (CHAUHAN et al., 1997) ou dependente da liberação de citocromo C da mitocôndria (LI et al., 1997; PAN et al., 1998) como consequência do estresse oxidativo, por exemplo (UEDA et al., 2002). A caspase 3 ativa proteínas responsáveis pela condensação da cromatina, fragmentação do DNA e pela formação de corpos apoptóticos (UEDA et al., 2002). A análise da atividade da caspase 3 em nosso estudo denota o aumento da atividade dessa proteína de $40 \%$ em neutrófilos do grupo diabético quando comparado com células do grupo controle, sob estímulo de PMA. Porém, apesar de não observarmos alteração com relação à geração de EROs por neutrófilos provenientes dos grupos e condições estudadas, verificamos que o PMA aumenta demasiadamente a produção de EROs pela NADPH oxidase, alterando o estado redox da célula e, consequentemente, de suas organelas. No caso dos neutrófilos provenientes de animais diabéticos, por apresentarem maior razão Bax/Bcl-2, a proteção contra o estresse oxidativo causado pelo estímulo é menor e, consequentemente, o processo de morte celular apresenta-se alterado. 
Ainda com relação à participação da mitocôndria e a possível interação com o RE no processo de morte celular, a região da MAM foi avaliada em nosso estudo através de suas proteínas reguladoras, sendo mitofusina-2, PACS2 e GRP75. Em neutrófilos de animais do grupo controle há um aumento significativo da expressão gênica de mitofusina 2 após estímulo com PMA, fato não observado em células provenientes de animais do grupo diabético o que implica na alteração na formação da MAM. Por outro lado, o conteúdo dessa proteína não alterou significativamente em neutrófilos de ambos os grupos após o estímulo com PMA, possivelmente devido ao tempo de exposição ao estímulo. Apesar da PACS2 ser necessária para a localização do Transiente Receptor Potential Protein 2 (TRPP2) no RE e promover o contato entre essa organela e a mitocôndria, impedindo a liberação de cálcio e importante para a translocação de Bid para a mitocôndria induzindo vias extrínsica e intrínsica da apoptose (ASLAN et al., 2009; SIMMEN et al., 2005), não houve alteração significativa na expressão gênica de PACS2 entre os grupos e condições estudados. Com relação a GRP75, neutrófilos de animais diabéticos apresentaram menor expressão gênica quando comparado às células provenientes do grupo controle, sob o estímulo de PMA. Neutrófilos de animais controle apresentam maior expressão desse gene, mesmo em condição não estimulado, o que indica que a interação entre RE e mitocôndria nestas células está ocorrendo. Estudos inferem que o aumento da expressão de GRP75 e de mitofusina 2 está associado a proteção da indução do processo de morte. No entanto, ainda não há consenso se esse efeito é devido a melhor interação entre RE e mitocôndria ou a influência no processo de apoptose per se (JAHANIASL et al., 2007; VOCOLI et al., 2007; XU et al., 2009).

A MAM é responsável pela troca de cálcio entre RE e mitocondria e a transferência de ATP da mitocôndria para o RE. Algumas regiões do retículo com alta atividade de dobramento de proteínas liberam cálcio para o citosol e, nos locais em que o íon se concentra, há a associação física das mitocôndrias através das proteínas GRP75, mitofusina 2 e PACS2, formando a MAM. O aumento de cálcio no interior da mitocôndria estimula a ATP sintase a produzir ATP, este é liberado na MAM e captado pelo RE, favorecendo o dobramento das proteínas corretamente e, consequentemente, impedindo o estresse de RE (SIMMEN et al., 2010). Considerando esse mecanismo de troca e que os neutrófilos do grupo diabético apresentam alteração da expressão gênica das proteínas responsáveis pela associação física entre RE e mitocôndria, o cálcio liberado na MAM não se limitaria somente nesta região e extravazaria para o citoplasma ativando proteases e fosfolipases que culminaria em processo de morte celular (CSORDÁS et al., 2010; SIMMEN et al., 2010). 
Em resumo, nosso estudo demonstrou que neutrófilos de ratos diabéticos quando estimulados com PMA apresentam maior suceptibilidade a morte devido à ativação de IRE1 $\alpha$ e, consequente, fosforilação de JNK; menor interação mitocôndria-RE na MAM e aumento da atividade de caspase 3. Essas alterações não seriam decorrentes da produção de EROs, devido o mesmo perfil encontrado em neutrófilos dos grupos estudados. Além disso, neutrófilos provenientes de animais controle parecem estar protegidos do estresse de RE por apresentar maior expressão de GRP78 e das proteínas da MAM. Os resultados obtidos podem corroborar para melhor compreensão de alterações funcionais dos neutrófilos observadas em pacientes diabéticos, como diminuição da expressão de proteínas de adesão, alterações no processo de fagocitose e resolução do processo inflamatório (GEERLINGS et al., 1999). Se a relação mitocôndria-RE, participação destas organelas no processo de morte e o estresse de RE em neutrófilos forem elucidados na vigência do diabetes mellitus, será possível progredir na compreensão da dinâmica do processo inflamatório, desenvolvimento de novas terapias farmacológicas e, consequentemente, na melhora da qualidade de vida de grande parte da população mundial acometida por esta síndrome. 


\section{REFERENCIAS}

ABO, A.; WEBB, M. R.; GROGAN, A.; SEGAL, A.W. Activation of NADPH oxidase involves the dissociation of p21 rac from its inhibitory GDP/GTP exchange protein (rhoGDI) followed by its translocation to the plasma membrane. Biochem. J., v. 3, p. 585-591, 1994.

AMERICAN DIABETES ASSOCIATION (ADA). Report of the expert committee on the diagnosis and classification of diabetes mellitus. Diab. Care., v. 20, p. 1183-1197, 1997.

AGNER, K. Biological effects of hypochlorous acid formed by "MPO"-peroxidation in the presence of chloride ions. In: Akeson, A. e Ehrenberg, A. editors. Structure and Function of Oxidation Reduction Enzymes. New York: Pergamon; vol.18, p. 329-335, 1972.

ALBA-LOUREIRO, T. C.; HIRABARA, S. M.; MENDONÇA; J. R., CURI, R.; PITHONCURI T.C. Diabetes causes marked changes in function and metabolism of rat neutrophils. J. Endocrinol., v. 188, p. 295-303, 2006 b.

ALBA-LOUREIRO, T. C.; MARTINS, E. F.; LANDGRAF R. G.; JANCAR S.; CURI R.; SANNOMIYA P. Role of insulin on PGE2 generation during LPS-induced lung inflammation in rats. Life Sci., v. 78, p. 578-585, 2006 a.

ALDRIDGE, G. M.; PODREBARAC D. M.; GREENOUGH W. T.; WEILER I. J. The use of total protein stains as loading controls:

an alternative to high-abundance singleprotein controls insemi-quantitative immunoblotting. J. Neurosci. Methods, v. 172, n. 2, p. 250-254, 2008

ANDERSEN, B.; GOLDSMITH, G. H.; SPAGNUOLO, P. J. Neutrophil adhesive dysfunction in diabetes mellitus: the role of cellular and plasma factors. J. Lab. Clin. Med., v. 111 , p. $275-285,1988$.

ANDERSSON, M.; SJOSTRAND, J.; PETERSEN, A.; HONARVAR, A. K.; KARLSSON, J.O.; Caspase and proteasome activity during staurosporin-induced apoptosis in lens epithelial cells. Invest. Ophthalmol. Vis. Sci., v. 41, n. 9, p. 2623-2632, 2000.

ANJOS-VALLOTA, E.; OLIVEIRA, M. A.; BRITTO, L. R. G.; FORTES, Z. B.; SANNOMIYA, P. Downregulation of ICAM-1 (CD54) by plasma proteins in diabetes mellitus. Med. Inflamm., v. 8, p. 92-96, 1999.

APPENZELLER-HERZOG, C.; RIEMER, J.; ZITO, E.; CHIN, K. T.; RON, D.; SPIESS, M.; ELLGAARD, L. Disulphide production by Ero1 $\alpha-$ PDI relay is rapid and effectively regulated. EMBO J., v. 29, p. 3318-3329, 2010.

ASHKENAZI, A.; DIXIT, V. M. Death receptors: signaling and modulation. Science, v. 281, p. 1305-1308, 1998.

\footnotetext{
* De acordo com:

ASSOCIAÇÃO BRASILEIRA DE NORMAS TÉCNICAS. NBR 6023: informação e documentação: referências: elaboração. Rio de Janeiro, 2002.
} 
ASLAN, J. E.; YOU, H.; WILLIAMSON, D. M.; ENDIG, J.; YOUKER, R. T.; THOMAS, L.; SHU, H.; DU, Y.; MILEWSKI, R. L.; BRUSH, M. H.; POSSEMATO, A ; SPROTT, K.; FU, H.; GREIS, K. D.; RUNCKEL, D. N.; VOGEL, A. Thomas G. Akt and 14-3-3 control a PACS-2 homeostatic switch that integrates membrane traffic with TRAIL-induced apoptosis. Mol. Cell, v. 34, p.497-509, 2009.

ATKINSON, M.; MACLAREN, N. The pathogenesis of insulin-dependent diabetes mellitus. N. Engl. J. Med., v. 331, p. 1428-1436, 1994.

BABIOR, B. M. The respiratory burst oxidase and the molecular basis of chronic granulomatous disease. Am. J. Hematol., v. 37, n. 4, p. 263-266, 1991.

BABIOR, B. M.; CURNUTTE, J. T.; KIPNES, R. S. biological defense mechanisms. Evidence for the participation of superoxide in bacterial killing by xanthine oxidase. J. Lab. Clin. Med., v. 85, p. 235-244, 1975.

BABIOR, B. M.; KIPNES, R. S.; CURNUTTE, J. T. Biological defense mechanisms: the production by leukocytes of superoxide, a potential bactericidal agent. J. Clin. Invest., v. 52, p. $741-744,1973$.

BACK, S. H.; KAUFMAN, R. J. Endoplasmic reticulum stress and type 2 diabetes. Annu Rev Biochem 81: 767-793, 2012.

BEILKE, M. A.; COLLINS-LECH, C.; SOHNLE, P. G. Candidacidal activity of the neutrophil myeloperoxidase system can be protected from excess hydrogen peroxidase by the presence of ammonium ion. Blood, v. 73, n. 4, p. 1045-1049, 1989.

BERNALES, S.; PAPA, F. R.; WALTER, P. Intracellular signaling by the unfolded protein response. Annu. Rev. Cell. Dev. Biol., v. 22, p. 487-508, 2006.

BERTON, G. Desgranulation. In: Gallin, j.i. e Snyderman, R. Editors. Inflammation: Basic principles and clinical correlates. 3rd ed. Philadelphia: Lippincott Williams and Wilkins; vol 1., p. 70-73, 1999.

BINET, F.; CHIASSON, S.; GIRARD, D. Evidence that endoplasmic reticulum (ER) stress and caspase-4 activation occur in human neutrophils. Biochemical and Biophysical Research Communications, v. 391, p.18-23, 2010.

BOATRIGHT, K. M.; SALVESEN, G. S. Mechanisms of caspase activation. Curr. Opin. Cell Biol., v. 15, p. 725-731, 2003.

BOICHOT, E.; SANNOMIYA, P.; ESCOFIER, N.; GERMAIN, N.; FORTES, Z. B.; LAGENTE, V. Endotoxin-induced acute lung injury in rats. Role of insulin. Pulm. Pharmacol. Ther., v. 12, n. 5, 285-290, 1999.

BONADONNA, R. C.; DE FRONZO, R. A. Glucose metabolism in obesity and type 2 diabetes. Diabete Metab., v. 17, p. 112-135, 1991.

BRUHAT, A.; JOUSSE， C.; FAFOURNOUX， P. Amino acid limitation regulates gene expression. Proc. Nutr. Soc., v. 58, n. 3, p. 625-632, 1999. 
CASSATELlA, M. A. Neutrophil-derived proteins: selling cytokines by the pound. Adv Immunol., v. 73, p. 369-509, 1999.

CHAUHAN, D.; PANDEY, P.; OGATA, A.; TEOH, G.; KRETT, N.; HALGREN, R.; ROSEN, S.; KUFE, D.; KHARBANDA, S.; ANDERSON, K. Cytochrome c-dependent and independent induction of apoptosis in multiple myeloma cells. J. Biol. Chem., v. 272, p. 29995-29997, 1997.

CHEN, H.; DETMER, S. A.; EWALD A. J.; GRIFFIN, E. E.; FRASER, S. E.; CHAN, D. C. Mitofusins Mfn1 and Mfn2 coordinately regulate mitochondrial fusion and are essential for embryonic development. J. Cell Biol., v. 160, p. 189-200, 2003.

CHENG, E. H.; WEI M. C.; WEILER, S.; FLAVELL, R. A.; MAK, T. W.; LINDSTEN T.; KORSMEYER, S. J. BCL-2, BCL-X(L) sequester BH3 domain-only molecules preventing BAX- and BAK-mediated mitochondrial apoptosis. Mol. Cell., v. 8, p. 705-711, 2001.

CHOMCZYNSKI, P.; SACCHI, N. Single-step method of RNA isolation by acid guanidinium thiocyanate-phenol-chloroform extration. Anal. Biochem., v. 162, p. 156-159, 1987.

CHOMCZYNSKI, P. A reagent for the single-step simultaneous isolation of RNA, DNA and proteins from cell and tissue samples. Biotechniques, v. 15, n. 3, p. 532-534, 1993.

COURTEN, M.; HODGE, A. M.; ZIMMET, P. Epidemiology of diabetes: lessons for the endocrinologist. Endocrinology, v. 8, p. 62-70, 1998.

CSORDÁS, G.; RENKEN, C.; VÁRNAI, P.; WALTER, L.; WEAVER, D.; BUTTLE K. F.; BALLA, T.; MANNELLA, C. A.; HAJNÓCZKY, G.. Structural and functional features and significance of the physical linkage between ER and mitochondria. J. Cell Biol., v. 174, p. 915-221, 2006.

DACHEUX, D.; TOUSSAINT, B.; RICHARD, M.; BROCHIER, G.; CROIZE, J.; ATTREE, I. Pseudomonas aeruginosa cystic fibrosis isolates induced rapid, type III secretion-dependent, but ExoU-independent, oncosis on macrophages and polymorphonuclear neutrophils. Infect Immun., v. 68, p. 2916-2924, 2000.

DANA, R.; LET, T. L.; MALECH, H. L.; LEVY, R. Essential requirement of cytosolic phospholipase A2 for activation of the phagocyte NADPH oxidase. J. Biol. Chem., v. 273, p. 441-445, 1998.

DELAMAIRE, M.; MAUGENDRE, D.; MORENO, M.; LE GOFF, MC.; ALLANNIC, H.; GENETET, B. Impaired leucocyte functions in diabetic patients. Diabet Med., v. 14, p. 2934, 1997.

DIEBOLD, B. A.; BOKOCH, G. M. Molecular basis for Rac2 regulation of phagocyte NADPH oxidase. Nat. Immunol., v. 2, n. 3, p. 211-215, 2001. 
DIEKMANN, D.; ABO, A.; JONSTON, C.; SEGAL, A.W.; HALL, A. Interaction of Rac with p67phox and regulation of phagocytic NADPH oxidase activity. Science, v. 265, n. 5171, p. 531-533, 1994.

DINAUER, M. C.; ORKIN, S. H. Chronic granulomatous disease. Annu. Rev. Med., v. 43, p. 117-124, 1992.

DJALDETTI, M.; SALMAN, H.; BERGMAN, M.; DJADETTI, R.; BESSLER, H. phagocytosis - the might weapon of the silent warriors. Microsc. Res. Tech., v. 57, n. 6, p. 421-431, 2002.

DOMIGAN, N. M.; CHARLTON, T. S.; DUNCAN, M. W.; WINTERBOURN, C. C.; KETTKE, A. J. Chlorination of tyrosyl residues in peptides by myeloperoxidase and human neutrophils. J. Biol. Chem., v. 270, n. 28, p. 16542-16548, 1995.

EMORY UNIVERSITY. NADPH oxidase. Disponível em: <http://www.pathology.emory.edu/Lambeth/nadphpage.html>. Acesso em: 08 Ago. 2013.

FANTONE, J. C.; WARD, P.A. Role of oxygen-derived free radicals and metabolites in leukocyte-dependent inflammatory reactions. Am. J. Pathol., v. 107, p. 397-418, 1982.

FENTON, H. J. H. Oxidation of tartaric acid in the presence of iron. J. Chem. Soc., v. 65, p. 899-910, 1894.

FERNANDES-ALNEMRI, T.; WU, J.; YU, J. W.; DATTA, P.; MILLER, B.; JANKOWSKI, W. The pyroptosome: a supramolecular assembly of ASC dimers mediating inXammatory cell death via caspase-1 activation. Cell Death Div., v. 14, p. 1590-1604, 2007.

FINK, S. L.; COOKSON, B. T. Caspase-1-dependent pore formation during pyroptosis leads to osmotic lysis of infected host macrophages. Cell Microbiol., v 8, p. 1812-1825, 2006.

FORTES, Z. B.; FARSKY, S. P.; OLIVEIRA, M. A.; GARCIA-LEME, J. Direct vital microscopic study of defective leukocyte-endothelial interaction in diabetes mellitus. Diabetes, v. 40, p. 1267-1273, 1991.

FOSSATI, G.; MOULDING, D. A.; SPILLER, D. G.; MOOTS, R. J.; WHITE, M. R. H.; EDWARDS, S. W. The Mitochondrial Network of Human Neutrophils: Role in Chemotaxis, Phagocytosis, Respiratory Burst Activation, and Commitment to Apoptosis. J. Immunol., v. 170, p. 1964-1972, 2003.

FRAKER, D. L.; MERINO, M. J.; NORTON, J. A. Reversal of the toxic effects of cachectin by concurrent insulin administration. Am. J. Physiol., v. 256, p. 725-731, 1989.

FRANC, N. C.; WHITE, K.; EZEKOWITZ, R. A. Phagocytosis and development back to the future. Curr. Opin. Immunol., v. 11, n. 1, p. 47-52, 1999.

FRIEDRICH, N. Metabolomics in diabetes research. J. Endocrinol., v. 215, n. 1, p. 29-42, 2012. 
FUCHS, T. A.; ABED, U.; GOOSMANN, C.; HURWITZ, R.; SCHULZE, I.; WAHN, V. Novel cell death program leads to neutrophil extracellular traps. J. Cell Biol., v. 176, p. 231$241,2007$.

GABIG, T. G.; CREAN, C. D.; MANTEL, P. L.; ROSLI, R. Function of wild-type or mutant Rac2 and Rapla GTPases in differentiated HL-60 cell NADPH oxidase activation. Blood., v. 85, p. 804-811, 1995.

GALLACHER, S. J.; THOMSON, G.; FRASER, W. D.; FISHER, B. M.; GEMMELL, C. G.; MACCUISH A. C. Neutrophil bactericidal function in diabetes mellitus: evidence for association with blood glucose control. Diabet Med., v. 12, p. 916-920, 1995.

GASS, J. N.; GIFFORD, N. M.; BREWER, J. W.; Activation of an unfolded protein response during differentiation of antibody-secreting B cells. J. Biol. Chem., v. 277, p. 49047-49054, 2002.

GASS, J. N.; JIANG, H. Y., WEK, R. C., BREWER, J. W. The unfolded protein response of Blymphocytes: PERK-independent development of antibody-secreting cells. Mol. Immunol., v. 45, p. 1035-1043, 2008.

GEERLINGS, S. E.; HOEPELMAN, A. I. Immune dysfunction in patients with diabetes mellitus (DM). FEMS Immunol. Med. Microbiol., v. 26, p. 259-265, 1999.

GILES, K. M.; HART, S. P.; HASLLETT, C.; ROSSI, A. G.; DRANSFIELD, I. An appetite for apoptotic cells? Controversies and challenges. Br. J. Haematol., v. 109, n. 1, 1-12, 2000.

GREEN, D. R. Apoptotic pathways: the roads to ruin. Cell, v. 94, n. 6, p. 695-698, 1998.

GRISHAM, M. B.; JEFFERSON, M. M.; MELTON, D. F.; THOMAS, E. L. Chlorination of endogenous amines by isolated neutrophils. Ammonia-dependent bactericidal, cytotoxic and cytolytic activities of the chloramines. J. Biol. Chem., v. 259, n. 16, p. 10404-10416, 1984.

HABER, F.; WEISS, J. The catalytic decomposition of hydrogen peroxide by iron salts. Proc. R. Soc. Lond. A., v. 147, p. 332-351, 1934.

HAJNOCZKY, G. et al. Calcium signiling and apoptosis. Biochem, Biophys. Res. Commun., v. 304, p. 445-454, 2003.

HAN, C.; FREEMAN, J. L.; LEE, T.; MOTALEBI, S. A.; LAMBETH, J. D. Regulation of the neutrophil respiratory burst oxidase. Identification of an activation domain in p67(phox). J. Biol. Chem., v. 273, n. 27, p. 16663-16668, 1998.

HARDING, H. P.; NOVOA, I.; ZHANG, Y.; ZENG, H.; WEK, R.; SCHAPIRA, M.; RON, D. Regulated translation initiation controls stress-induced gene expression in mammalian cells. Mol Cell. v. 6, n. 5, p. 1099-108, 2000a.

HARDING, H. P.; ZHANG, Y.; BERTOLOTTI, A.; ZENG, H.; RON, D. Perk is essential for translational regulation and cell survival during the unfolded protein response. Mol. Cell, v.5, n. 5, p. 897-904, 2000b. 
HARDING, H. P.; ZHANG, Y.; RON, D. Protein translation and folding are coupled by an endoplasmatic-reticulum-resident kinase. Nature, v. 397, p. 271-274, 1999.

HARRISON, J. E.; SHULTZ, J. Studies on the chlorinating activity of myeloperoxidase. J. Biol. Chem., v. 251, n. 5, p. 1371-1375, 1976.

HAYASHI, T.; SU, T. P. Sigma-1 Receptor chaperones at the ER-mitochondrion interface regulate Ca2+ signaling and cell survival. Cell., v. 131, p. 596-610, 2007.

HETZ, C.; GLIMCHER, L. The daily job of night killers: althernative roles of the BCL-2 family in organelle physiology. Trends Cell Biol., v. 18, p. 38-44, 2008.

HEYWORTH, P. G.; BOHL, B. P.; BOKOCH, G. M.; CURNUTTE, J. T. Rac translocates independently of the neutrophil NADPH oxidase components p47phox and p67phox. Evidence for its interaction with flavocytochrome b558. J. Biol. Chem., v. 269, n. 49, p. 30749-30752, 1994.

HIGO, T.; HATTORI, M.; NAKAMURA, T.; NATSUME, T.; MICHIKAWA, T.; MIKOSHIBA, K. Subtype-specific and ER luminal environment-dependent regulation of inositol 1,4,5-triphosphate receptor type 1 by ERp44. Cell., v. 120, p. 85-98, 2005.

HIGUCHI, R.; DOLLINGER, G.; WALSH, P.S.; GRIFFITH, R. Simultaneous amplification and detection of specific DNA sequences. Biotechnol (New York), v. 10; p. 413-417, 1992.

IMLAY, J. A.; LINN, S. Bimodal pattern of killing of DNA-repair-defective or anoxically grown Escherichia coli by hydrogen peroxide. J. Bacteriol., v. 166, n. 2, p. 519-527, 1986.

IYER, G. Y. N.; ISLAM, M. F.; QUASTEL, J. H. Biochemical aspects of pathogenesis. Nature., v. 192, p. 535-541, 1961.

JAHANI-ASL, A.; CHEUNG, E. C.; NEUSPIEL, M.; MACLAURIN, J. G.; FORTIN, A.; PARK, D. S.; MCBRIDE, H. M.; SLACK, R. S. Mitofusin 2 protects cerebellar granule neurons against injury-induced cell death. J. Biol. Chem., v. 282, p. 23788-23798, 2007.

KANNEGANTI, T. D.; LAMKAN, W. M.; NUNEZ, G. Intracellular NOD-like receptors in host defense and disease. Immunity., v. 27, p. 549-559, 2007.

KAPLAN, M. J. Neutrophils in the pathogenesis and manifestations of SLE. Nat Rev Rheumatol., v. 7, n. 12, p. 691-699, 2011.

KAUFMAN,R.J.Stress signaling fromthe lumen ofthe endoplasmic reticulum: coordination of gene transcriptional andtranslational controls. Genes Dev., v. 13, n. 10, p. 1211-33, 1999.

KAWAKAMI, N.; KITA, K.; HAYAKAWA, T.; YAMAGUCHI, T.; FUJIMOTO, S. Phorbor myristate acetate induces NADPH oxidase activity of cytochalasin B-primed neutrophils through the protein kinase C-independent pathway. Biol. Pharm. Bull., v. 23, n. 9, p. 1100-1104, 2000.

KERR, J. F. R.; WYLLIE, A. H.; CURRIE, A. R. Apoptosis: a basic biological phenomenon with wide-ranging implications in tissue kinetics. Br. J. Cancer., v. 26, p. 239-571, 1972. 
KETTLE, A. J.; WINTERBOURN, C. C. Myeloperoxidase: a key regulator of neutrophil oxidant production. Redox Rep., v. 3, n. 3, 1997.

KIRWAN, J. P.; KRISHNAN, R. K.; WEAVER, J. A.; DEL AGUILA, L. F.; EVANS W. J. Human aging is associated with altered TNF-alpha production during hyperglycemia and hyperinsulinemia. Am. J. Physiol. Endocrinol. Metab., v. 281, p. 1137-1143, 2001.

KLEBANOFF, S. J. Myeloperoxidase-halide-hydrogen peroxide anti-bacterial system. J. Bacteriol., v. 95, n. 6, p. 2131-2138, 1968.

KLEBANOFF, S. J. Phagocytic cells: products of oxygen metabolism. In: GALLIN, J. I.; GOLDSTEIN, I. M.; SNYDERMAN, R. (Ed.). Inflammation: basic principles and clinical correlates. New York: Raven, 1992. p. 451-460.

KLEBANOFF, S. J. Role of the superoxide anion in the myeloperoxidase-mediated antimicrobial system. J. Biol. Chem., v. 249, p. 3724, 1974.

KLIONSKY, D. J.; ABELIOVICH, H.; AGOSTINIS, P.; AGRAWAL, D. K.; ALIEV, G.; ASKEW, D. S. Guidelines for the use and interpretation of assays for monitoring autophagy in higher eukaryotes. Autophagy, v. 4, p. 151-175, 2008.

KNAUS, U. G.; HEYWORTH, P. G.; EVANS, T.; CURNUTTE, J. T.; BOKOCH, G. M. Regulation of phagocyte oxygen radical production by the GTP-binding protein Rac-2. Science, v. 254, p. 1512-1515, 1991.

KNEPPER-NICOLAI, B.; SAVILL, J.; BROWN, S. B. Constitutive apoptosis in human neutrophils requires synergy between calpains and the proteasome downstream of caspases. $\mathbf{J}$. Biol. Chem., v. 273, n. 46, p. 30530-30536, 1998.

KOSHIBA, T.; DETMER, S. A.; KAISER, J. T.; CHEN, H.; MCCAFFERY, J. M.; CHAN, D. C. Structural basis of mitochondrial tethering by mitofusin complexes, Science., v. 305, p. 858-862, 2004.

KOTTGEN, M.; BENZING, T.; SIMMEN, T.; TAUBER, R.; BUCHHOLZ, B.; FELICIANGELI, S.; HUBER, T. B.; SCHERMER, B.; KRAMER-ZUCKER A.; HOPKER K.; SIMMEN K. C.; TSCHUCKE C. C.; SANDFORD R.; KIM E.; THOMAS G.; WALZ G. Trafficking of TRPP2 by PACS proteins represents a novel mechanism of ion channel regulation. Embo J., v. 24, p. 705-716, 2005.

KUKREJA, A.; MACLAREN, N.K. Autoimmunity and Diabetes. J. Clin. Endocrinol. Metab., v. 84, n. 12, p. 4371-4378, 1999.

LAKSHMANAN, A. P.; HARIMA, M.; SUZUKI, K.; SOETIKNO, V.; NAGATA, M,; NAKAMURA, T.; TAKAHASHI, T.; SONE, H.; KAWACHI, H.; WATANABE, K. The hyperglycemia stimulated myocardial endoplasmic reticulum (ER) stress contributes to diabetic cardiomyopathy in the transgenic non-obese type 2 diabetic rats: a differential role of unfolded protein response (UPR) signaling proteins. Int. J. Biochem. Cell Biol., v. 45, n. 2, p. 438-447, 2013. 
LAURINDO, F.; PESCATORE, A.; FERNANDES, D. Protein disulfide isomerase in redox cell signaling and homeostasis. Free Radical Biology e Medicine, v. 52, p. 1954-1969, 2012.

LEVIN, S.; BUCCI, T. J.; COHEN, S. M.; FIX, A. S.; HARDISTY, J. F.; LEGRAND, E. K. The nomenclature of cell death: recommendations of an ad hoc committee of the society of toxicologic pathologists. Toxicol. Pathol., v. 27, p. 490, 1999.

LI, P.; NIJHAWAN, D.; BUDIHARDJO, I.; SRINIVASULA, S.; ALNEMRI, E. S.; WANG, $\mathrm{X}$. Cytochrome $\mathrm{c}$ and dATP-dependent formation of Apaf-1/caspase-9 complex initiates an apoptotic protease cascade. Cell, v. 91, p. 479-489, 1997.

LIANG, X. H.; JACKSON, S.; SEAMAN, M.; BROWN, K.; KEMPKES, B.; HIBSHOOSH, $\mathrm{H}$. Induction of autophagy and inhibition of tumorigenesis by beclin 1. Nature, v. 402, p. 672-676, 1999.

LIDA, K. T.; SHIMANO, H.; KAWAKAMI, Y. SONE, H. TOYOSHIMA, H. SUZUKI, S. Insulin up-regulates tumor necrosis factor-alpha production in macrophages through an extracellular-regulated kinase-dependent pathway. J. Biol. Chem., v. 276, p. 32531-32537, 2001.

LISBONA, F.; ROJAS-RIVEIRA, D.; THIELEN, P.; ZAMORANO, S.; TODD, D.; MARTINON, F.; GLAVIC, A.; KRESS, C.; LIN, J. H.; WALTER, P.; REED, J. C.; GLIMCHER, L. H.; HETZ, C. BAX inhibitor-1 is a negative regulator of the ER stress sensor IRE1alpha. Mol Cell., v. 33, p. 679-425, 2009.

LIU, W.; ZHU, X.; WANG, Q.; WANG, L. Hyperglycemia induces endoplasmic reticulum stress-dependent CHOP expression in osteoblasts. Exp Ther Med., v. 5, n. 5, p. 1289-1292, 2013.

LIU, X.; ZWEIER, J. L. A real-time electrochemical technique for measurement of cellular hydrogen peroxide generation and consumption-evaluation in human polymorphonuclear leukocytes. Free Rad. Biol. Med., v. 31, n. 7, v. 894-901, 2001.

LIVAK, K. J.; SCHMITTGEN, T. D. Analysis of relative gene expression data using realtime quantitative PCR and the 2(-Delta Delta C(T)) Method. Methods, v. 25, n. 4, p. 402408, 2001.

LU, P. D.; HARDING, H. P.; RON, D. Translation reinitiation at alternative open reading frames regulates gene expression in an integrated stress response. J. Cell Biol., v. 167, p. 27 33, 2004.

LYMAR, S. V.; HURST, J. K. Role of compartmentation in promoting toxicity of leukocytegenerated strong oxidants. Chem. Res. Toxicol., v. 8, n. 6, p. 833-840, 1995.

MA, Y.; HENDERSHOT, L. M, The unfolding tale of the unfolded protein response. Cell., v. 107, n. 7, p. 827-830, 2001.

MAIANSKI, N. A.; GEISSIER, J.; SRINIVASULA, S. M.; ALNEMRI, E. S.; ROSS, D.; KUIJPERS, T. W. Functional characterization of mitochondria in neutrophils: a role restricted to apoptosis. Cell Death and Differentiation, v. 11, p. 43-153, 2004. 
MALHOTRA, D. J.; KAUFMAN J. R. Endoplasmatic reticulum stress and oxidative stress: a vicious cycle or a double-edged sword? Antiox Redox Signal., v. 9, p. 2277-2293, 2007.

MARHOFFER, W.; STEIN, M.; MAESER, E.; FEDERLIN, K. Impairment of polymorphonuclear leukocyte function and metabolic control of diabetes. Diabetes Care, v. 15, p. 256-260, 1992.

MARKERT, M.; CECH, P.; FREI J. Oxygen metabolism of phagocytosing human polymorphonuclear leukocytes in diabetes mellitus. Blut, v. 49, p. 447-455, 1984.

MARTINS, J. O.; FERRACINI, M.; ANGER, D. B.; MARTINS, D. O.; RIBEIRO, L. F., SANNOMIYA, P.; JANCAR, S. Signaling pathways and mediators in LPS-induced lung inflammation in diabetic rats: role of insulin. Shock, v. 33, n. 1, p. 76-82, 2010.

MARTINS, J. O.; MEYER-PFLUG, A. R.; ALBA-LOUREIRO, T. C.; MELBOSTAD, H.; MIRANDA, W.; COIMBRA, R.; CURI, R.. Modulation of lipopolysaccharide-induced acute lung inflammation: role of insulin. Pharmacia, v. 25, n. 3, p. 260-266, 2006.

MARTINS, J. O.; ZANONI, F. L.; MARTINS, D. O.; COIMBRA, R.; KRIEGER, J. E.; JANCAR, S.; SANNOMIYA, P. Insulin regulates cytokines and intercellular adhesion molecule-1 gene expression through nuclear factor-kappaB activation in LPS-induced acute lung injury in rats. Shock, v. 31, n. 4, p. 404-409, 2009.

MEISCHL, C.; ROOS, D. The molecular basis of chronic granulomatous disease. Springer Semin. Immunopathol., v. 19, n. 417-434, 1998.

MOHANTY, P.; HAMOUDA, W.; GARG, R.; ALJADA, A.; GHANIM, H.; DANDONA, P. Glucose challenge stimulates reactive oxygen species (ROS) generation by leucocytes. J Clin Endocrinol Metab., v. 85, p. 2970-2973, 2000.

MOWAT, A.G.; BAUM, J. Chemotaxis of polymorphonuclear leukocytes from patients with diabetes mellitus. N. Engl. J. Med., v. 284, n. 621-627, 1971.

MUdD, J.; MCCUTCHEOn, M.; LUCKE, B. Phagocytosis. Physiol. Rev., v. 14, n. 210, 1934.

MYSLIWSKA, J.; ZORENA, K.; BAKOWSKA, A.; SKURATOWICZ-KUBICA, A.; MYSLIWSKI, A. Significance of tumor necrosis factor alpha in patients with long-standing Type-I diabetes mellitus. Horm Metab Res., v. 30, p. 158-161, 1998.

NÉMETH T.; MÓCSAI, A. The role of neutrophils in autoimmune diseases, Immunol Lett., v. 143, n. 1, p. 9-19, 2012.

NIELSEN, C. P.; HINDSON, D. A. Inhibition of polymorphonuclear leukocyte respiratory burst by elevated glucose concentrations in vitro. Diabetes, v. 38, n. 8, p. 1031-1035, 1989.

NISIMOTO, Y.; MOTALEBI, S.; HAN, C. H.; LAMBETH, J. D. The p67(phox) activation domain regulates electron flow from NADPH to flavin in flavocytochrome b(558). J. Biol. Chem., v. 274, n. 33, p. 22999-30005, 1999. 
NOLAN, C. N.; BEATY, H. N.; BAGDADE, J. D. Further characterization of the impaired bactericidal function of granulocytes in patients with poorly controlled diabetes. Diabetes, v. 27, p. 889-894, 1978.

OLDENBORG, P. A.; SUNDQVIST, I. M.; SEHLIN, J. Different effects of glucose on extracellular and intracellular respiratory burst response in normal human neutrophils activated with the soluble agonist fMet-Leu-Phe. Diabet Med., v. 17, p. 532-537, 2000.

OLEFSKY, J. M. Pathogenesis of non-insulin dependent diabetes (type 2). In: DEGROOT, L. J.; BESSER, G. M.; CAHILL, J. C. (Ed.). Endocrinology. 2nd ed. Philadelphia: Saunders, 1989. p. 1369-1388.

ORLINSKA, U.; NEWTON, R. C. Role of glucose in interleukin-1 beta production by lipopolysaccharide-activated human monocytes. J. Cell Physiol., v. 157, p. 201-208, 1993.

PAAPE, M. J.; SHAFER-WEAVER, K.; CAPUCO, A. V.; VAN OOSTVELDT, K.; BURVENICH, C. Immune surveillance of mammary tissue by phagocytic cells. Adv. Exp. Med. Biol., v. 480, p. 259-277, 2000.

PAN, G.; O'ROURKE, K.; DIXIT, V. M. Caspase-9, Bcl-XL, and Apaf-1 form a ternary complex. J. Biol. Chem., v. 273, p. 5841-5845, 1998.

PARKOS, C. A.; ALLEN, R. A.; COCHRAINE, C. G.; Jesaitis, A. J. Purified cytochrome b from human granulocyte plasma membrane is comprised of two polypeptides with relative molecular weights of 91,000 and 22,000. J. Clin. Invest., v. 80, n. 3, p. 732-742, 1987.

PEREIRA, M. A. A.; SANNOMIYA, P.; GARCIA-LEME, J. Inhibition of leukocyte chemotaxis by factor in alloxan-induced diabetic rat plasma. Diabetes, v. 36, p. 1307-1314, 1987.

PEREZ, J. F.; CHEMELLO, M. E.; LIPRANDI, F.; RUIZ, M. C.; MICHELANGELI, F. Oncosis in MA104 cells is induced by rotavirus infection through an increase in intracellular Ca2+ concentration. Virology., v. 252, v. 17-27, 1998.

PERNER, A.; NIELSEN, S. E.; RASK-MADSEN, J. High glucose impairs superoxide production from isolated blood neutrophils. Intensive Care Med., v. 29, p. 642-645, 2003.

PFAFFL, M. W. A new mathematical model for relative quantification in real-time RT-PCR. Nucleic Acids Res., v. 29, n. 9, e45, 2001.

PICKUP, J. C.; CROOK, M. A. Is type II diabetes mellitus a disease of the innate immune system? Diabetologia, v. 41, p. 1241-1248, 1998.

PRINCE, L. R.; WHYTE, M. K.; SABROE, I.; PARKER, L. C. The role of TLRs in neutrophil activation. Curr. Opin. Pharmacol., v. 11, n. 4, p. 397403, 2011.

QUINN, M. T.; EVANS, T.; LOETTERLE, L. R.; JESAITIS, A. J.; BOKOCH, G. M. Translocation of Rac correlates with NADPH oxidase activation. Evidence for equimolar translocation of oxidase components. J. Biol. Chem., v. 268, n. 28, p. 20983-20987, 1993. 
QUINN, M. T.; PARKOS, C. A.; WALKER, L.; ORKIN, S. H.; DINAUER, M. C.; JESAITIS, A. J. Association of a Ras-related protein with cytochrome $b$ of human neutrophils. Nature, v. 342, n. 6246, p. 198-200, 1989.

RAAM B. J.; VERHOEVEN A. J.;. KUIJPERS T. W. Mitochondria in Neutrophil Apoptosis; International Journal of Hematology, v. 84, p. 199-204, 2006.

RAMOS, C. L.; POU, S.; BRITIGAN, B. E.; COHEN, M. S.; ROSEN, G. M. Spin trapping evidence for myeloperoxidase-dependent hydroxyl radical formation by human neutrophils and monocytes. J. Biol. Chem., v. 267, p. 8307-8312, 1992.

RAYFIELD, E. J.; AULT, M. J.; KEUSCH, G. T.; BROTHERS, M. J.; NECHEMIAS, C.; SMITH H. Infection and diabetes: the case for glucose control. Am. J. Med., v. 72, p. 439$450,1982$.

REN, Y.; SAVILL, J. Proinflammatory cytokines potentiate thrombospondin-mediated phagocytosis of neutrophils undergoing apoptosis. J. Immunol., v. 154, n. 5, p. 2366-2374, 1995.

REPINE, J. E.; CLAWSON, C. C.; GOETZ F. C. Bactericidal function of neutrophils from patients with acute bacterial infections and from diabetics. J. Infect. Dis., v. 142, n. 6, p. 869$875,1980$.

RIMELE, T. J.; STURM, R. J.; ADAMS, L. M.; HENRY, D. E.; HEASLIP, R. J.; WEICHMAN, B. M.; GRIMES, D. Interaction of neutrophils with vascular smooth muscle: identification of a neutrophil-derived relaxing factor. J. Pharmacol. Exp. Ther., v. 245, p. 102-111, 1988.

RIZZUTO, R.; DUCHEN, M. R.; POZZAN, T. Flirting in little space: the ER/mitochondria Ca2+ liaison. Sci. STKE., n. 215, p. 232-241, 2004.

ROMERO-CALVO, I.; OCÓN, B.; MARTÍNEZ-MOYA, P.; SUÁREZ, M. D.; ZARZUELO, A.; MARTÍNEZ-AUGUSTIN, O.; DE MEDINA, F. S. Reversible Ponceau staining as a loading control alternative to actin in Western blots. Anal Biochem., v. 15, v. 401, n. 2, p. 318-320, 2010.

RON, D.; WALTER, P. Signal integration in the endoplasmatic reticulum unfolded protein response. Nature Rev., v. 8; p. 519-529, 2007.

ROSSI, A. G.; MCCUTCHEON, J. C.; ROY, N.; CHILVERS, E. R.; HASLETT, C.; DRANSFIELD, I. Regulation of macrophage phagocytosis of apoptotic cells by cAMP. J. Immunol., v. 160, n. 7, p. 3562-3568, 1998.

ROSSI, F.; ZATTI, M. Biochemical aspects of phagocytosis in polymorphonuclear leucocytes. NADH and NADPH oxidation by the granules of resting and phagocytizing cells. Experientia, v. 20, n. 1, p. 21-23, 1964.

SAFTIG, P.; BEERSTEN, W.; ESKELINEN, E. L. LAMP-2: a control step for phagosome and autophagosome maturation. Autophagy, v. 4, p. 510-512, 2008. 
SAGONE, A. L.; GREENWALD J.; KRAUT, E. H.; BIANCHINE, J.; SINGH D. Glucose: a role as a free radical scavenger in biological systems. J. Lab. Clin. Med., v. 101, p. 97-104, 1983.

SANNOMIYA, P.; OLIVEIRA, M. A.; FORTES Z. B. Aminoguanidine and the prevention of leukocyte dysfunction in diabetes mellitus: a direct vital microscopic study. Br. J. Pharmacol., v. 122, p. 894-898, 1997.

SANNOMIYA, P.; PEREIRA, M. A. A.; GARCIA-LEME, J. Inhibition of leukocyte chemotaxis by serum factor in diabetes mellitus: selective depression of cell responses mediated by complement-derived chemoattractants. Agents and Actions, v. 30, p. 369-376, 1990.

SANO, R.; REED J. C. ER stress-induced cell death mechanisms. Biochim Biophys Acta, v. 4889, n. 13, p. 251-256, 2103.

SANTOS, C. X.; TANAKA, L. Y.; WOSNIAK, J.; LAURINDO, F. R. Mechanisms and implications of reactive oxygen species generation during the unfolded protein response: roles of endoplasmic reticulum oxidoreductases, mitochondrial electron transport, and NADPH oxidase. Antioxid. Redox Signal, v. 11, p. 2409-2427, 2009.

SATOMI, N.; SAKURAI, A.; HARANAKA, K. Relationship of hypoglycemia to tumor necrosis factor production and antitumor activity: role of glucose, insulin, and macrophages. J. Natl. Cancer Inst., v. 74, p. 1255-1260, 1985.

SAVILL, J.; HASLETT, C. Granulocyte clearance by apoptosis in the resolution of inflammation. Semin. Cell Biol., v. 6, n. 6, p. 385-393, 1995.

SCHRODER, M.; KAUFMAN, R. J. The mammalian unfolded protein response. Annu. Rev. Biochem., v. 74, p. 739-789, 2005.

SHIMIZU, Y.; HENDERSHOT, L. M. Oxidative folding: cellular strategies for dealing with the resultant equimolar production of reactive oxygen species. Antioxid. Redox Signal, v. 11, n. 9, p. 2317-2331, 2009.

SHIOSE, A.; SUMIMOTO, H. Arachidonic acid and phosphorylation synergistically induce a conformational change of p47phox to activate the phagocyte NADPH oxidase. J. Biol. Chem., v. 275, p. 13793-13801, 2000.

SIMMEN, T.; ASLAN, J. E.; BLAGOVESHCHENSKAYA A. D.; THOMAS, L.; WAN, L.; XIANG, Y.; FELICIANGELI, S. F.; HUNG, C. H.; CRUMP, C. M., Thomas G. PACS-2 controls endoplasmic reticulum-mitochondria communication and Bid-mediated apoptosis. Embo J., v. 24, p. 717-729, 2005.

SIMMEN, T.; LYNES, E. M.; GESSON, K.; THOMAS, G. Oxidative protein folding in the endoplasmic reticulum: Tight links to the mitochondria-associated membrane (MAM). Bioch. Biophys. Acta, v. 1798, n. 8, p. 1465-73. 2010 
STURM, R. J.; HOLLOWAY, D. A.; BUCKLEY, S.; OSBORNE, M. C.; GRIMES, D.; WEICHMAN, B. M. e RIMELE, T. J. Potential regulatory role of inflammatory cells on local vascular smooth muscle tone. Agents Acta, v. 27, p. 414-417, 1989.

SZABADKAI, G.; BIANCHI, K.; VÁRNAI, P.; DE STEFANI, D.; WIECKOWSKI, M. R.; CAVAGNA, D.; NAGY, A. I.; BALLA, T.; RIZZUTO, R. Chaperone-mediated coupling of endoplasmatic reticulum and mitochondrial Ca2+ channels. J. Cell Biol., v. 175, p. 901911, 2006.

TABAS,I.; RON,D.Integrating the mechanisms of apoptosis induced by endoplasmic reticulu m stress. Nat. Cell Biol., v. 13, n. 3, p. 184-190, 2011.

TAN, J. S.; ANDERSON, J. L.; WATANAKUNAKORN, C.; PHAIR, J. P. Neutrophil dysfunction in diabetes mellitus. Clin. Experim., v. 85, n. 1, p. 26-33, 1975.

TANG, C.; KOULAJIAN, K.; SCHUIKI, I.; ZHANG, L.; DESAI, T.; IVOVIC, A.; WANG, P.; ROBSON-DOUCETTE, C.; WHEELER, M. B.; MINASSIAN, B.; VOLCHUK, A.; GIACCA, A. Glucose-induced beta cell dysfunction in vivo in rats: link between oxidative stress and endoplasmic reticulum stress. Diabetologia, v. 55, n. 5, p. 1366-79, 2012.

TATER, D.; TEPAUT, B.; BERCOVICI, J. P.; YOUINOU, P. Polymorphonuclear cell derangements in Type I diabetes. Horm. Metab. Res., v. 19, p. 642-647, 1987.

THOMAS, E. L.; LEARN, D. B. Myeloperoxidase-catalyzed oxidation of chloride and others halides: The role of chloramines. In: EVERSE, J.; EVERSE, K. E.; GRISHAM, M. B. (Ed.). Peroxidases in chemistry and biology. Boca Raton: CRC, 1991. p. 83-87.

THOMPSON, C. B. Apoptosis in the pathogenisis and treatment of disease. Science, v. 267, p. 1456-1462, 1995.

THORENS, B.; MUECKLER M. Glucose transporters in the 21st Century. Am. J. Physiol. Endocrinol. Metab., v. 298, n. 2, p. 141-145, 2010.

TODD, D. J.; LEE, A-H.; GLIMCHER, L. H. The endoplasmatic reticulum stress response in immunity and autoimmunity. Nat. Rev. Immunol., v. 8, p. 663-674, 2008.

TONNESEN, M. G. Neutrophil-endothelial cell interactions: mechanisms of neutrophil adherence to vascular endothelium. J. Invest. Dermatol., v. 93, p. 53-58, 1989.

TOWBIN, H.; STAEHELIN, T.; GORDON, J. Electrophoretic transfer of proteins from polyacrylamide gels to nitrocellulose sheets: procedure and some applications. Proc. Natl. Acad. Sci. USA., v. 76, p. 4350-4354, 1979.

TRUMP, B. F.; BEREZESKY, I. K. The role of altered [Ca2+]i regulation in apoptosis, oncosis, and necrosis. Biochem. Biophys. Acta, v. 1313, p. 173-178, 1996.

TSUJIMOTO, Y.; SHIMIZU, S. Bcl-2: Life-or-death switch. FEBS Lett., v. 466, p. 6-10, 2000 . 
UEDA, S.; MASUTANI, H.; NAKAMURA, H.; TANAKA, T.; UENO, M.; YODOI, J. Redox control of cell death. Antioxid. Redox Signal., v. 4, n. 3, p. 405-414, 2002.

URANO, F.; WANG, X.; BERTOLLI, A.; ZHANG, Y.; CHUNG, P.; HARDING, H. P.; RON, D. Coupling of stress in the ER to activation of JNK protein kinases by transmembrane protein kinase 1 IRE1. Science, v. 287, p. 664-666, 2000.

VAN RAAM, B. J.; VERHOEVEN, A. J.; KUIJPERS, T. W. Mitochondria in neutrophil apoptosis. Int. J. Hematol., v. 84, n. 3, p. 199-204, 2006.

VANHOLDER, R.; HSU, C.; RINGOIR, S. Biochemical definition of the uremic syndrome and possible therapeutic implications. Artif. Organs., v. 17, n. 4, p. 234-239, 1993.

VANHOLDER, R.; VAN BIESEN, W.; RINGOIR, S. Contributing factors to the inhibition of phagocytosis in hemodialyzed patients. Kidney Int., v. 44, n. 1, p. 208-214, 1993 b.

VERMES, I.; HAANEN, C.; STEFFENS-NAKKEN, H.; REUTELINGSPERGER, C. A novel assay for apoptosis. Flow cytometric detection of phosphatidylserine expression on early apoptotic cells using fluorescein labelled Annexin V. J. Immunol. Methods., v. 184, n. 1, p. 39-51, 1995.

VOELTZ, G. K.; ROLLS, M. M.; RAPOPORT T. A. Strucutural Organizantion of the endoplasmatic reticulum. EMBO Rep., v. 3, p. 944-950, 2002.

WALRAND, S.; GUILLET, C.; BOIRIE, Y.; VASSON, M. In vivo evidences that insulin regulates human polymorphonuclear neutrophil functions. J. Leukoc. Biol., v. 76, p. 11041110, 2004.

WANG, X. Z.; HARDIG, H. P.; ZHANG, Y.; JOLICOUER, E. M.; KURODA M.; RON, D. Cloning of mammalian Ire1 reveals diversity in the ER stress responses. Embo J., v. 17, p. 5708-5717, 1998.

WARD, P. A. Leukotaxis and leukotactic disorders. Am. J. Pathol., v. 77, p. 520-538, 1974.

WELCH, H. C.; CODWELL, W. J.; ELLSON, C. D.; FERGUNSON, G. J.; ANDREWS, S. R.; ERDJUMENT-BROMAGE, H.; TEMPST, P.; HAWKINS, P. T.; STEPHENS, L. R. PRex1, a PtdIns $(3,4,5) \mathrm{P} 3$ - and G $\beta \gamma$-regulated guanine-nucleotide exchange factor for Rac. Cell, v. 108, p. 809-821, 2002.

WIERUSZ-WYSOCKA, B.; WYKRETOWICZ, A.; KLIMAS, R. The influence of increasing glucose concentrations on selected functions of polymorphonuclear neutrophils. Acta Diabetol. Lat., v. 25, p. 283-288, 1988.

WIERUSZ-WYSOCKA, B.; WYSOCKI, H.; WYKRETOWICZ, A.; SZCZEPANIK, A.; SIEKIERKA, H. Phagocytosis, bactericidal capacity, and superoxide anion (O2-) production by polymorphonuclear neutrophils from patients with diabetes mellitus. Folia Haematol., v. 112, n. 5S, p. 658-668, 1985.

WILSON, R. M.; REEVES, W. G. Neutrophil phagocytosis and killing in insulin-dependent diabetes. Clin. Exp. Immunol., v. 63, n. 2, p. 478-484, 1986. 
WITKO-SARSAT, V.; REUTER, N. ; MOUTHON, L. Interaction of proteinase 3 with its associated partners: implications in the pathogenesis of Wegener's granulomatosis. Curr Opin Rheumatol., v. 22, n. 1, p. 1-7, 2010.

WITKO-SARSAT, V.; RIEU, P.; DESCAMPS-LATSCHA, B.; LESAVRE, P.; HALBWACHS-MECARELLI, L. Neutrophils: molecules, functions and pathophysiological aspects. Lab. Invest., v. 80, n. 5, p. 617-653, 2000.

WOLFF, S. P. Diabetes mellitus and free radicals. Brit. Med. Bull., v. 49, n. 3, p. 642-652, 1993.

WOSNIAK J. R. J.; SANTOS, C. X. C.; KOWALTOWSKI, A. J.; LAURINDO, F. R.; Crosstalk between mitochondria and NADPH oxidase: Effects of mild mitochondiral dysfunction on agiotensin II-mediated increase in Nox isoform expression and activity in vascular smooth muscle cells. Antiox Redox Signal., v. 11, p. 1265-1278, 2009.

XU, L.; VOlOBOUEVA, L. A.; OUYANG, Y.; EMERY, J. F.; GIFFARD, R. G. Overexpression of mitochondrial Hsp70/Hsp75 in rat brain protects mitochondria, reduces oxidative stress, and protects from focal ischemia. J. Cereb. Blood Flow Metab., v. 29, p. 365-374, 2009.

YI, S.; BHATE, C.; SCHWARTZ, R. A. Sweet's syndrome: an update and review. G. Ital. Dermatol. Venereol., v. 144, n. 5, p. 603-612, 2009.

YOSHIDA, H.; MATSUI, T.; HOSOKAWA, N.; KAUFMAN, R. J.; NAGATA, K.; MORI K. A. Time dependent phase shift in the mamalian unfolded protein response. Dev. Cell., v. 4, p. 265-271, 2003.

YU, L.; ALVA, A.; SU, H.; DUTT, P.; FREUNDT, E.; WELSH, S. Regulation of an ATG7beclin 1 program of autophagic cell death by caspase-8. Science, v. 304, p. 1500-1502, 2004.

ZHANG, X.; DING, L.; SANDFORD, A. J. Selection of reference genes for gene expression studies in human neutrophils by real-time PCR. BMC Mol. Biol., v. 6, n. 1, p. 4-10, 2005.

ZINSZNER, H.; KURODA, M.; WANG, X.; BATCHVAROVA, N.; LIGHTFOOT, R. T.; REMOTTI, H.; STEVENS, J. L.; RON, D. CHOP is implicated in programmed cell death in response to impaired function of the endoplasmic reticulum. Genes Dev., v. 12, n. 7, p. 982995, 1998.

ZOZULINSKA, D.; MAJCHRZAK, A.; SOBIESKA, M.; WIKTOROWICZ, K.; WIERUSZWYSOCKA, B. Serum interleukin-8 level is increased in diabetic patients. Diabetologia., 42: 117-118, 1999. Goto Y, Kakizaki M, Masaki N. Production of spontaneous diabetic rats by repetition of selective breeding. Tohoku J. Exp. Med., v. 119, p. 85-90, 1976. 
APÊNDICE A - Membranas coradas com ponceau para normalização das bandas

Exemplo de membrana corada com ponceau em escala de cinza para normalização das análises das densidades ópticas das bandas obtidas por WB.

ㅁ 0

무

ㅁ ㅁ

De acordo com Aldridge et al., uma região de cada faixa de corrida foi selecionada para obtenção da densidade óptica (OD) pelo programa Image ${ }^{\circledR}$. A OD da banda correspondente à proteína de interesse obtida por quimioluminescência foi normalizada pela densidade óptica da faixa correspondente. Segundo Aldrige et al. (2008) e Romero-Calvo et al., essa normalização é mais eficiente do que a normalização por $\beta$ actina, especialmente se a quantidade de proteína aplicada no gel ultrapassa $50 \mu \mathrm{g}$. 
APÊEDICE B - Trabalho submetido à PLoS ONE referente ao projeto BEPE

Paper referente ao projeto de Bolsa de auxílio à Pesquisa no Exterior (BEPE-FAPESP) submetido à PLoS ONE no dia 18/07/2013.

Número: PONE-D-1329943

O projeto BEPE foi desenvolvido nos laboratórios dos professores Dr. Allen Volchuk (Universidade de Toronto, ON, Canadá) e Dr. Sergio Grinstein (Sickkids Hospital, ON, Toronto)

Esse projeto recebeu o apoio financeiro da FAPESP.

Número do processo: 2012/05349-9

Vigência: 23/07/2012 a 22/01/2013 (6 meses) 


\section{PLOS ONE: A manuscript number has been assigned to NADPH Oxidase-Dependent Production of Reactive Oxygen Species induces Endoplasmatic Reticulum Stress in Neutrophil-like cells.}

De : PLOS ONE <plosone@plos.org>

Remetente : em pone $034 a 76 f$ 89780a92 <em.pone.0.34a76f.89780a92@editorialmanager.com>

Assunto : PLOS ONE: A manuscript number has been assigned to NADPH Oxidase-Dependent Production of Reactive Oxygen Species induces Endoplasmatic Reticulum Stress in Neutrophil-like cells.

Para : Wilson Mitsuo Tatagiba Kuwabara <wilsonk@icb.usp.br>

Dear Mr. Kuwabara,

On Jul 182013 10:42PM, we received your Research Article entitled "NADPH Oxidase-Dependent Production of Reactive Oxygen Species induces Endoplasmatic Reticulum Stress in Neutrophil-like cells." by Wilson Mitsuo Tatagiba Kuwabara; Liling Zhang; Irmgard Schuiki; Rui Curi; Allen Volchuk; Tatiana Carolina Alba-Loureiro.

Your manuscript has been assigned the manuscript number: PONE-D-13-29943.

We will keep you informed about the progress of your manuscript or you can check the status by logging into your account.

Please be aware that you will NOT be required to complete the 'Open-Access Agreement' field until your manuscript is accepted for publication. You may also be asked to provide your article and figure files in a different format at this time (please see the 'Format Requirements' section of the Manuscript Guidelines for more information:

http://www.plosone.org/static/quidelines.action\#format)

Please visit everyONE (http://blogs.plos.org/everyone), the PLOS ONE community blog for authors who have published with us (as well as our readers), where you will be able to find out what the journal is thinking, changing and doing.

Thank you for submitting to PLOS ONE.

If you have any inquiries or other comments regarding this manuscript, please contact plosone@plos.org.

Thank you for choosing PLOS ONE.

Best wishes,

PLOS ONE 


\section{NADPH Oxidase-Dependent Production of Reactive Oxygen Species induces Endoplasmatic Reticulum Stress in Neutrophil-like cells.}

Wilson MitsuoTatagiba Kuwabara ${ }^{a}$, Liling Zhang $^{b}$, Irmgard Schuiki $i^{b}$, Rui Curi ${ }^{a}$, Allen Volchuk ${ }^{b}$ and Tatiana Carolina Alba Loureiro ${ }^{a}$

${ }^{a}$ Department of Physiology and Biophysics - Institute of Biomedical Sciences - University of São Paulo, São Paulo, Brazil.

${ }^{b}$ Division of Cellular and Molecular Biology, Toronto General Research Institute, University Health Network, ON M5G 1L7, Canada.

\section{Abstract}

ROS primarily produced via NADPH oxidase play an important role for killing microorganisms in neutrophils. In this study we examined if ROS production in Human promyelocytic leukemia cells (HL60) differentiated into neutrophil-like cells (dHL60) induce ER stress and activation of the unfolded protein response (UPR) and whether this is dependent on NADPH oxidase activity. To induce ROS production cells were treated with PMA or by chronic hyperglycemia. Chronic hyperglycemia however, failed to induce ROS production and did not cause activation of the UPR. PMA, a pharmacologic NADPH oxidase activator, induced ER stress in dHL60 cells, in a manner that is independent of calcium signaling. NADPH oxidase inhibitor, Diphenyleneiodonium (DPI), abolished both ROS production and UPR activation. These results show that ROS produced by NADPH oxidase induce ER stress by PERK and IRE1 pathways in dHL60 cells, and this process is independent of calcium mobilization.

\section{Introduction}

Neutrophils are essential components of the innate immune system and have an important role in initiating and sustaining the inflammatory process. These cells synthesize proteins that participate in their own effector functions and in the inflammatory response, such as polypeptides, cytokines, chemokines, growth factors and interferons [1]. Neutrophils depend on the activation of NADPH oxidase [2] and hence the generation of reactive oxygen species (ROS) for their microbicidal activity [3; 4]. The dead neutrophils ingestion by macrophages is the main mechanism to remove neutrophils recruited to the inflamed site and, then, to promote the resolution of inflammation [5]. The high demand for the production of proteins and inflammatory responses require the endoplasmatic reticulum (ER), an important organelle to maintain cell homeostasis [6].

The ER is present in all eukaryotic cells. All proteins transiting the secretory pathway in the cells first enter the ER, undergo conformational changes, form complexes and are exported in vesicles to the Golgi apparatus for subsequent secretion. The ER has a unique microenvironment that favors the correct formation of proteins from the very beginning, when the nascent polypeptide chains enter the ER lumen. ER is also the primary intracellular calcium store. Both the formation of new proteins and the function performed by chaperones require high levels of intraluminal calcium [7]. Impairment in ER function results in ER stress, alteration in calcium 
signaling and redox dysfunction. The accumulation of unfolded proteins leads to activation of a signaling cascade known as the Unfolded Protein Response (UPR). The UPR is detailed in some reviews [8; 9; 10;11]. Briefly, the ER stress response involves activation of three ER components: Inositol-Requiring kinase 1 (IRE1), double-stranded RNA-activated protein kinase-like ER kinase (PERK) and Activating transcription factor 6 (ATF6) $[7 ; 12 ; 13]$. When the unfolded protein concentration increases in the lumen of the ER, the chaperone GRP78 or Bip dissociates from PERK, IRE1 and ATF6 to bind to the unfolded proteins and prevent agglomeration. This causes the activation of these branches as follows: IRE1 oligomerize with other molecules of IRE1, leading to autophosphorylation of its cytoplasmic domain and consecutive activation of the IRE1 ribonuclease (RNAse) [10]. This RNase cleaves XBP1 (X-box binding protein) mRNA to remove an intron of 26 nucleotides. The result of the removal of the 26 introns is the spliced XBP1 (sXBP1) that activates the transcription of several genes involved in the UPR. PERK dimerizes and autophosphorylates itself, leading to activation of the kinase elF2 $\alpha$ (eukaryotic translation factor $2 \alpha$ ) by phosphorylation on Ser51. [7]. Although the phosphorylation of elF2 $\alpha$ inhibits general protein synthesis, it is necessary for translation of various mRNAs. A transcription factor whose translation is activated by phosphorylation of elF2 $\alpha$ is ATF4 (Activating Transcription Factor 4) [12], which belongs to the CREB (cAMP-response element binding) family and activates several genes involved in the control of UPR, including chaperones like Bip and GRP94, and also genes involved in the suppression of oxidative stress, metabolism and transport of aminoacids. ATF6 is translocated to the Golgi apparatus where it is cleaved by Site-1 (S1P) and Site-2 (S2P) proteases that release the $50-\mathrm{kDa}$ domain as an active transcription factor (ATF650). The ATF650 migrates to the nucleus and activates the transcription of several genes involved in ER quality control [10;13].

Reactive Oxygen Species (ROS) may activate UPR by changing the redox state in the ER lumen. ROS are produced by the ER during basal cell metabolism and it is increased during ER stress [14; 15]. Several cell types, especially phagocytes as neutrophils, express proteins of the Nox family and produce ROS by using NADPH $[15 ; 16 ; 17]$. The NADPH oxidase is an enzyme complex consisting of cytoplasmic proteins ( $\mathrm{p} 40^{\text {phox }}, \mathrm{p} 47^{\text {phox }}$ and $\mathrm{p} 67^{\text {phox }}$ ) and membrane proteins (gp9 $1^{\text {phox }}$ or Nox2 and p22 ${ }^{\text {phox }}$ ) to form a flavo-hemoprotein known as cytochrome b558 [18; 19]. NADPH oxidase transfers the electron of the complex to the oxygen molecule in the phagosome or in the cytosol, generating superoxide anion $[20 ; 21 ; 22 ; 23]$ and hydrogen peroxide, which is formed by spontaneous dismutation or by superoxide dismutase (SOD) activity [3; 24]. Most of the generated hydrogen peroxide is consumed by neutrophil myeloperoxidase [25; 26]. This enzyme catalyzes the formation of $\mathrm{HOCl}$ by oxidation of chloride ions [27; 28], the primary oxidant bactericidal agent produced by neutrophils [23; 29]. Increasing evidence show that ROS produced by the NADPH oxidase are important mediators in the activation of the ER stress [14; 15; 30; 31; 32].However, the contribution of NADPH oxidase in the setting of the ER stress in neutrophils has never been studied. Thus, the aim of this study was to examine if ROS produced through NADPH oxidase cause ER stress and activate UPR in neutrophil-like cells. We found that activation of NADPH oxidase by Phorbol-12-Myristate-13-Acetate (PMA) stimulation produced an increase in ROS, induced ER stress and activation of UPR. 


\section{Materials and Methods}

\section{HL60 Cell Culture and differentiation}

Human HL-60 cells were obtained from American Type Culture Collection (ATCC) (Manassas, VA, USA)and grown in endotoxin-free RPMI 1640 medium containing $5.5 \mathrm{mM}$ glucose, $10 \%$ heat-inactivated FBS at $37^{\circ} \mathrm{C}$ in a $5 \% \mathrm{CO}_{2}$ atmosphere. Media was changed every 3 days. To differentiate HL60 cells into neutrophil-like cells (dHL60), $1.25 \%$ DMSO was added to the media for 6 days as previously reported [3, 4]. After the differentiation, dHL-60 cells $\left(1 \times 10^{6} \mathrm{cells} / \mathrm{ml}\right)$ were cultured for $24 \mathrm{~h}$ in 5.5 $\mathrm{mM}$ [normal glucose (NG)] or $25 \mathrm{mM}$ glucose (HG). The nonphysiological sugar, 19.5 $\mathrm{mM}$ mannitol (MN), was used to examine the impact of the osmotic pressure exerted by glucose.

\section{Flow cytometry analysis}

To assess the production of ROS, dHL60cells were labeled with $10 \mu \mathrm{M}$ DHR 123 (Dihydrorhodamine 123) and stimulated with $200 \mathrm{nMPMA}$ or PMA+ DPI $(10 \mu \mathrm{M})$ (Diphenyleneiodonium). For flow cytometric quantification of ROS, cells $\left(1.5 \times 10^{6}\right)$ were incubated or not with DPI for 20 min before the stimulus with PMA. PMA was added 15 min before the analysis. Undifferentiated HL60 cells were used as negative control. Following treatments, flow cytometric analyses were conducted on a FACSLSRII (Becton Dickinson, San Jose, CA, USA) flow cytometer. Cells were excited using laser line at $488 \mathrm{~nm}$. The emission filter setup was the band pass filter 510/20. Data analysis was performed using the BD FACS Diva software version 6.0.

\section{Intracellular calcium concentration}

dHL60 cells $\left(1.5 \times 10^{6}\right)$ were incubated for $24 \mathrm{~h}$ under the following conditions: NG, $\mathrm{HG}$ and MN. Then, cells were labeled with Indo-1-AM $(5 \mu \mathrm{M})$ for one hour at $37^{\circ} \mathrm{C}$. After incubation, cells were washed with $\mathrm{Ca}^{2+}$ buffer $(150 \mathrm{mM} \mathrm{NaCl}, 4 \mathrm{mM} \mathrm{KCl}, 25 \mathrm{mM}$ HEPES, 3mM CaCl2, $5 \mathrm{mM}$ pyruvate, $10 \mathrm{mM}$ glucose, $\mathrm{pH} 7.3$ ) and kept at room temperature prior to analysis. For calcium influx measurements, dHL60 were resuspended in $\mathrm{Ca}^{2+}$ buffer with $1 \mathrm{mg} / \mathrm{mL}$ albumin (BSA). For ER calcium content, cells were washed and kept in $\mathrm{Ca}^{2+}$ free buffer $(150 \mathrm{mM} \mathrm{NaCl}, 4 \mathrm{mM} \mathrm{KCl}, 25 \mathrm{mM}$ HEPES, $5 \mathrm{mM}$ pyruvate, $10 \mathrm{mM}$ glucose, $2 \mathrm{mM}$ EGTA, pH7.3). After labeling the cells with Indo-1-AM, the intracellular calcium changes were monitored by fluorimetry ( $F$ 2500, HITACHI) at $37^{\circ} \mathrm{C}$ under constant agitation. PMA $(1 \mu \mathrm{M})$ or fMLP $(1 \mu \mathrm{M})$ were tested to change calcium influx. The ionophore, ionomycin $(1 \mu \mathrm{M})$, was used in the ER calcium content measurements and also to calibrate the curve with magnesium chloride $(2 \mathrm{mM})\left(\mathrm{MnCl}_{2}\right)$. Intracelular calcium was calculated as previouslyreported [33]. 
Total RNA was isolated from dHL60 cells $\left(1,5 \times 10^{6}\right)$ using TRIzol reagent (Invitrogen) and RNeasy ${ }^{\circledR}$ Mini Kit (Qiagen). The RNA was reverse transcribed to single-stranded cDNA using the High-Capacity cDNA reverse transcription kit (Applied Biosystems). The resulting cDNA was used for the PCR analysis.Human XBP-1 cDNA was amplified by OneStep RT-PCR kit (Qiagen) using primers that flank the intron excised by IRE1 exonuclease activity as previously described (21). Primer sequences used to amplify human XBP-1 were: 5'-TTA CGA GAG AAA ACT CAT GGC C-3'and 5'- GGG TCC AAG TTG TCC AGA ATG C -3'. The protocol used for the RT-PCR was as follows: $50{ }^{\circ} \mathrm{C}(30 \mathrm{~min}) ; 95^{\circ} \mathrm{C}(15 \mathrm{~min}) ; 35$ cycles of $94{ }^{\circ} \mathrm{C}(1$ $\min ), 55^{\circ} \mathrm{C}(1 \mathrm{~min}), 72{ }^{\circ} \mathrm{C}(1 \mathrm{~min}) ; 72{ }^{\circ} \mathrm{C}(10 \mathrm{~min})$. RT-PCR products were resolved on a $3 \%$ agarose gel and visualized using ethidium bromide.

\section{Western BlotAnalysis}

Cells $\left(1 \times 10^{7}\right)$ were transferred totubes and centrifuged at 1,200 rpm for $10 \mathrm{~min}$ at $4^{\circ} \mathrm{C}$. The pellet was washed with $1 \mathrm{ml}$ of cold phosphate-buffered saline (PBS) and centrifuged at $1,200 \mathrm{rpm}$ for $10 \mathrm{~min}$ at $4^{\circ} \mathrm{C}$. The pellet was resuspended in $60 \mu \mathrm{l}$ of Triton X100 lysis buffer. Proteins were resolved by SDS-PAGE and transferred to nitrocellulose membranes. The membranes were blocked for $1 \mathrm{~h}$ at room temperature with $5 \%$ skim milk and incubated with the specific primary antibodies overnight. Following incubation with secondary antibody conjugated to horseradish peroxidase, the bands were detected with the enhanced chemiluminescence system (Amersham Biosciences). Immunoblots were scanned and quantified using the Image ${ }^{\circledR}$ software. The following commercial primary antibodies were used:anti-phospho-elF2 $\alpha$ (catalog number 9721, 1:500; Cell Signaling), y-tubulin (T6557, 1:1000; Sigma).

\section{Data Analysis}

Results are presented as mean \pm S.E. Statisticalsignificance was found by two wayANOVA followed by theBonferroni test.p $\leq 0.05$ was considered statistically significant.

\section{$\underline{\text { Results }}$}

HL60 cellis a tumor cell line that was isolated from a single patient with acute promyelocytic leukemia and can be differentiated in vitro into a variety of blood cell types [34]. To differentiate them into neutrophils polar components such as DMSO or retinoic acid are used. After differentiation, although they are not identical to primary neutrophils, neutrophil-like cells (dHL60) express all the components of NADPH oxidase and its functionality is similar to primary neutrophils [34; 35; 36; 37].

HL60 cells differentiated into neutrophils were used as a model to study the effect of ROS production on ER stress and UPR activation. Although chronic hyperglycemia has been shown to increase ROS levels in various cell types [38; $39 ; 40 ; 41]$ it failed to increase ROS production in dHL60 cells as detected by DHR 123 [42](Figure 1a). However, we observed a 5-fold increase in ROS production after PMA stimulus in dHL60 cells but not by undifferentiated HL60 cells (Figure 1b). PMA activates PKC, which promotes the assembly of NADPH oxidase proteins [43].Undifferentiated HL60 cells were used as a negative control; since they do not 
express the nox proteins as much as dHL60 [44] and ROS production is not expected to be increased by PMA. However, as compared to the dHL60, undifferentiated HL60 have higher basal ROS levels, which reflect a higher metabolic rate $[15,45]$ (Figure 1b). ROS production stimulated by PMA in dHL60 cells is mostly NADPH oxidase dependent since DPI, a specific inhibitor of the NADPH oxidase [16], significantly inhibited ROS production (Figure 1b).

ER stress can be caused by depletion of ER calcium stores as is pharmacologically induced using thapsigargin [46]. To examine if PMA or high glucose affect cellular calcium levels, intracellular calcium dynamics were measured by using Indo-1-AM an ester of the calcium sensitive dye Indo-1[47].Ionomycin and $\mathrm{MnCl}_{2}$ were used to determine the maximum and the minimum concentration of intracellular calcium, respectively. These values are essential to calibrate the curve and calculate the final concentration of calcium induced by the stimuli [33].PMA did not cause any alteration in the calcium influx (Figure 2A) compared to fMLP used as a positive control (Figure 2B).Similarly, chronic hyperglycemia did not cause variations of the ER calcium content nor differences in the calcium influx when cells were stimulated with fMLP (Figure 2D-F).

Finally, we examined if ROS produced through NADPH-dependent induces ER stress in dHL60 cells. ER stress is inferred by monitoring activation of either ER stress sensors (PERK, IRE1, ATF6) or induction of UPR target genes [13]. To monitor activation of the PERK pathway we examined phosphorylation of elF2 $\alpha$, a target of the PERK kinase. dHL60 cells were treated with PMA for 1 and $4 \mathrm{~h}$ in the presence or absence of DPI and phospho-elF2a levels were measured by western blot analysis (Figure 3a). PMA lead to an increase in p-elF2alevels after 1 and 4 hour of stimulus and DPI completely inhibited this effect (Figure 3a) suggesting that PMA activated the PERK branch of the UPR through ROS produced by NADPH oxidase activation.

We also monitored activation of the IRE1 pathway by measuring spliced XBP1 mRNA levels by RT-PCR. Similarly, PMA increased the levels of spliced XBP-1 after 1 and $4 \mathrm{~h}$ of treatment and this effect was inhibited by DPI (Figure 3b). Thus, activation of the IRE1pathway by PMA is dependent on ROS production and not on PKC activation per se. Hyperglycemia, on the other hand, failed to cause UPR activation and there was no significant difference between the conditions after PMA stimuli (Figure 4).

\section{Discussion}

It has long been thought that neutrophils were terminally differentiated cells lacking activity of transcription and protein synthesis. In fact, neutrophils exhibit high ability to conduct de novo synthesis of various proteins such as cytokines and chemokines with immunomodulatory properties [1;48]. The ER of these cells is functional and should be considered as a key organelle in the viability of the cell, especially in the activated states, when the production of secretory proteins increases [49]. However, neutrophils when activated are also large producers of ROS primarily via NADPH oxidase. Given that ROS can induce ER stress $[14 ; 15 ; 30 ; 31$; 32], a situation that would increase unfolded and misfolded proteins in the ER, we sought to determine if this is the case. 
We found that dHL60 cells treated with the PKC activator PMA resulted in a large increase in ROS production that correlated with induction of ER stress markers (phosphorylation of elF2 $\alpha$; PERK pathway) and splicing of XBP1; IRE1 pathway). Importantly, DPI a specific inhibitor of the NADPH oxidase protein complex assembly, that does not inhibit PKC [43], prevented ROS induction and the activation of investigated ER stress markers.

Calcium participates in various cellular processes including: cell cycle, protein synthesis, gene expression, muscle contraction, secretion and apoptosis [50]. It is known that ER stress can also be caused by disturbances in ER calcium signaling. For instance, thapsigargin, a specific inhibitor of the ER Ca ${ }^{2}-A T P a s e$, depletes $\mathrm{Ca}^{2+}$ from the lumen of this organelle, resulting in activation of the UPR $[51 ; 52]$. Furthermore, ionomycin, an ionophore that opens the calcium channels of the cell, causes an increase in the influx of $\mathrm{Ca}^{2+}$, which promotes ER stress [53]. It is known that fMLP triggers ROS production in dHL60 and it is accompanied by an increased influx of calcium [54]. However, PMA did not induce calcium influx and, thus, the ER stress in dHL60 occurred independently of calcium changes, supporting the proposition that the activation of the UPR occurs only through ROS production.

dHL60 cell potently activates the UPR under conditions of ROS produced in excess by the NADPH-oxidase. We speculate that activation of the UPR may have dual effects depending on the NAPDH oxidase activation state and consequently on the levels of ROS. The UPR can potentially be induced by low levels of ROS to increase ER protein folding capacity to maintain secretory protein production. However, greater NAPDH oxidase activation (as occurs by PMA activation) may lead to rapid induction of UPR and cell death.

ER stress and activation of the UPR may contribute to triggering an exclusive type of death known as NETosis (Neutrophils Extracelular Traps) [16]. NETosis was first reported in 2004 and it has been gaining evidence as a last attempt of the cell to kill the invading microorganisms [16]. NETs are formed of DNA, histones and granules $[55 ; 56]$ and are projected onto the microorganism. This type of cell death depends on the activation of NADPH oxidase [57] and therefore the production of ROS. When DPI is used NETosis is inhibited [57; 58; 59]. The complete mechanism of how NETs are formed is unknown but they may involve the ER. NADPH oxidase triggered ER stress in neutrophil-like cells could be a mechanism by which ROS lead to NETs formation.

Chronic hyperglycemia is known to induce ROS production in many cell types, but failed to increase ROS levels to cause ER stress in dHL60 cells. This is likely explained by glucose transporters (GLUTs) expression in these cells. Neutrophils and dHL60 express GLUT 1 exclusively [38; 49; 60; 61], which has a low $\mathrm{Km}$ and gets saturated such that glucose transport does not increase despite high extracellular levels. It prevents the exposure of the cell to glucotoxicity. GLUT 2 presents a unique high $\mathrm{Km}$ for glucose $(\sim 17 \mathrm{mM})$, so the higher the concentration of glucose in the extracellular media, the higher the transport of glucose into the cell [61]. Pancreatic $\beta$-cells respond to high glucose concentration by producing and secreting more insulin. So, hyperglycemia overloads the ER and leads it to a stress condition $[36 ; 61 ; 62]$.

In summary, ROS produced by NADPH oxidase induce ER stress by PERK and IRE1 pathways in dHL60 cells, and this process is independent of calcium mobilization. Knowledge of the redox state and UPR activation may lead to better understanding of functions of neutrophils, such as phagocytosis, cytokines and chemokines production, NADPH oxidase complex per se and cell death process. 


\section{Acknowledgements}

The authors are indebted to the constant support ofDr. Sergio Grinstein, Hospital for Sick Children, Toronto, Canada. This research was funded by Fundação de Amparo a Pesquisa do Estado de São Paulo (FAPESP).

\section{$\underline{\text { References }}$}

[1] Cassatella MA (1999) Neutrophil-derived proteins: selling cytokines by the pound. Adv Immunol 1999 ; $73: 369-509$.

[2] Rossi F, Zatti M (1964) Biochemical aspects of phagocytosis in polymorphonuclear leucocytes. NADH and NADPH oxidation by the granules of resting and phagocytizing cells. Experientia 20(1): 21-23.

[3] Babior BM, Kipnes RS, Curnutte JT (1973) Biological defense mechanisms: the production by leukocytes of superoxide, a potential bactericidal agent. J Clin Invest 52: 741-744.

[4] Fantone JC, Ward PA (1982) Role of oxygen-derived free radicals and metabolites in leukocytedependent inflammatory reactions. Am J Pathol 107: 397-418.

[5] Savill J \& Haslett C (1995) Granulocyte clearance by apoptosis in the resolution of inflammation. Semin Cell Biol 6(6): 385-393.

[6] López-García P, Moreira D (2006) Selective forces for the origin of the eukaryotic nucleus. Bioessays 28(5):525-533.

[7] Lai E, Teodoro T, Volchuk A (2007) Endoplasmic reticulum stress: signaling the unfolded protein response. Physiology (Bethesda) 22:193-201.

[8] Rutkowski DT, Hegde RS (2010) Regulation of basal cellular physiology by the homeostatic unfolded protein response. J Cell Biol 189(5): 783-794.

[9] Tabas I, Ron D (2011) Integrating the mechanisms of apoptosis induced by endoplasmic reticulum stress. Nat Cell Biol 3: 184-90.

[10] Ron D, Walter P (2007) Signal integration in the endoplasmic reticulum unfolded protein response. Nat Rev Mol Cell Bio 8(7): 519-29.

[11] Wiseman RL, Haynes CM, Ron D (2010) SnapShot: The unfolded protein response. Cell 140(4): 590590.

[12] Bernales S, Papa FR, Walter P (2006) Intracellular signaling by the unfolded protein response. Annu Rev Cell Dev Biol 22: 487-508.

[13] Schroder M \& Kaufman RJ (2005) The mammalian unfolded protein response. Annu Rev Biochem 74: 739-789.

[14] Li G, Scull C, Ozcan L, Tabas I (2010) NADPH oxidase links endoplasmic reticulum stress, oxidative stress, and PKR activation to induce apoptosis. J Cell Biol 191(6):1113-1125.

[15] Santos CX, Tanaka LY, Wosniak J, Laurindo FR (2009) Mechanisms and implications of reactive oxygen species generation during the unfolded protein response: roles of endoplasmic reticulum oxidoreductases, mitochondrial electron transport, and NADPH oxidase. Antioxid Redox Signal $11: 2409-2427$.

[16] Brinkmann VU, Reichard C, Goosmann B, Fauler Y, Uhlemann DS, Weiss Y, Weinrauch A, Zychlinsky A (2004) Neutrophil extracellular traps kill bacteria. Science 303: 1532-1535.

[17] Chen K, Kirber MT, Xiao H, Yang Y, Keaney JF Jr (2008) Regulation of ROS signal transduction by NADPH oxidase 4 localization. J Cell Biol 181(7): 1129-1139.

[18] Babior BM, Curnutte JT, Kipnes RS (1975) Biological defense mechanisms. Evidence for the participation of superoxide in bacterial killing by xanthine oxidase. J Lab Clin Med 85: 235-244.

[19] Parkos, CA, Allen RA, Cochraine CG, Jesaitis AJ (1987) Purified cytochrome b from human granulocyte plasma membrane is comprised of two polypeptides with relative molecular weights of 91,000 and 22,000. J Clin Invest 80(3): 732-742.

[20] Han C, Freeman JL, Lee T, Motalebi SA, Lambeth JD (1998) Regulation of the neutrophil respiratory burst oxidase. Identification of an activation domain in p67(phox). J Biol Chem 273(27): 16663-16668.

[21] Nisimoto, Y, Motalebi S, Han CH, Lambeth JD (1999) The p67(phox) activation domain regulates electron flow from NADPH to flavin in flavocytochrome b(558). J Biol Chem 274(33): 22999-30005. 
[22] Babior BM (1991) The respiratory burst oxidase and the molecular basis of chronic granulomatous disease. Am J Hematol 37(4): 263-266.

[23] Klebanoff SJ (1968) Myeloperoxidase-halide-hydrogen peroxide anti-bacterial system. J Bacteriol 95(6): 2131-2138.

[24] Imlay JA, Linn S (1986) Bimodal pattern of killing of DNA-repair-defective or anoxically grown Escherichia coli by hydrogen peroxide. J Bacteriol, 166(2): 519-527.

[25] Klebanoff SJ (1992) Phagocytic cells: products of oxygen metabolism. In: Gallin JI, Goldstein IM Snyderman R, editors, Inflammation: Basic principles and clinical correlates. New York: NY Raven, p. 451.

[26] Kettle AJ, Winterbourn CC (1997) Myeloperoxidase: a key regulator of neutrophil oxidant production. Redox Rep 3: 3.

[27] Agner K (1972) Biological effects of hypochlorous acid formed by "MPO"-peroxidation in the presence of chloride ions. In: Akeson A \& Ehrenberg A, editors, Structure and Function of Oxidation Reduction Enzymes. New York, NY.: Pergamon, pp. 329-335.

[28] Harrison JE, Shultz J (1976) Studies on the chlorinating activity ofmyeloperoxidase. J Biol Chem 251(5): 1371-1375.

[29] Iyer GYN, Islam MF, Quastel JH (1961) Biochemical aspects of pathogenesis. Nature 192: 535-541.

[30] Domigan NM, Charlton TS, Duncan MW, Winterbourn CC, Kettke AJ (1995) Chlorination of tyrosyl residues in peptides by myeloperoxidase and human neutrophils. J Biol Chem 270(28): 16542-16548.

[31] Santos CX, Nabeebaccus AA, Shah AM, Camargo LL, Filho SV, Lopes LR (2013) Endoplasmic Reticulum Stress and Nox-Mediated Reactive Oxygen Species Signaling in the Peripheral Vasculature: Potential Role in Hypertension. Antioxid Redox Signal "In Press".

[32] Wu RF, Ma Z, Liu Z, Terada LS (2010) Nox4-derived H2O2 mediates endoplasmic reticulum signaling through local Ras activation. Mol Cell Biol 14:3553-68.

[33] MacDougall SL, Grinstein $\quad S$, Gelfand $\quad$ EW $\quad$ (1988) Activation of Ca2+dependent $\mathrm{K}+$ channels in human B lymphocytes by anti-immunoglobulin. J Clin Invest 81(2):449-454.

[34] Collins SJ (1987) The HL-60 promyelocytic leukemia cell line: proliferation, differentiation, and cellular oncogene expression. Blood 70(5): 1233-1244.

[35] Davis RC, Thomason AR, Fuller ML, Slovin JP, Chou CC, Chada S, Gatti RA, Salser WA (1987) mRNA species regulated during the differentiation of HL60 cells to macrophages and neutrophils. Dev Biol 119: 164-174.

[36] Henderson LM, Banting G, Chappell JB (1995) The arachidonate-activable, NADPH oxidaseassociated $\mathrm{H}+$ channel. Evidence that gp91-phox functions as an essential part of the channel. J. Biol. Chem. 270,5909-5916.

[37] Paclet MH, Henderson LM, Campion Y, Morel F, Dagher MC (2004) Localization of Nox2 N-terminus using polyclonal antipeptide antibodies. Biochem J 382: 981-6.

[38] Unger RH (1991) Diabetic hyperglycemia: link to impaired glucose transport in pancreatic beta cells. Science 8: 251:1200-12005.

[39] Liu W, Zhu X, Wang Q, Wang L (2013) Hyperglycemia induces endoplasmic reticulum stressdependent CHOP expression in osteoblasts. Exp Ther Med 5(5):1289-1292.

[40] Lakshmanan AP, Harima M, Suzuki K, Soetikno V, Nagata M, Nakamura T, Takahashi T, Sone H, Kawachi H, Watanabe K (2013)The hyperglycemia stimulated myocardial endoplasmic reticulum (ER) stress contributes to diabetic cardiomyopathy in the transgenic non-obese type 2 diabetic rats: a differential role of unfolded protein response (UPR) signaling proteins. Int $\mathrm{J}$ Biochem Cell Biol 45(2):438-447.

[41] Sage AT, Holtby-Ottenhof S, Shi Y, Damjanovic S, Sharma AM, Werstuck GH (2012) Metabolic syndrome and acute hyperglycemia are associated with endoplasmic reticulum stress in human mononuclear cells. Obesity (Silver Spring) 20(4):748-755.

[42] Walrand S, Valeix S, Rodriguez C, Ligot P, Chassagne J, Vasson MP (2003) Flow cytometry study of polymorphonuclear neutrophil oxidative burst: a comparison of three fluorescent probes. Clin Chim Acta 331: 103-10.

[43] Ellis JA, Mayer SJ, Jones OT (1988) The effect of the NADPH oxidase inhibitor diphenyleneiodonium on aerobic and anaerobic microbicidal activities of human neutrophils. Biochem J 251(3): 887-91.

[44] Lin C, Wang $\mathrm{H}$ (2012) NADPH oxidase is involved in $\mathrm{H} 2 \mathrm{O} 2$-induced differentiation of human promyelocytic leukaemia HL-60 cells. Cell Biol Int 36(4):391-395.

[45] Shimizu Y, Hendershot LM (2009) Oxidative folding: cellular strategies for dealing with the resultant equimolar production of reactive oxygen species. Antioxid Redox Signal 11(9): 2317-31.

[46] Kass GE, Orrenius S (1999) Calcium signaling and cytotoxicity. Environ Health Perspect 107 Suppl 1: 25-35. 
[47] Lückhoff A (1986) Measuring cytosolic free calcium concentration in endothelial cells with indo-1: the pitfall of using the ratio of two fluorescence intensities recorded at different wavelengths. Cell Calcium 7(4): 233-248.

[48] Mantovani A, Cassatella MA, Costantini C, Jaillon S (2011) Neutrophils in the activation and regulation of innate and adaptive immunity Nat Rev Immunol $11: 519-531$.

[49] Ahmed N, BerridgeMV(1999) N-glycosylation of glucose transporter-1 (Glut-1) is associated with increased transporter affinity for glucose in human leukemic cells. Leuk Res 4: 395-401.

[50] Coe H, Michalak M (2009) Calcium binding chaperones of the endoplasmic reticulum. Gen PhysiolBiophys 28: 96-103.

[51] Lytton J, Westlin M, Hanley MR (1991) Thapsigargin inhibits the sarcoplasmic or endoplasmic reticulum Ca2+-ATPase family of calcium pumps. J BiolChem 266: 17067-17071.

[52] Li MQ, Baumeister P, Roy B, Phan T, Foti D, Luo SZ, Lee AS (2000) ATF6 as a transcription activator of the endoplasmic reticulum stress element: thapsigargin stress-induced changes and synergistic interactions with NF-Y and YY1. Mol Cell Biol 20: 5096-5106.

[53] Miyake H, Hara I, Arakawa S, Kamidono S (2000) Stress protein GRP78 prevents apoptosis induced by calcium ionophore, ionomycin, but not by glycosylation inhibitor, tunicamycin, in human prostate cancer cells. J Cell Biochem 77: 396-408.

[54] Bréchard S, Bueb JL, Tschirhart EJ (2005) Interleukin-8 primes oxidative burst in neutrophil-like HL-60 through changes in cytosolic calcium. Cell Calcium37(6):531-40.

[55] Jaillon SG, Peri Y, Delneste I, Fre'maux A, Doni F, Moalli C, Garlanda L, Romani H, Gascan S, Bellocchio (2007). The humoral pattern recognition receptor PTX3 is stored in neutrophil granules and localizes in extracellular traps. J Exp Med 204: 793-804.

[56] Urban, CF, Ermert D, Schmid M, Abu-Abed U, Goosmann C, Nacken W, Brinkmann V, Jungblut PR, Zychlinsky A (2009) Neutrophil extracellular traps contain calprotectin, a cytosolic protein complex involved in host defense against Candida albicans. PLoS Pathog. 5: e1000639.

[57] Gray RD, Lucas CD, Mackellar A, Li F, Hiersemenzel K, Haslett C, Davidson DJ, Rossi AG (2013). Activation of conventional protein kinase $C(P K C)$ is critical in the generation of human neutrophil extracellular traps. J Inflamm 10(1) : 12.

[58] Fuchs TA, Abed U, Goosmann C, Hurwitz R, Schulze I, Wahn V, Weinrauch Y, Brinkmann V, Zychlinsky A (2007) Novel cell death program leads to neutrophil extracellular traps. J Cell Biol 176: 231-241.

[59] Lim MB, Kuiper JW, Katchky A, Goldberg H, Glogauer M (2011) Rac2 is required for the formation of neutrophil extracellular traps. J Leukoc Biol 90: 771-776.

[60] Schuster DP, Brody SL, Zhou Z, Bernstein M, Arch R, Link D, Mueckler M (2007) Regulation of lipopolysaccharide-induced increases in neutrophil glucose uptake. Am J Physiol Lung Cell Mol Physiol 292(4): 845-851.

[61]Thorens B, Mueckler M (2010) Glucose transporters in the 21st Century. Am J PhysiolEndocrinolMetab 298(2).

[62] Back SH, Kaufman RJ (2012) Endoplasmic reticulum stress and type 2 diabetes. Annu Rev Biochem 81: 767-93. 


\section{Figure Legends}

Figure 1. Effect of Hyperglycemia (A) and PMA (B) on ROS production. HL60 cells were differentiated into neutrophil-like cells (dHL60) with 1.25\% DMSO for 6 days. Cells were stimulated or not with PMA $(1 \mu \mathrm{M})$. DPI (10 um), a NADPH oxidase inhibitor, was used as a negative control. After $24 \mathrm{~h}$ treatment with normoglycemic media $(5.5 \mathrm{mM})$, hyperglycemic media $(25 \mathrm{mM})$ and mannitol $(5.5 \mathrm{mM}$ of glucose $+19.5 \mathrm{mM}$ of mannitol), dHL60 cells were marked with DHR $(10 \mu \mathrm{M})$ stimulated with PMA and evaluated by flow cytometry. Graph represents the median of fluorescence \pm s.e.m. Results are from 6 independent experiments. $\left({ }^{* * *}\right)$ Indicate $p<0.001$.

Figure 2. Effects of PMA (A), fMLP (B-D) on calcium influx and ER calcium content $(\mathrm{E}, \mathrm{F}) . \mathrm{HL} 60$ cells were differentiated into neutrophil-like cells (dHL60) with 1.25\% DMSO for 6 days. After $24 \mathrm{~h}$ treatment with normoglycemic media $(5.5 \mathrm{mM})$, hyperglycemic media $(25 \mathrm{mM})$ and mannitol $(5.5 \mathrm{mM}$ of glucose $+19.5 \mathrm{mM}$ of mannitol), cells were marked with Indo-1 and fluorescence was detected by fluorometry. Graph represents the intensity of fluorescence during the time of analysis $(A, C)$ and Graph bars show the mean of intracellular calcium concentration \pm s.e.m. $(B, D)$. Results are from 4 independent experiments. $\left({ }^{* *}\right.$ Indicate $p<0.01$ and $\left({ }^{*}\right)$ indicate $p<0,05$.

Figure 3. Effect of PMA and DPI inhibitor on ER stress markers: (A) p-elF2a; (B)sXBP1. HL60 cells were differentiated into neutrophil (dHL60) with 1.25\% DMSO for 6 days. Cells were stimulated with PMA $(1 \mu \mathrm{M})$ for 1 or $4 \mathrm{~h}$. DPI $(10 \mu \mathrm{m})$ was used as an inhibitor of ROS production for $1 \mathrm{~h}$ and $4 \mathrm{~h}$. (A) Graph represents the mean \pm s.e.m. of the Optical Density (OD) of the protein bands. (B) Figure represents the complementary cDNA bands of XBP1 and sXBP1. Results are from 3 independent experiments. (C) Control (dHL60 without any stimulus). (D1H) dHL60 + 1h [PMA + DPI]. (P1H) dHL60 + 1h PMA. (D4h) $\mathrm{dHL60}+4 \mathrm{~h}[\mathrm{PMA}+\mathrm{DPI}] .(\mathrm{P} 4 \mathrm{H}) \mathrm{dHL60}+4 \mathrm{~h}$ PMA. $\left({ }^{* * *}\right)$ Indicates $p<0.001$.

Figure 4. Effect of HG+PMA on ER stress markers: (A) p-elF2a; (B)sXBP1. HL60 cells were differentiated into neutrophil (dHL60) with 1.25\% DMSO for 6 days. After $24 \mathrm{~h}$ treatment with normoglycemic media $(5.5 \mathrm{mM})$, hyperglycemic media $(25 \mathrm{mM})$ and mannitol $(5.5 \mathrm{mM}$ of glucose $+19.5 \mathrm{mM}$ of mannitol), cells were stimulated with PMA $(1 \mu \mathrm{M})$ for 1 or $4 \mathrm{~h}$. (A) Graph represents the mean \pm s.e.m. of the Optical Density (OD) of the protein bands. (B) Figure represents the complementary CDNA bands of XBP1 and sXBP1. Results are from 3 independent experiments.. NG (normoglicemic), MN (Manitol), HG (Hiperglicemic) (N1h) dHL60 NG + 1h PMA. (M1h) dHL60 MN + 1h PMA. (H1h) dHL60 HG + 1h PMA. (N4h) dHL60 NG + 4h PMA. (M4h) dHL60 MN + 4h PMA. (H4h) dHL60 HG + 4h PMA. $\left({ }^{* * *}\right)$ Indicates $p<0.001$. 

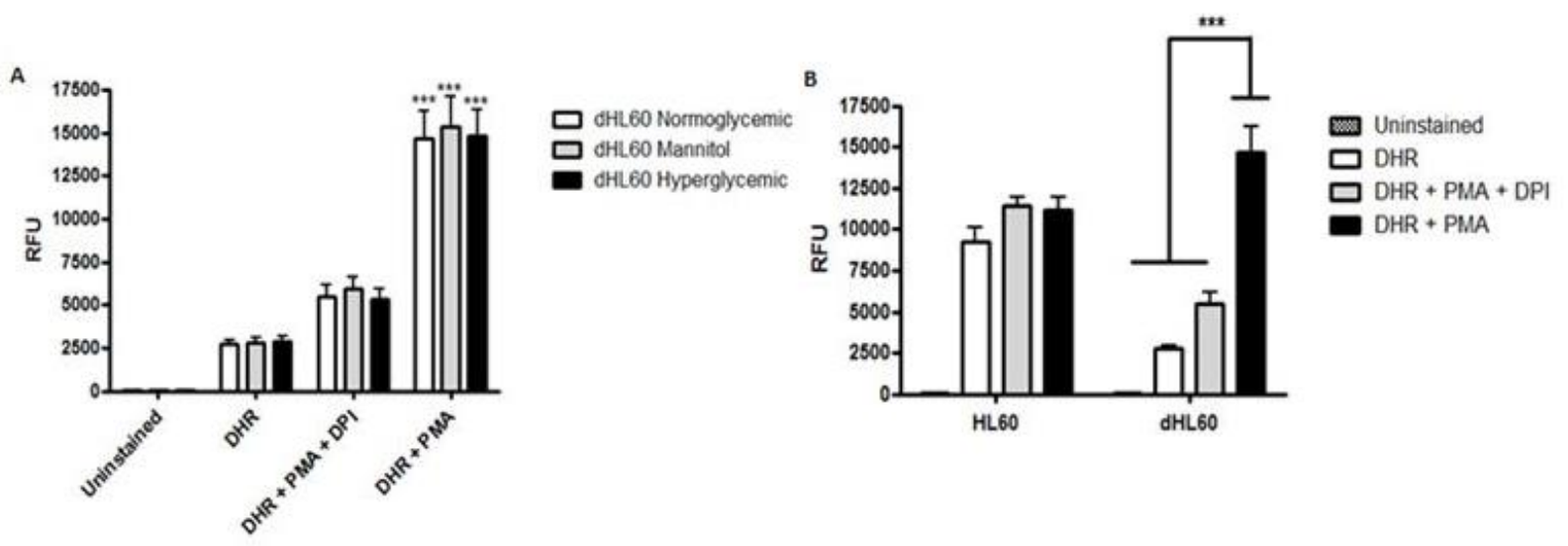

Figure 1. Effect of Hyperglycemia (A) and PMA (B) on ROS production.

A
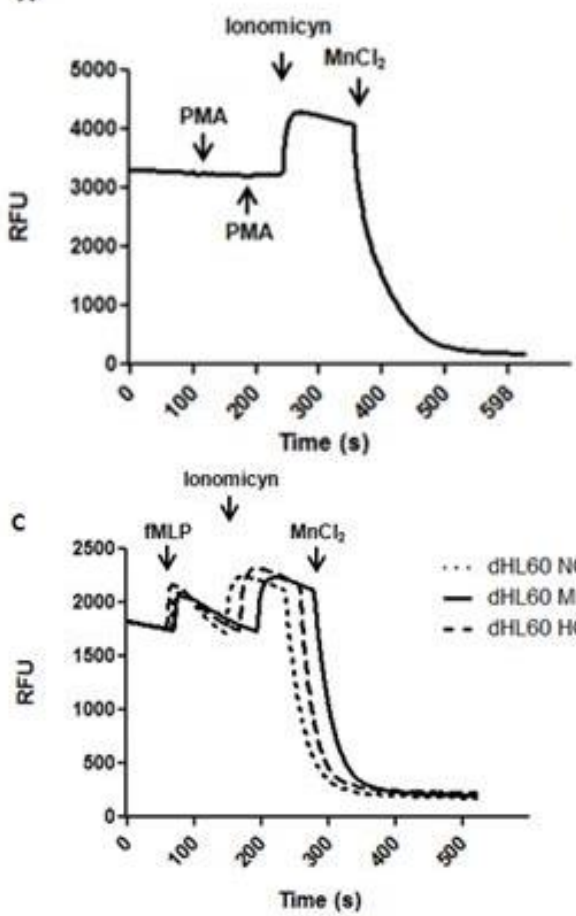

E

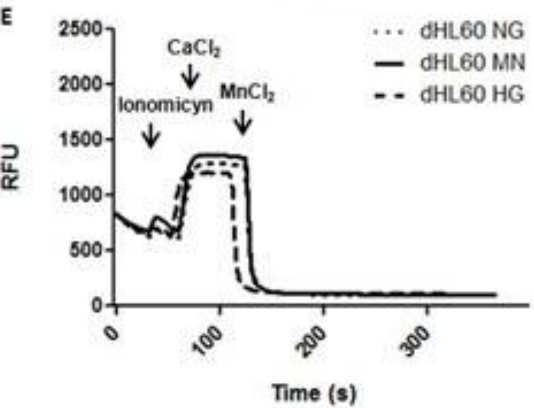

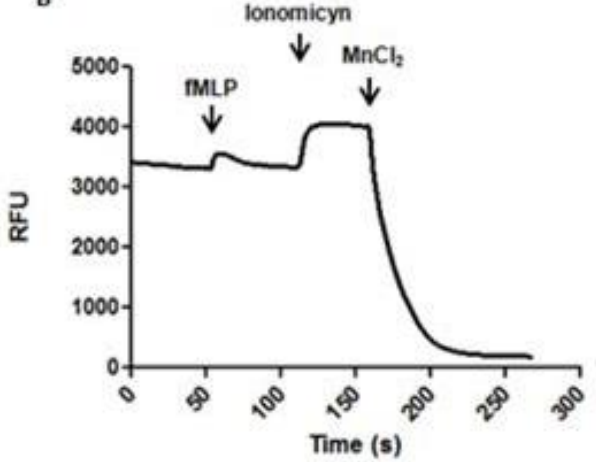

D
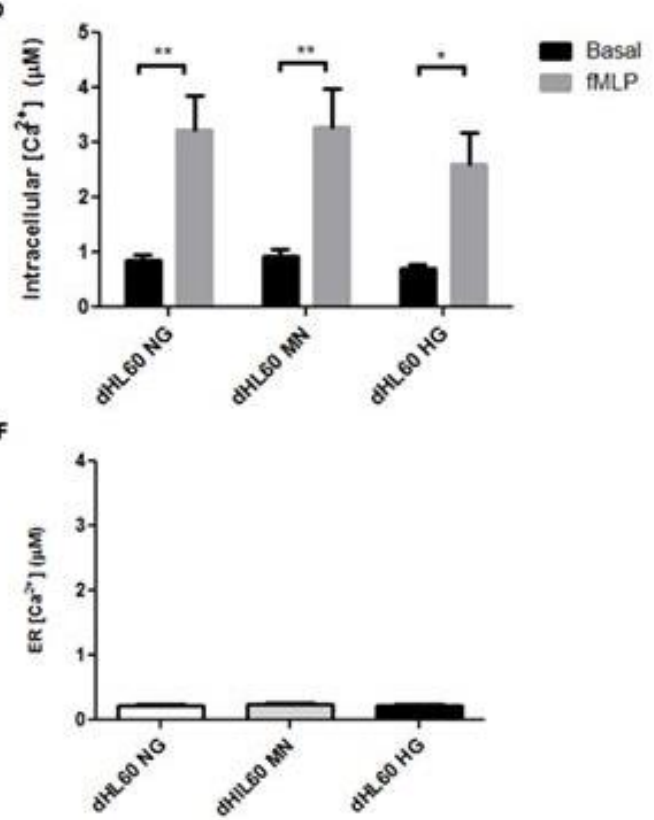

Figure 2. Effects of PMA (A), fMLP (B-D) on calcium influx and ER calcium content $(E, F)$. 
A
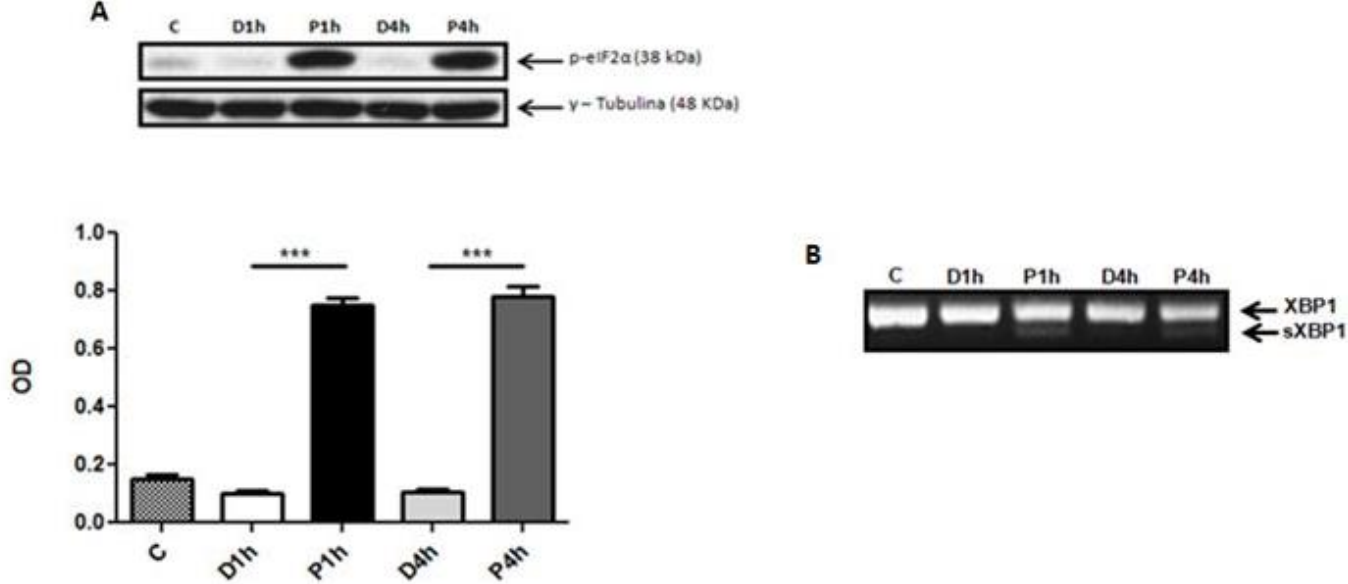

Figure 3. Effect of PMA and DPI inhibitor on ER stress markers: (A) p-elF2 $\alpha$; (B)sXBP1.

A
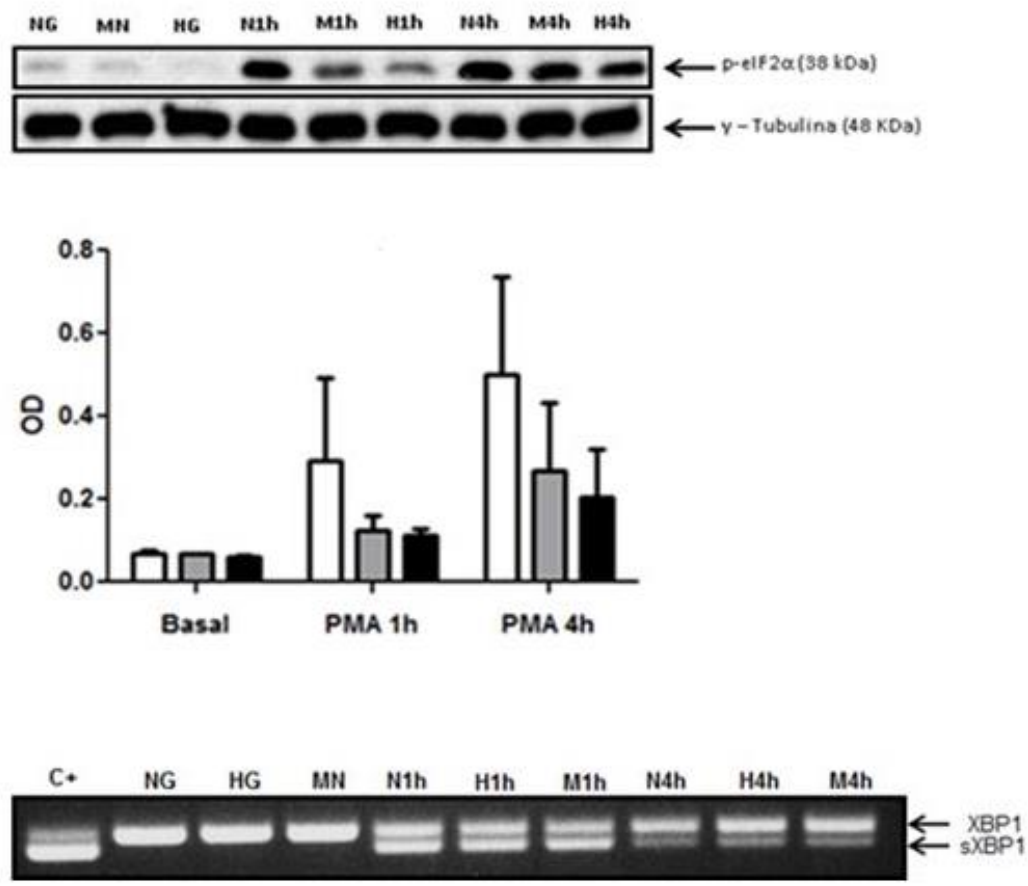

Figure 4. Effect of HG+PMA on ER stress markers: (A) p-elF2 $\alpha$; (B)sXBP1. 